\title{
NCAA Division I student athlete characteristics as indicators of academic achievement and graduation from college
}

\author{
Bradley David Ridpath \\ West Virginia University
}

Follow this and additional works at: https://researchrepository.wvu.edu/etd

\section{Recommended Citation}

Ridpath, Bradley David, "NCAA Division I student athlete characteristics as indicators of academic achievement and graduation from college" (2002). Graduate Theses, Dissertations, and Problem Reports. 2428.

https://researchrepository.wvu.edu/etd/2428

This Dissertation is protected by copyright and/or related rights. It has been brought to you by the The Research Repository @ WVU with permission from the rights-holder(s). You are free to use this Dissertation in any way that is permitted by the copyright and related rights legislation that applies to your use. For other uses you must obtain permission from the rights-holder(s) directly, unless additional rights are indicated by a Creative Commons license in the record and/ or on the work itself. This Dissertation has been accepted for inclusion in WVU Graduate Theses, Dissertations, and Problem Reports collection by an authorized administrator of The Research Repository @ WVU.

For more information, please contact researchrepository@mail.wvu.edu. 
NCAA Division I Student Athlete Characteristics as Indicators of Academic Achievement and Graduation from College

\author{
Bradley David Ridpath
}
Dissertation submitted to
The College of Human Resources and Education of
West Virginia University
In partial fulfillment of the requirements
For the degree of

\author{
Doctor of Education \\ In \\ Educational Leadership \\ Committee Chair: Teresa Eagle, Ed.D. \\ Paul Leary, Ed.D. \\ Ernest Goeres, Ph.D. \\ John Kiger, Re.D. \\ Donnalee Cockrille, Ed.D. \\ Department of Educational Leadership
}

Morgantown, West Virginia

2002

Keywords: Athletics, Eligibility, Graduation

Copyright 2002 Bradley David Ridpath 


\begin{abstract}
NCAA Division I Student Athlete Characteristics as Indicators of Academic Achievement and Graduation from College
\end{abstract}

\title{
Bradley David Ridpath
}

The purpose of this study was to determine if NCAA Division I student athlete characteristics of graduation, presented in the literature and previous research, can be generalized to student athletes in the Mid-American Conference using research based conclusions developed from this study. The study identified seven characteristics prominent in the literature and made conclusions to ascertain if information provided on the characteristics, as presented in the literature, can be generalized to the Mid-American Conference. The research population for this study was $\mathrm{N}=1430$. The population represented student athletes at the 13 schools of the MidAmerican Conference. All student athletes represented in the selected population were seniors by NCAA eligibility standards and were within one academic year of receiving a baccalaureate degree. The researcher selected a proportional stratified sample $(25 \%)$ of the population $(\mathrm{n}=358)$ and mailed a research-developed survey instrument, inspired by previous survey instruments and research, to the selected proportion of the population. Data were stored securely and complete anonymity was guaranteed. The analysis of the data indicated that information gleaned from the literature can be applied to student athletes in the Mid-American Conference based upon the research conclusions presented in this study. The characteristics of graduation prominently identified in the literature that formed the basis for this study were student athletes' perception of college coaches' emphasis on academics, the extent of use of specialized academic support services for student athletes, specific sport played in college, ethnicity, gender, NCAA high school core course grade point average, and score attained on SAT or ACT test. The analysis of the data specific to the student athletes in the Mid-American Conference revealed, as in the literature, that the constructs of gender, ethnicity, and sport played can have a significant impact on the academic achievement in the other listed categories and on potential for graduation. Ancillary findings were related to the academic achievement of Caucasian females and women basketball players in the conference. 


\section{ACKNOWLEDGEMENTS}

It is very tough to put into words the thanks to so many people who supported me on this project. This dissertation is not only a product of my personal efforts, but it is the product of a team of people probably too numerous to mention. I will, however, try in some way to thank as many people as I can who have helped me since I began this quest in 1998 and who have also helped me through some trying and difficult professional and personal times. From being silly enough to start a doctoral program when my wife was pregnant, through the birth of another child, a career that required almost eight days a week -- twenty-five hours a day attention, a very public NCAA major infractions investigation, to starting a new job, and through all the day-today pressures of life -- I made it, or it is better said, "we made it." This list is a small token of my appreciation, and I truly apologize if I forgot anyone.

Dr. Teresa Eagle: My Committee Chair and my friend. How she kept from wringing my neck sometimes I will never know. Her patient guidance, sage advice, and encouragement kept me going throughout a turbulent four years, and I thank her for putting up with me.

Dr. Paul Leary: The first faculty member I met in the program, and I have been entertained ever since. From teasing him about the Red Sox to smiling inside every time I heard the phrases, "trenchant observation," or "let the literature talk to you." It has been a joy to learn from him, and I look forward to continuing our sports talks and friendship in the future. 
Dr. John Kiger: I have many miles with this guy. I picked him for the committee because he is simply the best academician I have ever met. His assistance as my minor chair was invaluable over the years, and our mutual interest in the integrity of intercollegiate athletics will no doubt lead to future collaborations. I appreciate your friendship and advice John -- from a real admirer.

Dr. Ernie Goeres: One regret is that I have not met Ernie in person; however, I feel like I have known him for years. His attention to this project, despite being located in Morgantown, and me has been excellent. I look forward to one day meeting Ernie and trading Dr. Leary stories.

Dr. Dee Cockrille: An administrator that I miss, and I know Marshall University misses. A true person of integrity, who cares about the welfare of all students. I appreciate all of her help, and I know she is a person I can call when I am in need of anything, anytime.

Dr. Karen Kirtley: I am going miss our drives to Charleston and our talks, or should I say my talks. I know it is hard to have a conversation with me because I blab on and on, but I enjoyed listening to you when I let you talk (HA HA). Seriously, I have enjoyed our friendship, and I know it will continue even though we are "finally" done with the program.

Dr. Norma Thompson: Our inspiration. The only person I know that works harder than me. She finished this program in almost record time. Pretty good for someone with two jobs and a family!! I knew I could never complain because Norma had it worse and she worked twice as hard. Karen and I missed you greatly when you finished the program. 
Carol Fugitt, Rhonda Sheppard, Jim Hodge, Joy Cowdery, Dan Huck, Robin Walton, Michelle Duncan, Nancy Dunn, Doug Sturgeon, Darrell Taylor, Becky Goodwin, Kevin Smith, Dennis Blatt, Bobbie (Babs) McDermott, Tammy Johnson and the rest of the faculty (especially Dr. Prisk) and my classmates of the cooperative program -- classmates and instructors who seemed as interested in my projects as their own. I enjoyed the classes and program immensely because of the people and wonderful teaching and I will miss the camraderie.

My friends in the Mid-American Conference, Kevin Porter, Kevin Klotz, Jennifer Stiles, Holly Baumgartner, Bob Heller, Ken Peters, Sid Sink, Chris Peacock, Melody Reifel, Derek Van der Merwe, Jeff Stone, Bobbie Cesarek, Steve Flippen, Dave Land, Charlie Donnor and Bill Maher - the real workhorses behind this project who insured that the survey instrument was distributed and returned to me in a timely fashion. Without your efforts, there would be no project. I knew I could count on you as I did for four years as your colleague. I truly miss our interaction and times together. I felt like a complete fool being a member of this group because it consisted of some of the finest people I have ever met, and sometimes I just did not feel worthy. I appreciate your help with anything I ever asked for, but most of all I appreciate your friendship and loyalty to me during some very tough, public times. I hope one day we will have the chance to work together again.

Jacqueline, Chiara, and Bradley II --What can you say about a woman who supports her husband as he leaves a financially stable career for the unknowns of starting over to pursue something he loves? What can you say about a woman who has to support her husband so he can finish graduate school? What can you say about a woman who leaves her family and country to support 
her husband through poverty pay level internships and jobs so he can realize his dream of working in intercollegiate athletics? What can you say about a woman with two children and a household to run who supports her husband while he is working full time, teaching classes, and trying to complete a doctorate? You simply cannot say enough to a person who puts their life on hold so you can realize your own dreams. Sweetie, you will never know how much I appreciate you and love you for all you have done for me, because it is impossible to do it that much. So I hope a simple "thank you" and "I love you" will do.

To my children, I am so glad that you are probably too young to remember the trying times of this program and of my professional life. I know I have spent a lot of time away working on bettering life for our family. I now need to spend more time with you. I am just glad I have some new-found time to be a daddy and hope I can be the best daddy in the world to you.

This dissertation is dedicated to Jacqueline, Chiara, and Bradley Ridpath II. 


\section{TABLE OF CONTENTS}

$\underline{\text { Page }}$



ACKNOWLEDGEMENTS ............................................................

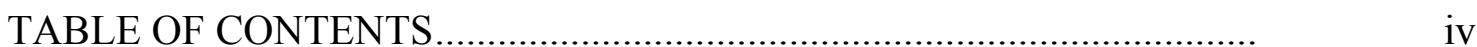

LIST OF TABLES ........................................................................

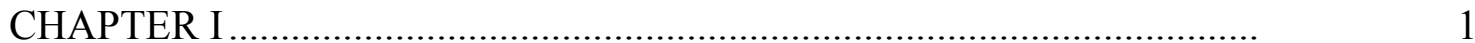

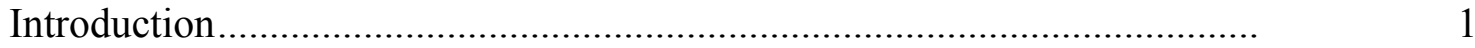

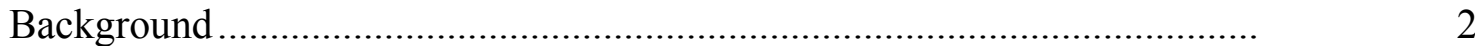

History of Intercollegiate Athletics and the NCAA..................................... 3

History of Student Athlete Academic Eligibility Standards ........................

Predictors of Student Athlete Graduation Rates from the Literature..............

Student Athlete's Perception of College Coach's Emphasis on Academics . 8

The Use of Specialized Academic Support Services for Student Athletes....

Specific Sport Played in College ....................................................................

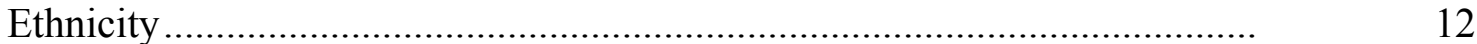

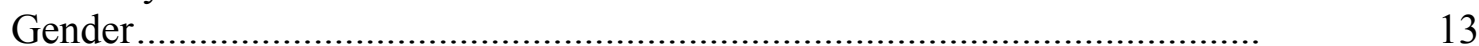

High School Core-Course Grade Point Average .........................................

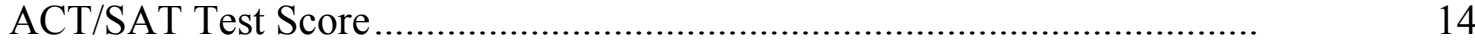

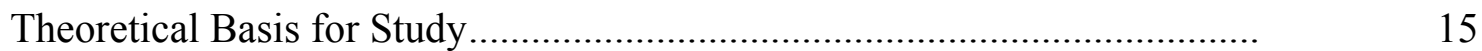

Statement of Problem..........................................................................

Research Question .........................................................................

Operational Definitions.......................................................................

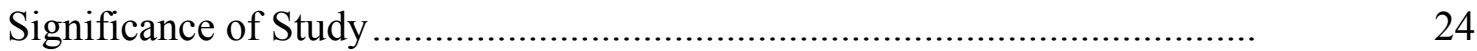

Limitations and Assumptions ........................................................ 26

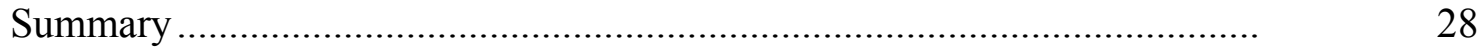




\section{TABLE OF CONTENTS}

$\underline{\text { Page }}$

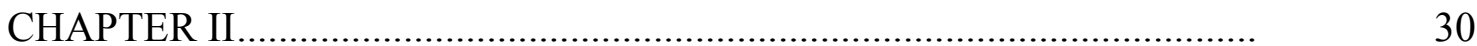

Review of Literature, Introduction to Intercollegiate Athletics....................... 34



The Beginning of Academic and Eligibility Regulations in the NCAA.........

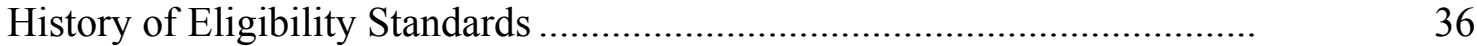

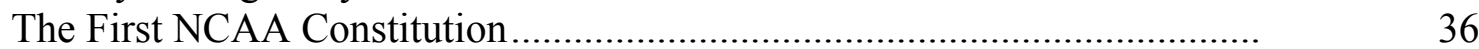

The Development of National Initial and Continuing Eligibility Standards . $\quad 40$

Proposition 48 .................................................................................



History of Tracking Graduation Rates of NCAA Division I Student Athletes 49

Previous Research on Graduation Rates of NCAA Division I Student Athletes 52

Other Student Athlete Graduation Rate Research ........................................

Predictors of Student Athlete Graduation Rates ............................................

Student Athletes Perception of College Coach's Emphasis of Academics ...

The Use of Specialized Academic Support Services for Student Athletes.... $\quad 57$

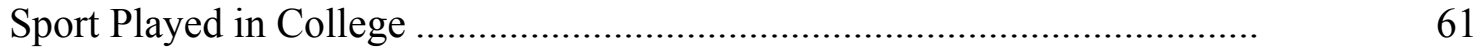

Examples of Sport Played in College Affecting Graduation Rates ................ 64

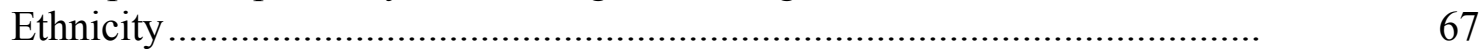

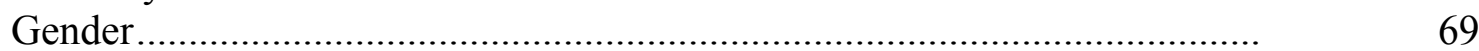

High School Core-Course Grade Point Average ............................................

ACT/SAT Test Score ............................................................................

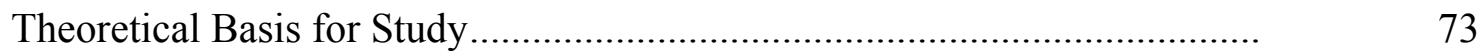

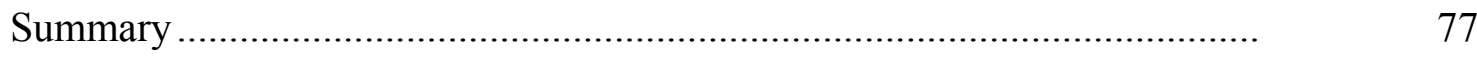

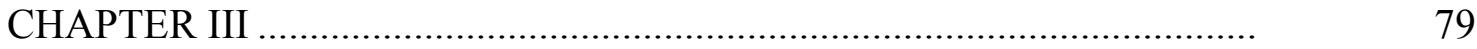

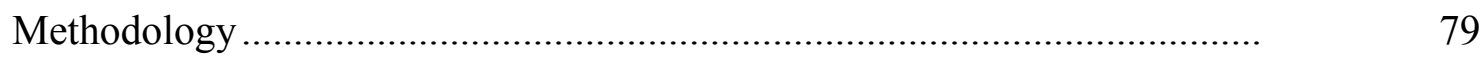

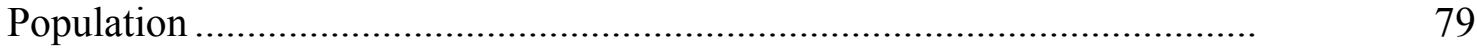

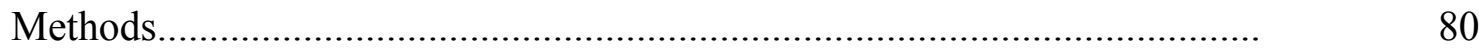

Sample

viii 


\section{TABLE OF CONTENTS}

$\underline{\text { Page }}$

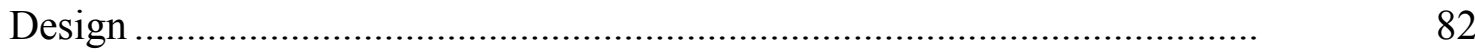

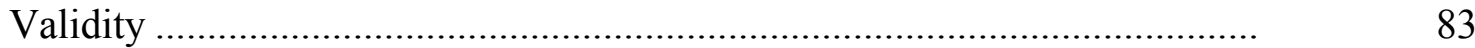

Data Analysis ..............................................................................

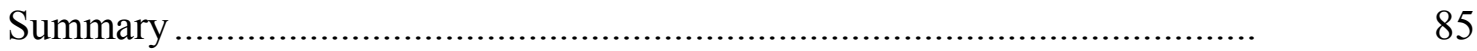

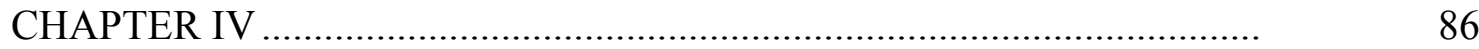



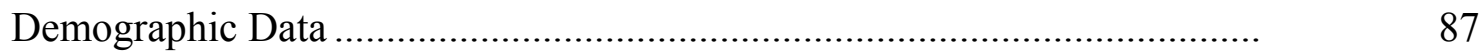

Major Findings ................................................................................

Student Athlete's Perception of College Coach's Emphasis on Academics . 89

The Extent of Use of Academic Support Services for Student Athletes .......

Specific Sport Played in College ..................................................................

Ethnicity .....................................................................................

Gender............................................................................... 101

NCAA Core-Course Grade Point Average ................................................

ACT/SAT Test Score .......................................................................... 104

Ancillary Findings ....................................................................

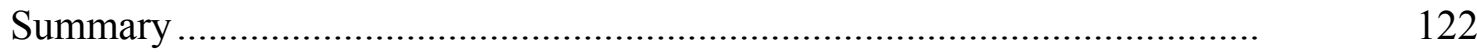

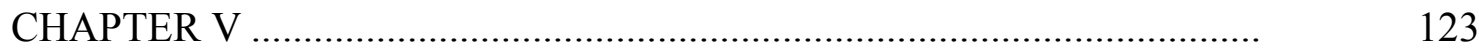

Summary of Study, Conclusions, and Recommendations ......................... 123

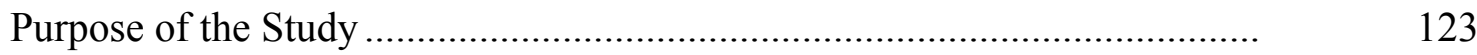

Summary of Procedures .................................................................

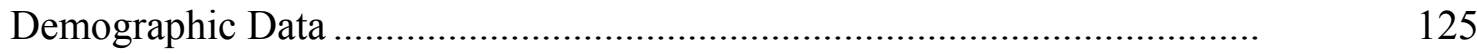

Summary of Findings and Conclusions ................................................. 125

Student Athlete's Perception of College Coach's Emphasis on Academics . 126

The Extent of Use of Academic Support Services for Student Athletes .......

Specific Sport Played in College .............................................................. 132 


\section{TABLE OF CONTENTS}

$\underline{\text { Page }}$

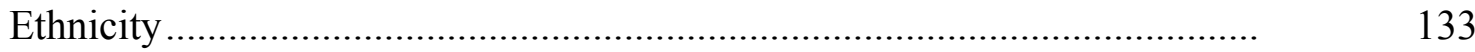

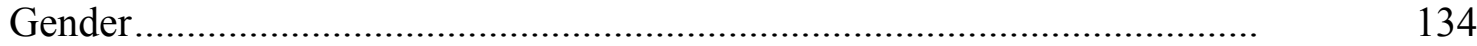

NCAA Core-Course Grade Point Average ...............................................

ACT/SAT Test Score ..........................................................................

Ancillary Findings ........................................................................ 138

Theoretical Basis...............................................................................

Discussion and Implications ............................................................. 145



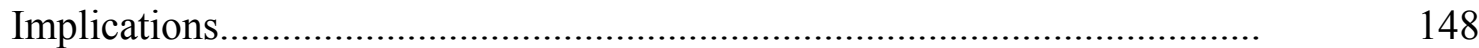

Limitations and Recommendations for Further Research ........................ 150

Limitations of This Research ...............................................................

Suggestions for Further Research ....................................................

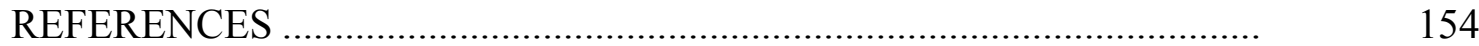



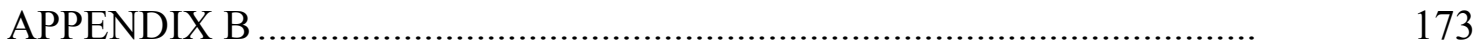

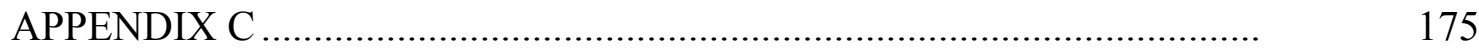

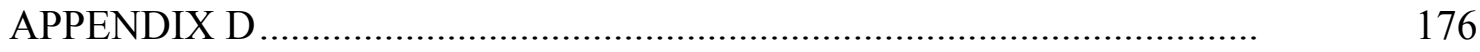

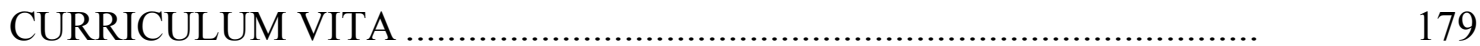




\section{LIST OF TABLES}

$\underline{\text { Table }}$

$\underline{\text { Page }}$

Table 1. College Coach's Emphasis on Academics, All Sports

Question 12

Table 2. College Coach's Emphasis on Academics, All Sports

Question 13

Table 3. College Coach's Emphasis on Academics, All Sports

Question 14 .

Table 4. College Coach's Emphasis on Academics, All Sports

Question 22

Table 5. College Coach's Emphasis on Academics, All Sports

Question 23

Table 6. Extent of Use of Specialized Academic Support Services for Student Athletes, Question 43............................................

Table 7. Extent of Use of Specialized Academic Support Services for Student Athletes, Question 45

Table 8. Extent of Use of Specialized Academic Support Services for Student Athletes, Question 46.

Table 9. Frequency Statistics on Completion of Survey by Sports .....

Table 10. Descriptive Statistics on Differences Between Selected Sports, Male and Female

Table 11. Frequency Statistics on Completion of Survey by Ethnicity .

Table 12. Frequency Statistics on Completion of Survey by Gender....

101

Table 13. Core-Course GPA Reported by All Sports

Table 14. ACT Test Score, Frequency Distribution, All Sports

Table 15. SAT Test Score, Frequency Distribution, All Sports

$106-107$

Table 16. Analysis of Variance, All Sports

108 


\section{LIST OF TABLES}

$\underline{\text { Table }}$

$\underline{\text { Page }}$

Table 17. Cross-Tabulation Use of Academic Services by Ethnicity, All Sports, Question 45

Table 18. Cross-Tabulation by Ethnicity, All Sports, Question 46 .......

110

Table 19. Cross-Tabulation by Gender, All Sports, Question 46 ...........

Table 20. Cross-Tabulation by Gender, All Sports, Question 46 .......... 112

Table 21. Group Statistics Men's Basketball Based on Ethnicity ......... $\quad 114$

Table 22. Group Statistics of Football Based on Ethnicity ...................

Table 23. One Way Analysis of Variance, Ethnicity Difference Between Groups ................................. 116

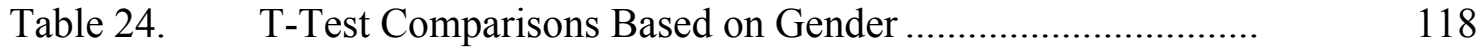

Table 25. Descriptive Data on Gender and Ethnicity Football, Men's and Women's Basketball

Table 26. One Way Analysis of Variance Based on Gender, Ethnicity, and Sport Played, All Sports.

Table 27. One Way Analysis of Variance Based on Gender, Ethnicity, and Sport Played Relating to ACT/SAT Test Score. 


\section{CHAPTER I}

Introduction

The phenomenon of intercollegiate student athletes' academic success and probability of graduation has been a cause of concern and the subject of significant inquiry by university and intercollegiate athletic administrators (Adler \& Adler, 1985; Briggs, 1997; Grimes \& Chressanths, 1994; Hanford, 1979; Pascarella, Bohr, Nora \& Terenzini, 1995). During the early 1980s, a great deal of controversy arose about the perceived lack of academic preparation and graduation from college of student athletes (Benson, 1994). Annual tracking and compiling of student athlete graduation rates then evolved as a measure of student athlete success or failure for National Collegiate Athletic Association (NCAA) member institutions and as the best indicator of student athlete academic success in college (McMillen, 1991; Snyder, 1996).

NCAA member institutions are required not only to report graduation rates of student athletes, but also to provide support to ensure the academic success of their student athletes as regulated by the NCAA (Howard-Hamilton \& Watt, 2001; McMillen, 1991; Urban, 2000). This study analyzes if predetermined characteristics that influence graduation from college for NCAA Division I student athletes, as described in the literature, can be generalized to a Division I athletic conference based on data gathered from student athletes in that conference. Information gathered for this study can be used as a catalyst to potentially increase the graduation rates of student athletes at NCAA Division I athletic conference. The particular Division I intercollegiate athletic conference selected for this study is the Mid-American Conference. The Mid-American Conference is an interesting conference to assess the literature and explore the generalizability of the research findings in that this conference is more likely to admit academic at risk student athletes than many of the other conferences in NCAA Division I (Messer \& Cherry, 2001) 


\section{Background}

Today, thousands of college students compete in intercollegiate athletics on varsity and sub-varsity (junior varsity) sports teams sponsored by the NCAA, or other national intercollegiate athletic governing bodies. The impetus to start tracking and publishing the graduation rates of student athletes at each Division I and II institution started in 1986 after new initial athletic eligibility rules for incoming freshman were put into effect on a nationwide basis (Benson, 1994, 1997; McMillen, 1991, Reyes, 1997). Since 1991, all NCAA Division I institutions have been required to report on an annual basis the graduation rate of all student athletes within a six-year period starting with initial enrollment (Benson, 1994; McMillen, 1991). This mandatory reporting requirement became federal law as part of the 1991 Campus Crime Act.

Many researchers, academicians, and administrators wanted to see what impact the new academic standards were having on the graduation rates of student athletes (Benson, 1994, 1997; McMillen, 1991, Reyes, 1997). This first federal action to force Division I and II colleges and universities to disclose their graduation rates began in 1988 by three former college and professional athletes. Senator Bill Bradley (Democrat-New Jersey), Representative Tom McMillen (Democrat-Maryland), and Representative Ed Towns (Democrat-New York) introduced the legislation later to be known as the "Student Athlete Right to Know Act" in 1988. The reason for introducing this legislation at the federal level was to require colleges and universities to report, and make public, information on the graduation status of Division I student athletes. According to McMillen (1991) several independent studies on the subject prior to the Student Athlete Right to Know Act stated the overall graduation rate of student athletes was poor overall. Most of the NCAA membership was against this legislation, but many in Congress, 
through committee and debate, supported the bill on the floor of the House and Senate (McMillen, 1991; Reyes, 1997). The Student Athlete Right to Know Act became law as part of the Campus Security Act of 1991. The legislation is officially known as 20 U.S.C. S. 1092 ("The Student Athlete," 1991). The law stated in part that disclosing the graduation rates of student athletes would make prospective students and student athletes aware of “...the educational commitments of an institution and would help prospective students and student athletes make an informed judgment about the educational benefits" (Knight, J.S. \& Knight, J.L., 1991, 1993; McMillen, 1991, “The Student Athlete,” 1991).

History of Intercollegiate Athletics and the NCAA

Intercollegiate athletics have been a part of higher education and university life since the early $18^{\text {th }}$ century, when athletics were made part of the curriculum at the Rugby School of England. Intercollegiate athletic competition in the United States is traced back as early as the 1820 s to football and rugby games between Ivy League schools like Harvard, Yale, and Princeton (Falla, 1981; Howard-Hamilton \& Watt, 2001; Zimbalist, 1999). The first documented and verified intercollegiate athletic contest was a football game between Princeton and Rutgers in 1869 (Falla, 1981; Funk, 1991; Howard-Hamilton \& Watt; 2001, Zimbalist, 1999). Later that same year, the faculties of the two schools canceled the following year's contest because they feared an over-emphasis on the game over academics and studying (Falla 1981; Funk, 1991, Zimbalist, 1999). By 1883, the now famous Harvard and Yale football game had been played several times.

To the disgust of both faculties, representatives of athletic interests (boosters) from both schools were trying to use this very popular contest to raise funds to acquire property to build their own football fields. The 1883 game, played at the Polo Grounds in New York City, drew 
over 10,000 fans and generated the money for the boosters to pay for the new fields. For the first time, intercollegiate sport began to dictate university policy and conflict with academia (Falla, 1981; Zimbalist, 1999).

Several attempts at organizing an intercollegiate athletics governing body were made until the official formation of the NCAA. On January 11, 1895, there was an historic meeting of the Intercollegiate Conference of Faculty Representatives, which later became the Big Ten Conference (Byers, 1995; Falla, 1981). This is the first intercollegiate conference on record that made regulations regarding student athletes' eligibility and participation. (Chu, Seagrave \& Becker, 1985; Wilson, 1967). Eligibility and participation rules began to resonate across the country through other college campuses, but many abuses of campus academic requirements still existed and more needed to be done. There were many pockets of compliance, but intercollegiate athletic abuses of academic standards needed to be addressed collectively by all higher education institutions at a national level (Falla, 1981).

It was in 1905 that a nationwide call for college football reform led to a more formal approach of a governing body for intercollegiate athletics. Collaboration of institutions for this reason was not started initially for academic or booster abuses, but for regulating the sport of college football on the field of play (Falla, 1981; Grimes \& Chressanths, 1994). The call for reform in the rules of the game came from President Teddy Roosevelt. In the eyes of many, college football, with its mass momentum formations and anything goes philosophy, had reached an unacceptable level of violent play. President Roosevelt used the prestige of his office to try to calm the fears of much of the public about the growing sense of lawlessness surrounding college football, including abuse of institutional academic requirements within the whole of intercollegiate athletics (Falla, 1981). Many colleges and universities, fearing overemphasis and 
seeing the dangers of the game, suspended football, including Columbia and Northwestern. Harvard President Charles Eliot threatened to totally abolish the game on his campus (Zimbalist, 1999).

According to Falla (1981), there was a sense that something needed to be done at the highest levels to regulate intercollegiate athletics as society clamored for the college game to adopt stricter rules. The response to this public outcry led to the initial meeting in 1906 that was the forerunner of the NCAA and created the Intercollegiate Athletic Association of the United States (IAAUS) (Falla, 1981; Watt \& Moore, 2001; Zimbalist, 1999). Although most of the concerns with college athletics focused on excessive violence, questions regarding the relationship of academics and athletics received almost as much attention at this first meeting and this attention manifested itself then and throughout subsequent years (Funk, 1991; Sack \& Staurowsky, 1998). Four years later in 1910, this association of colleges and universities officially became known as the National Collegiate Athletic Association. In the words of one of the founding fathers, and later the first President of the NCAA, Captain Palmer Pierce of The United States Military Academy at West Point, the association would be forever known as "the voice of college sports" (Falla, 1981; Sack \& Staurowsky, 1998; Zimbalist, 1999).

History of Student Athlete Academic Eligibility Standards

When athletic reform efforts regarding academic eligibility for intercollegiate athletics were created, colleges and universities were trying to protect the integrity of their academic mission and the intellectual environment while trying to allow the student athlete the benefits that both provide (Watt \& Moore, 2001; Zimbalist, 1999). Later in the $20^{\text {th }}$ century, intercollegiate athletics had become more commercialized, bringing in ever increasing revenue and stature to schools with winning teams. Intercollegiate athletics have served a variety of needs for the 
institution and various constituencies. College administrators have often felt the exploits of their athletic teams attracted monies from the state, alumni, and through other factors like ticket sales and fund raising opportunities (Chu, 1975; Underwood, 1984).

Studies done over the years conclude that athletes are unprepared for and uninterested in academics and come to college primarily to advance their athletic careers rather than their future vocational careers; therefore, they have lower grade point averages, higher attrition rates, and lower chances of graduating that other students (Adler \& Adler, 1985; Cross, 1973; Edwards, 1984; Harrison, 1976; Nyquist, 1979; Purdy, Eitzen, \& Hufnagel, 1982; Sack \& Thiel, 1979; Spivey \& Jones, 1975; Webb, 1968). For many years, colleges and universities turned away from academic requirements to allow under-prepared students who are blessed with athletic ability on campus just to participate in athletics while academics became a forgotten entity (Dodd, 1999).

Colleges and universities have recruited, trained, and exploited a seemingly endless procession of students for their athletic ability, casting them off when their eligibility ends. Many institutions often look the other way when a student athlete begins to fail academically (Wyatt, 1999). Viewing the benefits of intercollegiate athletics in a more practical sense, athletics has given a large number of student athletes the opportunity to attend colleges and universities who otherwise might have not attended (Blackburn \& Nyikos, 1974). Intercollegiate athletics has become a dichotomy. It can be good or bad for the participants, dependant primarily on the goals and motivation of the institution. If athletics have become dehumanizing and show less respect for fun and fair play, the research suggests that the reason lies in the fact that sports today are organized around the needs of frustrated adults (Zimbalist, 1999), the commercialization of the games, the emphasis on revenue, and winning, rather than around the values of the sandlot and high school and college participants (Alley 1974; Tunis, 1958). 
The over emphasis of athletics has led to an inevitable clash of academic integrity versus athletic success at intercollegiate institutions. In simple terms, a student athlete must remain academically eligible in order to compete. If one is not academically eligible and making satisfactory progress towards a degree, competition for that individual is prohibited (NCAA, 1983, 1986, 1991, 1996, 1999, 2000). Many people, whether students, boosters, academicians, alumni, or coaches have tried, and in many cases, have succeeded in beating the system (Falla, 1981). The effort and business of superceding academic requirements to gain athletic success is almost as old as intercollegiate athletics itself. The abuse of academic requirements began to spread to the primary and secondary levels of education where outstanding athletic prospects existed. College and university personnel began to influence the education, or lack thereof, of prospective student athletes by bending the rules primarily by falsifying transcripts and standardized admission test scores, to gain the admission of the prospect to the institution. Academic abuse at the base of higher education denied some individuals the chance to be successful in college, or admitted many who just were simply not prepared or skilled enough to go to college. If a prospective student athlete was not prepared academically for the rigors of college level work, graduation could be an unattainable goal. A high proportion of incoming freshman student athletes up until the mid 1980s fit this category. (Chu, Seagrave, \& Becker, 1985). Hanford (1974) reaffirmed this predicament when he stated that, "the problems of intercollegiate athletics will be solved only when its relationship to the education process is finally defined" (p. 336).

In 1986, the NCAA enacted NCAA Bylaw 5-1 (j), later to be known as NCAA Bylaw 14.3 (see Appendixes A \& B), or what is more commonly called Proposition 48 (NCAA 1986, 2000). Proposition 48 enacted a national initial eligibility standard with requirements for 
prospective student athletes to be completed prior to initial college enrollment (Howard-Hamilton $\&$ Watt, 2001; NCAA, 1986). The requirements consisted of passing a specific number of college preparatory classes, achieving a certain grade point average in those college preparatory classes, and obtaining a corresponding ACT or SAT correlated on a sliding scale to a specific GPA. These standards were enacted to curtail potential academic abuses and increase the chances for a student athlete to be able to perform college level work and increase chances for graduation (Benson, 1991, 1994, 1997).

Predictors of Student Athlete Graduation Rates from the Literature Student Athlete's Perception of College Coach's Emphasis on Academics

The greatest impact on the academic success of any student athlete is usually provided by the coaching staff, particularly the head coach of the student athlete's team. A coach and/or coaches involved in the academic well-being of their student athletes and emphasizing the importance of academics can greatly increase the chance of a student athlete succeeding academically and graduating (Adler \& Adler, 1985). This philosophy applies to both revenue and non-revenue sports. Revenue sports are defined as a team sport that can generate revenue to help support itself. Non-revenue sports are those that typically generate little or no revenue and need subsidies to meet their operating budget. The two most common revenue sports are men's basketball and football, which in turn carry immense pressure for coaches to win. The less pressure to win, the more focus a coach can put on the academic well-being of a student athlete. Non-revenue sports coaches typically focus more on academics and are much more involved in the student's life outside of athletics (Adler \& Adler, 1985). In revenue sports, coaches are primarily hired and fired based on won-loss records, not for achieving high graduation rates. The pressure to succeed can detach a revenue coach from being involved in the academic success of 
his student athletes (Sperber, 1990). A revenue sport coach is likely to be excessive in his demands on the time of their athletes for athletic purposes and not for academic purposes (Purdy, Eitzen, \& Hufnagel, 1982).

The level of the coach's involvement and whether that coach wants his or her students to graduate, or just stay eligible to compete is an indicator as to whether a student athlete will graduate from college. According to Adler and Adler (1985), incoming student athletes in revenue sports normally feel idealistic about academics when entering college, as coaches tout academics during recruiting. However, this often changes when the pressures of athletics begin to be felt. Many student athletes are shuttled by their coaches into "professor friendly" classes and easy majors so academics will not interfere with their athletic responsibilities. If coaches are threatened with their employment, athletic success of the team will almost always take priority over the academic success of the student athletes (Sperber, 1990). A student athlete's academic performance is significantly affected by coaches' intervention in their academic lives (P. Adler \& P.A. Adler, 1985).

\section{The Use of Specialized Academic Support Services for Student Athletes}

Virtually all institutions in NCAA Division I athletics, provide an array of advisors, tutors, and mentors to help athletes learn how to balance the demands of the classroom and the playing field (Suggs, 1999). Many researchers (Ervin, Saunders, Gillis, \& Hogrebe, 1985; Kennedy \& Dimick, 1987; Petrie \& Russell, 1995; Watt \& Moore, 2001; Young \& Sowa, 1992) have suggested that student athletes face a unique set of challenges that they are not ready to meet without assistance. Student athletes are a diverse special population because of their roles on campus, their atypical lifestyles, and their special needs (Ferrante, Etzel, \& Lantz, 1996). 
Effective models of student athlete support programs share several essential components (Carodine, Almond, \& Gratto, 2001).

Figler and Figler (1984) indicated that academic advisors and counselors for athletes provide eligibility monitoring, course selection, assessment of skills deficiencies, tutorial assistance, and study hall, in addition to personal and career counseling. In general, academic advisement and extended orientation are important. The goal is to assist all student athletes in the department with their academic, athletic, and social development (Reyes, 1997; Stier, 1992). Specifically, the ideal program should include academic support, career counseling, and personal development for student athletes. Services provided for student athletes by institutions have assisted the student athlete in balancing these three areas of their college experience (Carodine, Almond, \& Grotto, 2001; Reyes, 1997). Some studies argue that although most student athletes had poor academic records in high school, they have higher GPAs, lower attrition rates, and a greater likelihood of graduating than non-athletes because they receive extra tutoring and more specialized academic attention (Hanks \& Eckland, 1976; Henschen \& Fry, 1984; Michener, 1976; Shapiro, 1984).

Specific Sport Played in College

Revenue sports, primarily football and men's basketball at most NCAA Division I institutions, bring large sums of money to Division I schools. The term revenue sport is used in contrast with the term non-revenue sports, which refer to sports such as volleyball, tennis, swimming, and softball (Howard-Hamilton \& Watt, 2001; Kirk \& Kirk, 1993). Revenue sports typically generate money and exposure for colleges and universities. This revenue and exposure can lead to an over-emphasis on revenue sports to winning games rather than academic achievement (Eitzen, 1986). The two sports most focused in on as revenue sports in Division I 
intercollegiate athletics are men's basketball and football. For some years, news reports have revealed low graduation rates for college athletes who participate in revenue generating sports such as football and men's basketball (Snyder, 1996). According to Purdy, Eitzen, and Hufnagel (1982), student athletes who are involved in individual and non-revenue sports were similar to the general student population and secured better college grades and were more likely to graduate than those who participated in team sports. In addition, their study noted that admission of academically marginal student athletes is primarily in the sports of football and men's basketball.

The average athlete on a top college football or men's basketball team enters college at the bottom quarter of his class (Naughton, 1997). Males in non-revenue sports show relatively high levels of academic performance, especially on the SAT and ACT. Males in revenue sports show the lowest academic performance of all groups studied and had the largest number and percentage of recruits declared ineligible by the NCAA Clearinghouse (Benson, 1997).

Between 1994-1999, the graduation rates of student athletes in football and men's and women's basketball fell to their lowest level in seven years (Suggs, 1999). This can be attributed to the status of those sports and the emphasis on winning games, rather than academic achievement. The pressure on institutions to win in these sports and generate revenue can be immense. Pressures like this persuade institutions to focus on getting athletes and not students to increase the chances of winning (Sperber, 1990; Suggs, 1999). Another possible correlation is that student athletes in these sports have the opportunity to professionalize and make millions of dollars in salary. Other revenue sports and all non-revenue sports typically have higher graduation rates than football and men's basketball (Benson, 1994, 1997; Either, 1997, Eitzen, 1986). Athletes in these sports are not preoccupied with the possibility they may one day play professionally and they realize that their education is more important and they are not distracted 
by the thought they may one day be millionaires (Eithier, 1997). There is evidence that athletes in the revenue sports of football and men's basketball have a relatively low probability of receiving an education compared to non-athletes of athletes in the other sports due to the intense pressure to win (Adler \& Adler, 1985; Odenkirk, 1981; Underwood, 1980).

\section{Ethnicity}

The ethnic background of a student athlete can have a significant impact on the predictability of graduation from college. African American student athletes are especially affected as noted by their relatively low graduation rate in comparison to athletes of other backgrounds since the establishment of the Student Athlete Right to Know Act (Benson, 1994). African Americans, in general, enter college less prepared than Caucasian student athletes and graduate at a significantly lower rate than other ethnic groups (Benson, 1994). Eitzen and Purdy (1986) found significant differences between the predictors of college performance and graduation (SAT/ACT result, high school rank, and high school cumulative grade point average) in favor of white athletes over African American athletes.

NCAA efforts to increase initial eligibility standards have had dramatic impact on ethnic backgrounds, other than Caucasian, specifically amongst African Americans. In general, the effect is on low socio-economic classes in which the majority is of a non-white background. Many coaches and athletic administrators charge that the higher standards make it more difficult for students from disadvantaged backgrounds to earn athletic scholarships (Either, 1997). While graduation rates for African Americans and other minority groups has risen since 1991, the numbers from those groups enrolling in college in college has dropped, primarily due to increased NCAA initial eligibility standards (Witham, 1995). 


\section{Gender}

Female student athletes traditionally graduate at a much higher rate than their male counterparts (Benson, 1991). They also differ from male athletes in that they have better preparation for college and have a better record of college achievement (Purdy, Eitzen, \& Hufnagel, 1982). In general, all college student athletes aspire to earn degrees while only onequarter aspire to professional sports careers (American Institutes for Research, 1989). Overall, female student athletes focus more on graduating from college, do not aspire to professional sports careers, and see college athletics as more of an extra curricular activity than their male counterparts. Young women realize their education is going to be important to them in their future (Either, 1997). Since formal records of Division I student athlete graduation rates began in 1991, the female student athlete has graduated at an average rate of nine percentage points higher than female mainstream college students (Either, 1997).

\section{High School Core-Course Grade Point Average}

High school core course grade point average is defined as a cumulative high school grade point average in 13 college preparatory courses as opposed to all courses taken. It is based on the calculation of the highest possible GPA in a selection of core courses taken (Benson, 1997; NCAA, 2001). The core courses evaluated are four units of English, two units each of Math, Science, and Social Science, two additional units of courses in any of the areas mentioned or foreign language, computer science, philosophy, or non-doctrinal religion, and one additional unit of English, Math, Science, or Social Science (Britz, 2000; NCAA, 2001). The specific courses are selected by the individual high schools and approved by the NCAA Initial Eligibility Clearinghouse (Benson, 1997; Britz, 2000; NCAA, 2001). The NCAA Clearinghouse was created as a national center to adjudicate all prospective student athlete records to meet the demands of a 
fair and accurate determination of initial eligibility for first year college student athletes (Benson, 1997; Britz, 2000).

The most consistently high predictor of student accomplishment in college is high school grades. This finding is consistent with a large number of previous investigations on the prediction of academic performance (Richards, Holland, \& Lutz, 1966). In 1983, a report by the American Council on Education stated that athletes were being admitted to college based on athletic ability and not academic ability. The report recommended that all incoming freshman student athletes have at least a 2.0 grade point average in college preparatory classes in math, English, science, and social science. The Report of the McIntosh Commission (1994), Richards, Holland, and Lutz (1966), and Summers (1991) stated that a 2.0 grade point average along with a corresponding college entrance exam score (SAT/ACT) score generally indicate the ability to do college level work and provides the best single prediction of college graduation. While the entrance exams have been criticized as culturally biased, a 1995 study by the United States Department of Education indicates that high school coursework and grades in those courses is the greatest barrier between athletes and college graduation (Witham, 1995)

ACT/SAT Test Score

The American College Testing Program Test (ACT) and the Scholastic Aptitude Test (SAT), administered nationally, have been used as valid predictors of graduation of students from college for several years. Nationally standardized tests initially were designed to measure academic preparation for college, but these tests are routinely used as critical screening devices for access to higher education (Benson, 1993; Crouse \& Trusheim, 1989; Hardogon, 1984). The ACT battery yields subtest scores from English, mathematics, social studies, and natural science. The SAT battery yields subtest scores from verbal and mathematics (Richards \& Lutz, 1967). 
About 1600 hundred colleges and universities require the SAT or ACT test for admission and in the application for scholarships (Beaver, 1996). Although both tests are commonly used as predictors for graduation from college, they were originally designed as predictors of performance only during the first year of college (Suggs, 1999).

Post-secondary institutions across the United States maintain that a student with a higher score on standardized tests will attain higher grades in college than a student whose score is lower. Although college admissions officers say other factors are important in deciding whether to admit a student, ACT and SAT remain the most important piece for college admittance (Beaver, 1996). A 1996 study by the National Center for Education Statistics found that $60 \%$ of the students scoring over 900 on the SAT graduated within five years while less that $50 \%$ scoring under 900 graduated (Suggs, 1999). Males in the sports of football and basketball score significantly lower on the SAT and ACT than do males in other sports and females in all sports (Benson, 1997). The use of the ACT and SAT score cutoffs in determining initial athletic eligibility and as a predictor for graduation has disproportionately affected minority and lower socio-economic classes who traditionally score lower on the tests and do not meet the minimum requirements to be accepted into college (Suggs, 1999).

Theoretical Basis

This literature on predictors of graduation for student athletes draws on Vroom's expectancy theory on human motivation (Vroom, 1964). The theory is applied to examine the relationship and motivation of predetermined predictors for graduation of student athletes and the effect those predictors have on the persistence and potential for graduation of Division I student athletes in a mid-major NCAA intercollegiate athletic conference. This theory can identify the factors or predictors that influence or motivate a student athlete to graduate from college. 
The expectancy theory is broken down into two parts of a cognitive model, which happens in three stages. The two parts are the concept of valence and the concept of force. The three-stage process of the theory of accomplishing or working toward accomplishing a goal consists of Expectancy (E), Instrumentality (I), and Valence (V). The concept of expectancy refers to the strength of a person's belief about whether or not a particular performance is attainable. In layman's terms, a person will be motivated to try a task, if he or she believes it can be done. The concept of instrumentality is a probability belief linking one outcome to another outcome. This can be applied as a high level of academic performance to graduation, better job prospects, and money, in a sense, a reward. In the concept of valance, it is assumed that a person has preference among outcomes or states of nature. Preference is defined as a relationship between the strength of a person's desire for or attraction toward two outcomes. In other words, an outcome is positively valent when a person prefers attaining a goal to not attaining that goal. A zero valence is when the person is indifferent to attaining the goal, while it is negatively valent when he prefers not attaining the goal.

In general, student athletes overall come to college less prepared that other non-athletic students (American Institutes for Research, 1989; Sellers \& Chavous, 1997; Sellers, Kuperminc, \& Waddell, 1991). An argument of lack of motivation would suggest that these differences in academic preparation are, in part, a function in differences in motivation (Sellers \& Chavous, 1997). There is evidence in the research indicating that athletic participation is linked with satisfaction with the overall college experience and may also increase motivation to complete one's degree, persistence in college, and actual degree completion (Pascarella, et al, 1996). The NCAA's almost exclusive focus on increasing initial eligibility standards has been based on the assumption that the academic problems of student athletes are motivational in nature. In a 1990 
survey in the Journal of Higher Education, most college head coaches believe that a lack of motivation and interest in school is the primary reason for student athletes not graduating (Cullen, Latessa, \& Byrne, 1990). The focus of recent NCAA reform movements has been toward making incoming student athletes as similar academically to the rest of the student body as possible by increasing the pre-college academic requirements for the initial eligibility of prospective student athletes (Sellers \& Chavous, 1997).

The Expectancy Theory supports the predictors in the literature in that it measures how motivation or lack thereof, may affect the expectancy of a student athlete to graduate. A college coach's emphasis on academics can significantly affect the motivation or expectancy of a student athlete to graduate if the emphasis and importance of graduation is not discussed or in turn, if it is held in high importance. A coach is the most prominent role model for the student athlete in college (Adler \& Adler, 1985). If that role model does not stress academic progress and graduation, the motivation and expectancy of the student athlete to graduate may be reduced. Using specialized academic support services may increase the expectancy to graduate if the programs available are viewed as helpful or as a necessity to graduate to the student athlete. The characteristics of the specific sport played in college may also increase or decrease motivation and expectancy to graduate from college. The literature indicates that revenue sports are primarily focused on winning, while non-revenue sports place more emphasis on academics and graduation than revenue sports. The academic atmosphere created by the sport played can influence the desire and ability of the student athlete to graduate within time frames established by the NCAA.

Previous studies have also used Vroom's Expectancy Theory in explaining student motivation, motivational factors on work performance, and also predicting academic 
performance. Geiger and Cooper (1964) used Vroom's Expectancy Theory to assess student motivation and found that three issues, increased GPA, superior post-college job performance, and increased self-esteem, best influenced increased motivation of student academic performance. To that end, what motivates people in general and how that motivation can be channeled to certain events, like attaining graduation must be discussed. Expectancy theory assumes that behavior results from conscious choices among alternatives whose purpose it is to maximize pleasure and minimize pain (Ratzburg, 1997).

The Expectancy Theory offers a promising model for studying the acceptance of educational change and forms the theoretical framework for many studies (Johnson, 1996; Vroom, 1964). Vroom (1964) defined motivation as a process governing choices made by persons or lower organisms among alternative forms of voluntary activity. The Expectancy Theory provides the theoretical basis for a study on predictors for the expectation of graduation from college for Division I student athletes, in that it measures motivation, expectation, and outcome, primarily a goal and the process by which someone will choose a path to accomplish or to not accomplish that goal. Vroom's expectancy theory directly relates to the aforementioned predictors in this study in that it measures motivation and desire to achieve a goal in all of the predictors.

Vroom developed the expectancy theory to measure what makes a person want to achieve something when it may not very easy to accomplish the task or may be even very unpleasant (Vroom, 1964). The strength or tendency to act in a certain way (motivation) depends on the strength of an expectation that an act will be followed by a given outcome and on the attractiveness of that outcome or greatest of the reward to an individual. For example, it may be an arduous experience to complete the requirements for a doctoral degree, but the rewards and 
outcomes after successful completion may far outweigh any difficulty in accomplishing the goal (Vroom, 1964).

\section{Statement of Problem}

An evaluation of NCAA Division I student athlete academic success must address predictors of graduation for student athletes. Sub-standard graduation rates for student athletes that are below that of an institution's general student body can demonstrate the lack of academic commitment toward student athletes on part of a specific institution or the lack of academic preparation on part of the individual student athlete (McMillen, 1991). Most college athletes ultimately become disillusioned with and detached from academics. Some student athletes begin their college careers idealistically, caring about academics and intending to graduate, but graduation may not end up being the end result due to the inherent pressures of intercollegiate athletics (P. Adler \& P.A. Adler, 1985).

The purpose of this study is to ascertain if the predetermined characteristics of ethnicity, gender, high school core course grade point average, ACT and/or SAT score, the sport played in college, student athletes perception of coaches' emphasis on academics, and the use of specialized academic support services to determine if student athletes from the Mid-American Conference conform to the profile of the expected graduate as represented in the literature, allowing us to generalize from previous research.

This study analyzes college senior athletes of what is defined as a NCAA Division I midmajor athletic conference testing assumptions in the literature to determine if these students are consistent with the literature's assessment of the predictor's potentially influencing graduation for student athletes in the Mid-American Conference. To qualify as an NCAA Division I institution, an NCAA member must sponsor at least seven sports teams for males and seven for females, or 
six teams for males and eight for females. There are other criteria that must be met including home football attendance, number of scholarships given, and departmental budget amounts (Howard-Hamilton \& Watt, 2001; NCAA, 2001). A mid-major athletic conference is a Division I conference that is not involved as a member of the Bowl Championship Series (BCS) in NCAA Division I Football (Suggs, 2001).

The specific intercollegiate athletic conference analyzed for this study is the MidAmerican Conference. The Mid-American Conference, headquartered in Cleveland, Ohio, was established in 1946 as a five-team league. It is the sixth oldest and fourth largest intercollegiate athletic conference in the NCAA. There are currently 13 member institutions split into an eastern and western division with a total student enrollment of more than 275,000 , including more that 5200 student athletes competing in 23 sports (Hazel, 2000). The 13 schools currently in the conference, along with their 2001-02 academic year enrollment numbers are:

The University of Akron, Akron, Ohio, Enrollment-23,000

Ball State University, Muncie, Indiana, Enrollment-19,000

Bowling Green State University, Bowling Green, Ohio, Enrollment-19,333

The University of Buffalo, Buffalo, New York, Enrollment-23,389

Central Michigan University, Mount Pleasant, Michigan, Enrollment-16,000

Eastern Michigan University, Ypsilanti, Michigan, Enrollment-23,000

Kent State University, Kent, Ohio, Enrollment-22,000

Marshall University, Huntington, West Virginia, Enrollment-16,000

Miami University (Ohio), Oxford, Ohio, Enrollment-16,000

Northern Illinois University, De Kalb, Illinois, Enrollment-23,000

Ohio University, Athens, Ohio, Enrollment-28,715 
The University of Toledo, Toledo, Ohio, Enrollment-20,876

Western Michigan University, Kalamazoo, Michigan, Enrollment-28,657

*Note: The University of Central Florida is a football only member or the MAC

beginning in 2003. This institution is not part of study since they will not sponsor all sports in the conference.

These universities are similar in size and overall mission. Many of these institutions are listed on the same Southern Regional Educational Board (SREB) peer institution survey. Some institutions may not be peers by SREB standards, but the Mid-American Conference institutions are peers athletically due to competitive equity, number of sports sponsored, and athletic budgets, academic profile of prospective student athletes, among many other areas. These particular institutions, like others in mid-major conferences, are more likely than BCS conferences to admit academic at risk student athletes. The Mid-American Conference is one of the few Division I-A conferences that allow admission of student athletes not academically eligible for competition during the initial year of enrollment (non-qualifiers), and admission exceptions for those student athletes who do not meet established institutional academic standards and are considered at risk academically (C. Peacock, personal communication, May 30, 2001; Messer \& Cherry, 2000). Academic at risk student athletes are defined as those who do not meet the requirements for initial athletic eligibility as freshman. The NCAA Initial Eligibility Clearinghouse reviews and issues initial eligibility decisions based on NCAA standards (Appendixes A and B). The two categories of academic risk athlete are non-qualifier and partial qualifier. Non-qualifier means a prospective student athlete may not practice, compete or receive an athletic scholarship during his freshman year due to not meeting the required academic standards. Partial qualifier means they meet the 
requirements for practice and athletic aid, but still cannot compete during the freshman year (NCAA, 2001).

Non-BCS conferences, like the Mid-American Conference, are more likely to admit academic at risk student athletes because the top-tier conferences have first choice of the prospective student athletes who do meet the standards (Messer \& Cherry, 2000). The remaining student athletes may be many who were not admitted to the BCS schools due to academic deficiencies. Typically, the mid-major conferences will take the chance of admitting academic at risk student athletes on the basis of athletic accomplishments and potential so that they may be better equipped to compete, especially in the revenue sports (C. Peacock, personal communication, May 30, 2001; Messer \& Cherry, 2000). Due to this phenomenon, student athletes in a mid-major conference, like the Mid-American Conference, present a diverse population along the academic spectrum to adequately assess the characteristics for graduation of Division I student athletes.

\section{Research Question}

The study is designed to answer the following research question and characteristics of graduation described in the literature:

Does the profile of the MAC athlete created from the information gleaned from the survey confirm the characteristics presented in the literature, thus allowing generalization of research based conclusions to Mid-American Conference athletes?

The following characteristics inspired by the literature are analyzed to describe the Mid-American Conference athletes and to compare the survey sample to the groups represented in the literature:

1. Student athlete's perception of college coaches' emphasis on academics.

2. The extent of use of specialized academic support services for student athletes. 
3. Specific sport played in college

4. Ethnicity

5. Gender

6. High School Core-Course Grade Point Average

7. Score attained on SAT or ACT test.

Operational Definitions

American College Testing Program (ACT) Score - A response given by student athlete on the survey instrument.

Gender - A response of male or female reported on the survey instrument.

Graduation - An expectation of graduation reported on the survey instrument.

High School Core-Course Grade Point Average - Reported core-course grade point average, as defined by the NCAA, by senior student athlete on the survey instrument.

Ethnicity - A response of a specific ethnic group given by the student athlete on the survey instrument.

Scholastic Aptitude Test (SAT) Score - A response given by student athlete on the survey instrument.

Sport Played in College - Participation in specific sport or sports reported on the survey instrument.

Student Athletes Perception of College Coach's Emphasis on Academics -A set of responses given by student athlete on the survey instrument.

Use of Specialized Academic Support Services -A set of responses given by student athlete on the survey instrument. 


\section{Significance of Study}

The purpose of this study is to determine if the characteristics, as described in the literature, of race, gender, high school core-course grade point average, ACT and/or SAT score, what sport played in college, student athletes perception of coaches on academics, and the use of specialized academic support services for student athletes are confirmed, allowing for generalization of research based conclusions to the Mid-American Conference. A sub-standard graduation rate of student athletes is the most controversial issues facing intercollegiate athletics not only in the present time, but also literally since its inception (McMillen, 1991).

Understanding how the combination of academics and athletics influence the probability of graduation of student athletes at higher education institutions is important for any intercollegiate athletic administrator to understand. An intercollegiate athletics program requires higher education institutions to implement the administrative functions of planning, organizing, staffing, directing, coordinating, reporting and budgeting (Gulick \& Urwick, 1937). Understanding what characteristics can enhance the potential of graduation for Division I student athletes and to what extent assistance should be provided to the student athlete before, during, and after their athletic careers is crucial to the further development of programs, policies, and administrative functions governing intercollegiate athletics in higher education.

This type of information can be useful for several administrative functions and positions in higher education. For example, these data are useful for a college president who wants his athletic department to be viewed as one that values academics and graduation. It can assist in planning a mission statement for the Director of Athletics and a recruiting philosophy of only soliciting prospective student athletes who have the perceived ability, via these predictors, to be academically successful in college and increase their likelihood to graduate. The president and 
athletic director can also assess budgeting, staffing, and resource allocation needs within the university to assist in the graduation of student athletes, consequently generating more positive graduation rate reports. Athletic academic advisors can use this information to coordinate intervention strategies to assist at risk student athletes in performing better in college level academics and attaining graduation if they score low on a specific predictor or fit into a high risk category.

If the mission statement of the importance of graduation of student athletes being important is communicated to the coaches and if coaches' evaluations are based in part on actual graduation rates of student athletes, a coach will be more apt to use this knowledge combined with athletic talent in recruiting and selecting student athletes. These characteristics are also very useful to the student athlete and their parents or guardians in knowing what specific academic issues on which to focus early in their scholastic years to insure that they are better prepared for college academics and the possibility of graduating from college in addition to playing college sports.

Several types of information must be understood about prospective student athletes. These include primary and secondary education requirements, the treatment of elite athletes by society prior to admission into college, and motivations to attend college, whether academic, athletic, or both. An intercollegiate athletic administrator must also have an understanding of the workings and standards of the specific institution for which he or she is working. These standards include admission and NCAA initial eligibility standards, satisfactory progress and percentage of degree requirements for student athletes as opposed to the general student body, academic support and life skill development programs available for student athletes while enrolled in college, and student athlete graduation rates. Understanding these specific areas and effectively addressing the 
characteristics that produce a significantly greater chance of graduation can lead to the successful creation and implementation of successful programs in intercollegiate athletic departments that insure academic and athletic success of the student athlete without sacrificing the academic integrity of the institution. These types of programs can enhance recruiting of academically capable student athletes, planning and goal setting for the university as well as the athletic department, and ultimately improve the academic standing of student athletes in higher education and give them a better opportunity and reason to achieve a baccalaureate degree. The dichotomy between athletics and academics co-existing in higher education has been an emotional struggle for those who advocate intercollegiate athletics in higher education and those who do not. Even after a century worth of academic versus athletic arguments, never has one issue so challenged segments of the intercollegiate athletic community as much as the graduation rates of student athletes (Byers, 1995; Funk, 1991; Knight \& Knight, 1991, 1993; Lapchick, 1989; McMillen, 1991; Thelin \& Wiseman, 1989).

The information gathered for this study will add to the current body of knowledge available on NCAA Division I student athletes and graduation. Specifically, the study addresses if the characteristics can be generalized to the Mid-American Conference. The results of this study can be used as a useful evaluation tool by administrators in the Mid-American Conference, to determine if these characteristics improve the chance of graduating for its' student athletes.

\section{Limitations and Assumptions}

The purpose of this study is to determine if the constructs of race, gender, high school core-course grade point average, score achieved on the ACT and/or SAT test, sport played in college, student athletes perception of college coaches emphasis on academics, and the use of specialized academic support services confirm the characteristics and expectancy of graduation 
presented in the literature allowing for generalization of research based conclusions found to MidAmerican Conference athletes.

Graduation from college is measured by the NCAA as obtaining a baccalaureate degree within six years of date of initial enrollment. This is the standard used for NCAA Division I and II universities (Benson, 1994; NCAA, 2001). This study uses data obtained from subjects within five years of initial enrollment who have one year or less until graduation. This differs from NCAA studies in that the NCAA is able to obtain data directly from the institutions post graduation, which the researcher could not, without specific required release authorization. The researcher also could not guarantee complete anonymity if the data were obtained post graduation.

Several other limitations exist in this study. This study is designed as a descriptive study (Johnson \& Christensen, 2000; Neumann, 1991). Descriptive research presents specific details of a situation in social settings by describing the characteristics of the population by examining samples of that population (Glatthorn, 1998; Neumann, 1991). The population itself is a demographic selection of those student athletes who will most likely graduate within five years of initial enrollment, but at the time the survey instrument was administered, none of the student athletes surveyed had graduated. Logistic and time concerns prevalent throughout the research prevented an analysis of the population post-graduation. Several data items will be based on the recollection of each individual as in the case of grade point average and score attained on the SAT or ACT. Actual recorded data could be obtained; however, complete anonymity cannot be guaranteed should that occur. The researcher's assumption is that these items are of such importance to an incoming freshman student athlete that the data should be relatively close to accurate. 
The survey instrument itself is also a limitation. Although the instrument was reviewed by a jury of experts (Appendix 3) and pilot studied for readability and face validity, it is a new survey constructed by researching the literature and existing questionnaires on intercollegiate athletics using self report data. A single survey instrument used for the first time may lack the validity that an established survey instrument has in measuring the data (Johnson \& Christensen, 2000). In addition, the survey instrument was distributed to a contact in each institutions athletic department for distribution to the selected student athletes. Since the survey instrument was not mailed directly to the student athlete, there may exist some bias in the reported answers due to the method of delivery via a person in authority in a particular athletic department to an individual student athlete.

\section{Summary}

Success and satisfaction with the college experience depend in large part on readiness and motivation of high school graduates to take advantage of college-level learning and personal development opportunities (Benson, 1994). Graduation of student athletes is an area of primary concern for higher education administrators due to the popularity of intercollegiate athletics and the public scrutiny that is focused on academics and athletics (Knight \& Knight, 1991, 1993). Of even greater concern, many athletes are given academic advice designed to keep them eligible rather than to advance legitimate educational goals. In one-third of Division I men's basketball programs, fewer that one in five players ever graduate. The graduation rate in football is only slightly better (Knight \& Knight, 1991, 1993). The claim that athletes are students first and athletes second lacks credibility. In the end, it is the integrity of the university that is undermined (Knight \& Knight, 1991, 1993; “The Crisis,” 1990). 
The integrity of institutions that sponsor NCAA Division I athletics depends on whether or not the institution wants to control the intercollegiate athletic department's athletic activities. One primary way to exert institutional control over an intercollegiate athletic department is to directly address the academic and non-academic issues that enhance and influence graduation of student athletes. If an athletic department has a high graduation rate and shows a commitment to the academic well-being of their student athletes, the integrity of the institution is maintained. If the prediction or likelihood of graduating from college for a student athlete can be attributed to the listed academic and non-academic predictors, intercollegiate athletic departments nationwide should use this information to increase the probability of graduating their student athletes.

This study is a descriptive study that determines if several predetermined characteristics that influence graduation from college for a NCAA Division I student athlete confirm what is presented in the literature allowing for generalization of research based conclusion to the MidAmerican Conference. The Mid-American Conference, a mid-major NCAA Division I intercollegiate athletic conference, is more likely to admit academic at risk student athletes to their institutions. All NCAA institutions have an obligation to provide the best possible opportunity for their student athletes to graduate, not to bear the full responsibility. An institution that believes it is responsible to graduate the student athletes, may also feel a reason to circumvent rules and regulations of academic honesty (Sperber, 1990). The NCAA membership has come a long way in enhancing the graduation rates of student athletes, but there is room for improvement. In too many instances the winning of an athletic contest is considered more important than the education and graduation of student athletes ("The Crisis," 1990).

To protect the values of higher education, every effort must be made to continue to strengthen the role of academics for student athletes. Solidifying the role of academics and 
importance of it can continue to enhance the graduation rates of student athletes and communicate down to the primary and secondary education levels that to play interscholastic and intercollegiate sports, education comes first. Addressing this problem can increase graduation rates of all student athletes in all divisions and protect the integrity of higher education. 


\section{CHAPTER II}

\section{Review of the Literature}

\section{Introduction to Intercollegiate Athletics}

Today, thousands of college students compete in intercollegiate athletics on varsity and sub-varsity sports teams sponsored by the National Collegiate Athletic Association (NCAA) or other national governing bodies. Intercollegiate athletics have been a part of higher education and university life since the early $18^{\text {th }}$ century when athletics were made part of the curriculum at the Rugby School of England. Intercollegiate athletic competition in the United States, albeit primarily unsanctioned, is traced back as early as the 1820 s to crew competitions, football, and rugby games between Ivy League schools like Harvard, Yale, and Princeton (Falla, 1981; Howard-Hamilton \& Watt, 2001). Almost from the day that Rutgers and Princeton played the first official intercollegiate football game in 1869, educators and other people have decried the overemphasis of sport as contrary to the mission of higher education (Deford, 2001; Ryan, 1989; Stone \& Strange, 1989; Telander, 1996).

At the university level, intercollegiate athletics can have a positive effect on university life and increase the quality of the overall educational experience for the student athlete, university, and local community, as well as for graduates and alumni of the institution. Athletics is an important part of life for undergraduates. It interests and fascinates an enormous number of citizens who claim no alma mater, but who love the color, the pageantry, and the sheer competition of sporting events (“The Crisis," 1990). Athletic participation during the college years can improve the individuals' ability to get through the academic rigors of college and better prepare a student athlete for life outside of athletics in that it promotes growth in interpersonal skills, leadership abilities, and increases self-esteem (Richards \& Aries, 1999; 
Ryan, 1989; Taylor, 1995). Coaches believe that sports develop certain desirable social values. The commonly listed traits are kindness, cooperation, truthfulness, courage, loyalty, friendliness, and character (Edwards, 1973; Frost, 1973; Kneller, 1965). Intercollegiate athletics have given a large number of student athletes the opportunity to attend colleges and universities who otherwise might not have attended. A proportion of these athletes from impoverished backgrounds have graduated from college and benefited society (Blackburn \& Nyikos, 1974). Like other specialized educational pursuits, sports are environmentally cultivated and provide opportunities to satisfy the strong human drives for recognition and achievement (Gilbert, 1974; Ogilvie \& Tutko, 1971). Family members, peers, teammates, teachers, and coaches applaud a young athlete's accomplishments. Individual athletes with outstanding sports records are recognized and often honored for their achievements (Clarke, 1975; Underwood, 1984).

However, playing an intercollegiate sport can add an unexpectedly complex layer to student life. Student athletes face all the challenges that non-athletes face in relation to the daily student routine, but student athletes also have their sport-related activities. Student athletes constantly cope with balancing the roles of student and athlete (Ferrante, Etzel, \& Lantz, 1996; Martens \& Lee, 1998; Street, 1999, Watt \& Moore, 2001). Understanding the historical development of the popularity of college athletics can help one understand the breadth and depth of the conflict between the academic and athletic worlds of the student athlete (Watt \& Moore, 2001).

Values in intercollegiate athletics have changed dramatically over the years. In the late 1800s, after intercollegiate athletics took a stronger foothold on campuses across the country, college sports were played for fun and leisure. The faculties and administrators in early higher education never planned for anything as frivolous as athletics. The concentration was 
solely on academics. Still, students gravitated toward recreational activities that college authorities saw as a method for the students to release pent up energies (Chu, Seagrave, \& Becker, 1985). In the 1920s, the importance of physical education in higher education was emphasized by almost all institutions having a requirement in physical education. This combined with an increased emphasis on intercollegiate athletics, made physical education a big business on campuses of higher learning. The 1920s became known as the golden age of college sports. The students had new freedoms, new drives, and new searchings for emotional and physical outlets. College sports seemed to provide the one common denominator (Wilson, 1967). Later in the $20^{\text {th }}$ and now into the $21^{\text {st }}$ century, intercollegiate athletics have become more commercialized, bringing in ever increasing revenue and stature to schools with winning teams. Athletics have served a variety of needs for the institution and its various constituencies. College administrators have often felt the success of intercollegiate athletics in the form of winning records and in attracted monies from the state and alumni (Chu, 1979; Underwood, 1984).

The words "student" and "athlete" combined have sometimes been viewed as an oxymoron (Broadhead, 1992; Cullen, Latessa, \& Byrne, 1990; Naughton, 1996). Colleges and universities have recruited, trained, and exploited a seemingly endless procession of students for their athletic ability, casting them off when their eligibility ends. Administrators and coaches often look the other way when a student athlete begins to fail academically (Wyatt, 1999). Viewing the benefits of intercollegiate athletics in a more practical sense, athletics has given a large number of student athletes the opportunity to attend colleges and universities who otherwise might have not attended (Blackburn \& Nyikos, 1974). Intercollegiate athletics can be good or bad for the participants, dependant primarily on the goals and motivation of the institution (Alley, 1974). The literature suggests that the reason lies in the fact that sports are 
organized around the needs of frustrated adults, the commercialization of the games, and the emphasis on revenue and winning, rather than around the values and education of high school and college participants (Alley 1974; Tunis, 1958).

Over emphasis on athletics has led to an inevitable clash of academic integrity versus athletic success at institutions that sponsor intercollegiate athletics. In simple terms, a student athlete must remain academically eligible in order to compete. If one is not academically eligible and not making satisfactory progress towards a degree, competition for that individual is prohibited (NCAA, 2001). Thus many people such as students, boosters, academicians, alumni, and coaches, have tried, and in many cases, have succeeded in beating the system. The effort and business of superceding academic requirements to gain athletic success has been around since the beginning of intercollegiate athletics itself (Axthelm, 1980).

The abuse of academic requirements began to spread to the primary levels of education where outstanding athletic prospects existed. College and university personnel began to influence the education, or lack thereof, of prospective student athletes in high school by bending the rules primarily by falsifying transcripts and standardized admission test scores, to gain the prospect admission to the institution (Axthelm, 1980). Academic abuse for athletic success at the high school level never gave some individuals the chance to be successful in college, or many who were admitted to a university not prepared or skilled enough to go to college (Axthelm, 1980; Briggs, 1997; Underwood, 1984). If a prospective student athlete was not ready or prepared academically for the rigors of college level work, graduation became an almost unattainable goal. A high proportion of incoming freshman student athletes up until the mid 1980s fit this category (Chu, Seagrave, \& Becker, 1985). College athletes are believed to be less academically able and usually enter college with lower high school grades and test scores. Student athletes 
who are poorly prepared for college level work have been found to disengage themselves from academic roles (Adler \& Adler 1985; Engstrom \& Sedlacek, 1991; Hanford, 1974; Hood, Craig, \& Ferguson, 1992; Lorimer, 1972; Purdy, 1981; Stuart, 1985).

\section{History of Intercollegiate Athletics}

Thelin (1994) refers to college and university athletics as a "peculiar institution of higher education. Their presence is pervasive, yet their proper balance with academics remains puzzling” (p. 1). According to Sperber (1990), intercollegiate athletics participation and competition have been scarred by abuse of academic requirements for athletic eligibility almost since its very beginnings. American intercollegiate athletics and its players have been shrouded in doubt and skepticism since its inception. The concern of athletics success versus academic requirements is not a recent phenomenon of modern times. Abuse of academic requirements in intercollegiate athletics requirements has had a long and sordid history (Ryan, 1989; Sperber, 1990).

As early as the 1890 s prominent universities were determined to win in intercollegiate sports at any cost. While football was the main focus of colleges and universities, other sports were also starting to supercede academic requirements to get athletes on the field. Professional baseball pitchers were becoming campus stars playing college baseball under pseudonyms. Coaches were inserting themselves and non-students into football games. (Zimbalist, 1999) These abuses of institutional and academic standards that governed extra curricular activities on most college campuses led to the eventual development of the National Collegiate Athletic Association (NCAA) as the governing body of intercollegiate athletics (Byers, 1995; Falla, 1981; Zimbalist, 1999). 


\section{The Beginning of Academic and Eligibility Regulation in the NCAA}

In the 1920s intercollegiate athletic competition grew exponentially across the nation. Colleges and universities were adding sports and building formidable athletic programs in the process. The NCAA membership held its first championship in the sport of track and field in 1921 (Byers, 1995; Falla, 1981). The post World War II era brought forth the first significant rules and regulations adopted by the membership as a whole. The post-war NCAA returned to the business of restoring and maintaining integrity in intercollegiate athletics. The first NCAA "convention" was actually called the "Conference of Conferences" in July of 1946. The participants in this conference drafted a statement called "Principles for the Conduct of Intercollegiate Athletics.” (Brown, 1999; Sack \& Staurowsky, 1998). According to Falla (1981) and Brown (1999), the principles concerned adhering to the definition of amateurism and not allowing professional athletes to compete, holding student athletes to the same sound academic standards as the student body, awarding financial aid without consideration for athletics ability, and developing a policy of recruiting that basically prohibited a coach or anyone representing a member school from recruiting any prospective student athlete with the offer of financial aid or any equivalent inducement. These principles collectively became known as the Sanity Code, or Article III of the NCAA Constitution when it was first presented in 1947. This code was initially developed to help colleges and universities deal with the growing levels of abuse and violations in intercollegiate athletics, specifically football and men's basketball. The code was a tortured, yet in some ways a brilliant effort to reconcile a number of disparate interests and athletic philosophies concerning intercollegiate athletics (Falla, 1981; Sack \& Staurosky, 1998, Sperber, 1998; Zimbalist, 1999). 
During the development of the sanity code, values in intercollegiate athletics remained skewed toward winning and athletic success, rather than academic achievement and graduation (Byers, 1995). In the late 1800s, after intercollegiate athletics took a stronger foothold on campuses across the country, college sports were played for fun and leisure. The faculties and administrators in early higher education never planned for anything as frivolous as athletics. The concentration was solely on academics. Students clamored for some types of recreational activities that would be a respite from the daily rigors of academic life (Chu, Seagrave, and Becker, 1985). In the 1920s and 1930s, almost all institutions having a requirement in physical education emphasized the importance of physical education in higher education. An academic requirement of physical education combined with an increased emphasis on intercollegiate athletics, made physical education a big business on campuses of higher learning. The 1920s became known as the golden age of college sports. Students had new freedoms, new drives, and new desires for emotional and physical outlets. College sports seemed to provide the one common denominator (Wilson, 1967).

\section{History of Eligibility Standards}

\section{The First NCAA Constitution}

Intercollegiate athletics in the early 1900s was also facing other issues outside of the academic arena, similar to issues that colleges and universities still deal with today. The issues included amateurism, academic integrity, financial aid to student athletes, and recruiting restrictions, and violations. The birth of the NCAA brought the once shockingly high death rate of football players prior to 1910 to an almost non-existent low, while keeping once-rampant academic cheating and pay-for-play under control (Byers, 1995). Even though off and on the 
field rule problems were minimized, as the competition grew larger nationwide, the abuses of academic requirements became tougher to control by the NCAA membership (Byers, 1995).

Like the Constitution of the United States, the first NCAA Constitution, in addition to the Sanity Code itself, had many aspects that apply today in the areas of initial athletic eligibility and satisfactory academic progress. These aspects led to the reform of intercollegiate athletics and the restructuring of initial eligibility academic standards for incoming student athletes. In the case of Articles 2 and 8 of the initial Constitution, Article 2 states, "Its object shall be the regulation and supervision of college athletics throughout the United States, in order that the athletic activities may be maintained on an ethical plane in keeping with the dignity and high purpose of education" (Falla, 1981, p. 134-135). Article 8 continues on to address the area of intercollegiate athletic and academic ability stating that "The Colleges and Universities in the Association severally (sic) agree to take control of student athletic sports, as far as may be necessary to maintain in them a high standard of personal honor, eligibility, and fair play, and to remedy whatever abuses may exist" (Falla, 1981, p. 135).

Article 8 stated that not all institutions agreed to uniform levels of eligibility, and only agreed to maintain eligibility integrity at the level of the institution. Article 7 also states in part, "The acceptance of a definite statement of eligibility rules shall not be a requirement of membership in this Association. The constituted authorities of each institution shall decide on methods of preventing the violations of the principles laid down" (Falla, 1981, p. 135). Article 7 became a precursor to many of the eligibility and graduation rate issues that would plague intercollegiate athletics throughout the twentieth century. Leaving eligibility certification issues up to individual institutions, and not to a national standard, created a climate that was ripe for 
abuse. In the earliest parts of the century, this issue was not particularly important, considering the effort it took just to reform the sport of college football (Byers, 1995).

Some eligibility rules existed for all institutions, at least philosophically. What little space the new bylaws took in the first rules and regulation manuals of the NCAA, a significant portion was dedicated to a philosophy of academic integrity for athletic departments and a direction that something needed to be organized to maintain some sort of standard in academic eligibility for student athletes. The Sanity Code itself was limited to 12 points or rules. Only two of these points addressed academic eligibility and it pointed to institutional requirements as the benchmark for intercollegiate athletic eligibility (Falla, 1981). Article 5 simply states that institutions must insist upon normal academic progress toward a degree, while Article 6 specifically addresses initial eligibility by saying, "Deny eligibility to any athlete not admitted under the institution's published entrance requirements" (Falla, 1981, p. 135, Zimbalist, 1999). Institutional standards for initial eligibility were maintained, not a national standard, for the first 30 years of the NCAA and its regulating body predecessors. Yet, the clamoring for some type of national standard on entrance requirements and satisfactory progress toward a degree was being talked about as many intercollegiate athletic programs spiraled out of control into the abyss of academic abuse for athletic gain (Byers, 1995). The expansion of radio and later television coverage brought with it more interviews of inarticulate student athletes using less than grammar school syntax. Functional illiteracy among student athletes was starting to come to the public's attention (Zimbalist, 1999).

It was at the 1947 NCAA Convention that eligibility standards began to take on a more national standard for the first time. This led to the development of the academically oriented sanity code and later the first NCAA Constitution. Issues addressed were defining full-time 
enrollment, transfer regulations, and a nationwide ban on freshman competition. Initial eligibility was still defined as being admitted under the published admission rules and requirements of each individual institution. Several satisfactory progress issues were addressed in the ensuing year while initial eligibility was not, nor looked at as important, because freshman at the time were ineligible for competition (Falla, 1981; Byers, 1995). Even though freshman remained automatically ineligible for competition in their initial year until 1972, initial eligibility for practice and athletically related financial aid during the freshman year remained an important issue impacted by standards that existed (Byers, 1995).

The sanity code was the first attempt at establishing intercollegiate athletic eligibility standards for the NCAA membership as a whole (Byers, 1995; Falla, 1981). The first official draft of the sanity code was presented for discussion at the 1947 NCAA convention, while a modified version of Article III passed at the 1948 convention (Falla, 1981; Sack \& Staurowsky, 1998). Many institutions could not come into compliance with the sanity code, especially in the southern states, because of widespread payments to athletes by boosters. Some schools, led by the University of Virginia, revolted against the original Sanity Code to protect themselves from alleged eligibility violations at their own institutions, and threatened pulling out from the NCAA. If fully enforced, the sanity code would have resulted in Virginia's and other schools banishment from the NCAA (Falla, 1981; Sperber, 1998). In 1951, most of the original Sanity Code was officially repealed by the membership, but the core of eligibility legislation it represented remained as the NCAA membership grew. Eligibility status for athletes being certified by the member institution remained unchanged in principle for a period of over 20 years (Brown, 1999; Falla, 1981). The acknowledged need for regulation and enforcement of eligibility standards appeared to be the enduring legacy of the short-lived Sanity Code (Falla, 1981). 


\section{The Development of National Initial and Continuing Eligibility Standards}

In 1962 the NCAA Executive Committee, a committee made up of primarily educators and administrators at NCAA member institutions, allocated funds to finance a study to see if academic success can be predicted for student athletes based upon their high school academic record and initial year of collegiate enrollment. The purpose of this study was to see if it could be predicted that a student athlete has a reasonable chance of getting a degree when he or she starts college. The philosophy of this committee was that intercollegiate sports are an integral part of the total educational pattern and that student athletes representing the institution should be legitimate representatives of the student body in general (Falla, 1981; Knight \& Knight, 1991,1993). The committee recommended developing an expectancy table to determine predictors for academic success in college. The expectancy table that was developed produced a standard that is similar to the one used for freshman initial eligibility certification in the early eighties (Falla, 1981). The table was based on high school grade point averages and on scores achieved on one of the standardized entrance examinations, the American College Testing Program Test (ACT) or the Scholastic Aptitude Test (SAT). The 1965 NCAA Convention adopted what was called the expectancy table. The expectancy table was commonly called the "1.6 Rule." The 1.6 rule meant that incoming freshman, even though not eligible to compete, could not practice or even receive an athletic grant if they did not meet the 1.6 rule. The use of the standardized test was still left up to the institution. The 1.6 rule states, "A member institution shall not be able to enter a team or individual competitor in an NCAA sponsored meet unless the institution: 
1. "Limits its athletic grant-in-aid awards and eligibility for participation in athletics to incoming student athletes who have a predicted grade point average of at least 1.6 (based on a 4.0 scale) as determined by demonstrable, institutional, conference or national experience; and

2. Limits it subsequent awards and eligibility for participation to student athletes who have a grade point average, either accumulative, or for the previous academic year, of at least 1.6." (Falla, 1981).

Sports Illustrated Magazine and several college administrators called the 1.6 rule, "a long overdue piece of legislation designed to guarantee that every student athlete in all of the NCAAs member schools maintain at least a $\mathrm{C}$ minus grade point average. A mark of $\mathrm{C}$ minus amounts to 1.6 on a 4.0 grading system" (Falla, 1981, p. 146).

There were still several loopholes to this legislation, including what was still ultimately the individual institution's prerogative to determine who was eligible and who was not. Institutions were supposed to use the NCAAs tables, but were still able to use their own predictive tables, which were less demanding than the one passed at the convention. Several amendments were passed over the next few years demanding that institutions using tables less restrictive must have tables that are representative of the institution's student body and require a minimum level of academic attainment (Falla, 1981). There was much controversy during the years of the prediction tables and the impending thought of many that people from minority or disadvantaged backgrounds may find themselves off the field led to the next big impact legislation concerning initial eligibility. 
The first suggestion to use a 2.0 grade point average as a predictor of academic success in college for a student athlete was introduced at the 1973 NCAA Convention (Falla, 1981). This legislation superseded and replaced the prediction table system by stating, "athletic grants-in-aid be limited to athletes who have graduated from high school with a minimum grade point average of 2.0 for all work taken and certified officially on the high school transcript" (Falla, 1981). The rule also addressed satisfactory progress issues and the requirements needed to compete and maintain an athletic scholarship. The 2.0 rule addressed the issue of competition and athletic financial aid in a student athlete's first year, but did not tackle the issue of college preparatory classes and standard admissions, still leaving the admissions process of student athletes up to each institution. This standard would stay in place until the beginning of radical academic reform in intercollegiate athletics in 1984 (McMillen, 1991).

The NCAA first tracked graduation rates unofficially in the late 1970s after development of the 2.0 rule to better gauge if student athletes were indeed graduating and how their rate compares to the general student body (McMillen, 1991). The need for the 2.0 rule and the statistical information provided by the graduation rates met challenges by many in the NCAA membership. Several coaches, athletic administrators, and even faculty saw the need to let unprepared students into college by viewing the benefits of sports in a more win at all costs sense (Byers, 1995). Yet, numerous cases of academic dishonesty and fraud would dominate college athletics through the rest of the 1970s up to the reform-minded 1986 NCAA Convention (Sperber, 1990).

\section{Proposition 48}

According to Funk (1991), the publicity surrounding the academic shortcomings of intercollegiate athletics rose to the point of creating a public furor in the late 1970s and early 
1980s. The leaders of the NCAA and of America's colleges and universities, specifically college and university presidents, gathered to assess the problem and propose possible solutions (Funk, 1991; Lapchick, 1989, Sperber, 1990,). In 1982 the American Council of Education (ACE) put together an ad hoc group called the Committee on the Problems of Major Intercollegiate Athletics Programs. This group became the first noteworthy group to address the problem of institutional initial eligibility standards versus establishing a national initial intercollegiate athletic eligibility standard and served as a political force to get the proposition adopted ("The Crisis," 1990). The ad hoc committee was chaired by Harvard University President Derek Bok, and was comprised of 40 other college and university presidents. In September of 1982, committee members had written proposals that would toughen initial eligibility and academic progress rules for student athletes. It was decided that the committee would introduce two proposals to the 1983 NCAA January convention. They were as follows:

1. An initial eligibility standard for Division I intercollegiate athletics, commencing in 1986, would combine a minimum grade point average in a core curriculum of high school courses with minimum standardized test scores; and

2. To remain eligible for varsity competition after the freshman year, a student would, in addition to meeting all existing NCAA requirements, have to make satisfactory progress towards an academic degree and be in good academic standing as certified by appropriate academic authorities (Funk, 1991). 
The ad hoc committee later elaborated on these proposals by also seeking NCAA legislation requiring a prospective student athlete to graduate from high school with at least a 2.0 grade point average on a 4.0 scale in a core curriculum of 11 academic courses. The core curriculum was to consist of a minimum of three English courses, two mathematics courses, two social science courses, two courses in the natural or physical sciences, plus two others in foreign language, non-doctrinal religion, or other courses in the listed academic categories already mentioned. In addition, a combined score of 700 would be required on the SAT or a composite score of 15 on the ACT. These academic proposals would eventually become the foundation for future reform and would be realized in the form of the much discussed and controversial NCAA Proposition 48 legislation (Funk, 1991, Zimbalist 1999). The thought on this proposal was that if students are better prepared for college level work, they have a legitimate chance to graduate from college after competing for their respective teams. The surest way to improve the academic success of college athletes is to upgrade their academic performance when they are in high school (McMillen, 1991).

The first actual, enforced national standard for intercollegiate initial athletic eligibility was named Proposition 48, to mirror its legislative proposal title when first introduced at the 1983 NCAA convention (NCAA, 2001). It is now officially known in the current NCAA Manual as Bylaw 14.3. The ACE committee's proposal led the NCAA membership to vote this new sweeping initial eligibility legislation into effect. The proposal focused on core-course requirements, high school grade point averages, and standardized test scores of prospective student athletes and was passed in January of 1983, and gradually phased in 1986. The actual wording of the legislation is discussed in Appendix 1. 
The Proposition 48 standard, although passed in 1983, was not officially adopted for Division I colleges and universities until 1986. Funk (1991) explains that the national standard, while good in theory, still enabled individual high schools and colleges the choice and ability to choose what is a core-course at a specific high school. At this point in the process, administrators and coaches argued that nothing had been solved except new ways to manipulate the system to insure initial athletic ability for prospective student athletes (Funk, 1991). Funk (1991) also notes that aside from the lack of national control over the 1986 standards, many other issues such as perceived racially biased standardized tests, pushed the NCAA membership into later overhauling its Proposition 48 standard into a new more functional Proposition 42 in 1994. Proposition 42 and Proposal 16

Proposition 48 itself was very controversial legislation. Changes to enhance the Proposition 48 requirements were met with stiff resistance from several concerned groups (Benson, 1997; 1998, Byers, 1995; Sellers \& Chavous, 1997; Snyder, 1996). The Reports of the Knight Foundation Commission on Intercollegiate Athletics $(1991,1993)$ added some political, academic, and athletic input into the conduct of intercollegiate athletic programs. The public was sensing that due to Proposition 48, an actual, effective reform of intercollegiate athletics was beginning (McMillen, 1991). According to a Louis Harris poll conducted in $1989,78 \%$ of all Americans believed big-time intercollegiate athletics were out of control. A follow-up survey indicated only $47 \%$ held that view, a dramatic 31 -point decline from the previous poll (Knight \& Knight, 1991, 1993). The Knight commission's report consisted of dramatic recommendations about fund-raising, presidential control, as well as academic standards, specifically a recommendation to enhance the Proposition 48 standard. Members of the NCAA viewed the 
report seriously and it became a benchmark for future reform and the advent of presidential control of intercollegiate athletics in the 1990s (Knight \& Knight, 1991, 1993; McMillen, 1991).

On the subject of initial eligibility, the Knight Commission recommended raising the Proposition 48 standards that were in place, by August 1995, to insure all prospective student athletes have a reasonable chance of completing college. The newly proposed standards were for a prospect to present a 2.5 grade point average (out of a possible 4.0 ) in 13 core high school units, along with a combined minimum SAT score of 700, or a minimum 17 score on the ACT. Due to Proposition 48, the Knight Commission concluded that a solid start on the road to athletics reform had been made, but more needed to be done (Knight \& Knight, 1991, 1993).

In 1991, Proposition 42 was the beginning of experimenting with a "sliding scale" of a corresponding core-course GPA with test scores to assist prospective student athletes who achieve higher in either area while not performing as well in the other. It also marked the implementation of the provision eliminating athletically related financial aid during the initial year of enrollment for a non-qualifier, one who did not meet the established standard (Benson, 1993). The sliding scale standard would not officially go into effect until 1996 as Proposal 16 was passed as an amendment to Proposition 42 (NCAA, 1996). The sliding scale of Proposal 16 was roughly equivalent to the one used with the1.6 rule, high school GPA, and core-courses (Padilla \& Walker, 1994).

The development and initiation of this legislation was followed by the creation in 1994 of the NCAA Initial Eligibility Clearinghouse in Iowa City, Iowa. The Clearinghouse creation was done so it could be a used as a national center for determining initial eligibility for all NCAA Division I and II institutions thus removing the initial eligibility certification process out of the hands of member institutions themselves. The Clearinghouse initially used the 1991 
Proposition 42 standards in 1994 to determine initial eligibility for all incoming prospective freshman student athletes before adopting the sliding scale in 1996 (Britz, 2001). To counter the perception and reality that having individual institutions determine the 11 core-courses still left room for abuse within the initial eligibility system, the NCAA President's Commission enacted the creation of the Clearinghouse. Prior to the creation of the Clearinghouse, different institutions, some under pressure from alumni and coaches could conveniently change a basic math course into a core-course with the stroke of a pen (McMillen, 1991). The changes in 1996 also gave the authority in determining a core-course to the high school principal and not to the individual colleges and universities (Britz, 2001). The standardized test scores were modified to take the composite scores of all functional areas of the test (Math, Reading, Social Science, Physical Science on the ACT test and/or the verbal and math sections of the SAT test), to give a prospective student athlete a chance at meeting the standard if they need to take the test several times. It basically combined the scores of several tests taken, coupled with a sliding scale to broaden the chances of meeting the requirements for initial eligibility and predicting academic success in college and to counter racial bias perceptions (Britz, 2001; NCAA, 2001).

The use of standardized tests for initial eligibility in 1986 up to the current re-centering of SAT scores and the use of composite ACT scores in 1996 has undergone many changes (NCAA, 1986, et al.). Sperber (1986) noted to meet the standard first established in 1986 to gain initial eligibility by scoring a 700 on the SAT, a prospective student athlete would only need to gain 200 points by signing his or her name and answering one question correctly. To then get the rest of the points needed to gain 700 , a prospect must only answer 13 out of 60 math questions and 24 out of 85 verbal questions correctly. This equates to an average of $25 \%$, compared with a usual accepted standard of $60 \%$ for minimal test passing standards in high schools and colleges 
nationwide. Very similar minimal standards applied to the ACT exam. Many athletes, coaches, administrators, and the NCAA itself thought that Proposition 48 and its future enhancements would keep many athletes from gaining admission (McMillen, 1991). In fact only 10\% of incoming freshman football and $13 \%$ of incoming basketball freshmen student athletes were deemed ineligible (McMillen, 1991).

The National Center for Education Statistics ("Who can play,"1995) research supported other research evidence that there was indeed a more dramatic decrease of competitively eligible student athletes since Proposal 16 was enacted. The report stated that $83.2 \%$ of all college-bound high school seniors in 1992 would have met Proposition 48 requirements, but only 64.7\% actually made the Proposal 16 standard even though it was designed to assist more individuals with the sliding scale. These conclusions are also supported by a report by the advocacy group Fair Test (Rooney, 1998) that concluded in 1995 that Proposition 48 and Proposal 16 completely ignore a large body of data showing that arbitrarily mandating higher test scores is not the same as admitting capable students. Fair Test's conclusions argue that high school performance is the best method for college admission and that standardized tests add little useful information to the high school record. Their research noted that 280 universities nationwide admit some or all of their applicants without regard to SAT/ACT scores, increasing diversity and academic quality of their entering classes (Miller, 1995; Rooney, 1998). The NCAA Research Report 97-03 (1998) conceded that fewer prospective student athletes were eligible for competition due to initial eligibility standards, but that existing graduation rate data at the time showed that academic performance while in college increased for those who did meet the standards.

Sperber (1990) also stated in his book, "College Sports, Inc., ” a publication that mocks the standards and initial eligibility requirements of intercollegiate athletics prior to 
1986, states that, before 1986, the only NCAA rule on the books for eligibility for an athletic scholarship since 1972 was to carry a high school grade point average of a 2.0 on a 4.0 scale. This was the only other standard used after the 1.6 rule (Byers, 1991). Sperber also noted that the lax attitude toward academics starts at a young age with promising athletes. In "College Sports, Inc., " former major league standout pitcher Jim Bouton said in response to this standard, "Your outstanding jock has technically been on scholarship since the third grade" (p.279). Sperber (1986) added that the outstanding athlete has more often than not been coddled academically and has received special treatment from teachers and classmates along the way during the primary and secondary educational years, most often a $\mathrm{C}$ average was zero proof of his or her academic qualifications of aptitude for higher education. Keeping in mind, the 2.0 average said nothing about successful completion of college-prep or core-course classes and acceptance of any high school transcript, which was left up to the institution that may or may not be getting outside pressures from coaches, parents, the media, and even college administrators.

\section{History of Tracking Graduation Rates of NCAA Division I Student Athletes}

A possible solution in testing the effects of the initial eligibility standard is having a standardized graduation rate assessment report to ascertain if the standards are increasing the likelihood of student athletes graduating (McMillen, 1991). Once the higher initial eligibility standards were implemented, it became legislated by the NCAA in 1990, under pressure from the United States Congress, that each institution must report and have publicly distributed graduation rates by 1991 (McMillen, 1991). Later in 1990, The Student Right-to-Know Act mandating graduation-rate and financial data for all colleges became law (Lederman, 1991). According to McMillen (1991) and Lederman (1990), the impetus for the Student Athlete Right to Know Act was the advent of stricter, national, initial eligibility standards for incoming freshman student 
athletes that would raise their graduation rate. The NCAA national office, based in and around Kansas City, Missouri until its move to Indianapolis in 1999, conducted several studies that show that the initial eligibility standards have indeed raised the graduation rates for student athletes every year since 1990 and thus in total is an effective predictor of academic success in college (Benson, 1994; 1997). These same studies show the student athlete graduating at a rate higher than the overall general student body at most institutions (Lederman, 1990).

Three elected officials, two congressmen and one senator (Tom McMillen, D-MD, Senator Bill Bradley, D-NJ and Ed Downs, D-NY) along with other proponents for the bill that became the Student Athlete Right-to-Know Act, were supported by the 1991 Knight Foundation Report. The Reports of the Knight Foundation Commission on Intercollegiate Athletics (1991, 1993) were a series of reports drafted by athletic directors, other concerned administrators in higher education, politicians, and corporate executives, publicly came out the same time the bill was being debated on the floor of the House and Senate. The Knight Commission Report is viewed as the single most important document ever written about intercollegiate athletic reform (Byers, 1995; McMillen, 1991, "The Crisis," 1990). This report was graphic in its detail on the abuses of intercollegiate athletics, specifically academic abuses and the dearth of student athletes graduating from college. The Knight Commission's report assisted the Student Athlete Right to Know Act in getting enough backing throughout congress to become law in 1991 as part of the Campus Security Act (“The student athlete," 1991). This act required all Division I and II universities to annually publish the graduation rates of all student athletes by sport, by gender, and by ethnic background. The difference in the NCAAs graduation report format from other one-shot graduation rate studies done in 1988 by the General Accounting Office and The Chronicle of Higher Education is that the data would be taken over a six-year period to better 
ascertain the institutions commitment to graduating student athletes, even after athletic eligibility had already expired (McMillen, 1991).

Statistics on athletes who participate in college sports and who graduate or do not graduate are useful because they help shape a picture of the athletic experience and because it has evolved as the main measure of student athlete success or failure for NCAA member institutions (Watt \& Moore, 2001). Since 1983, even before the Student Athlete Right to Know Act, the NCAA was sporadically collecting graduation rate data on student athletes. Since 1983 the graduation rate of student athletes has improved over time (Benson, 1994, 1997; Zimbalist, 1999). Since 1991, the first year of the Student Athlete Right to Know Act, the NCAA has reported higher graduation rates for student athletes as compared to the student body every year since (Benson, 1994, 1997; Zimbalist, 1999). However, in the past two decades $42 \%$ of student athletes overall still have not graduated from college (Benson 1994, 1997; Watt \& Moore, 2001). The literature identifies many academic and non-academic variables as predictors of the dependent variable-graduation rates of student athletes. The seven independent variables most often identified in the literature to have a significant effect on the dependent variable of graduation rates of Division I student athletes are gender, ethnicity, high school core-course grade point average, score achieved on a college entrance examination (ACT or SAT), what sport played in college, student athlete's perception of college coach's emphasis on academics while in college, and the integration and use of specialized academic support services for student athletes (Adler \& Adler, 1985; Benson 1991, 1994, 1997, Purdy, Eitzen \& Hufnagel, 1982; Hoyt, 1968; Nicholson, 1973, Richards, Hollands, \& Lutz, 1966; Summers, 1991). 
Previous Research on Graduation Rates of NCAA Division I Student Athletes

Since the academic reform movement of 1984 that led to the approval of an increased national initial athletic eligibility standard in 1986, graduation rates for all student athletes have increased dramatically according to NCAA research and published athletic graduation rate data. Most research states there has also been a marked increase in Division 1-A athletic programs graduation rates versus the graduation rates of the general student body at Division 1-A institutions (Benson, 1994; 1997).

According to the 1995 NCAA Division 1-A Graduation Rates Summary (1995), national initial eligibility standards have shown to affect an increase in student athlete graduation rates every year since 1984. Student athletes entering college in 1984 and analyzed using 1990 as their graduating year, graduated at a rate of $52 \%$, while the general student body graduated at a rate of 53\%. Student athletes entering college in 1988 improved up to 58\% while the student body graduation rate for the same time period was 57\%. Another recent NCAA Graduation Rates Report (1999) for student athletes entering college in 1992 shows student athletes graduating at an all time high of $58 \%$ while the general student body is at $56 \%$. The two high profile sports of men's basketball and football have shown similar increases since 1992 culminating in a $41 \%$ graduation rate for men's basketball and a 51\% for football in 1999, but these two sports are still below the overall student body average. This was the seventh consecutive class that has met higher initial eligibility standards set by Proposition 48, and later Proposition 42 and Proposition 16. The NCAA graduation rates, by the NCAA research staff's own admission, are conservative estimates because some student athletes may not actually be counted in the data. Only student athletes, who enroll as freshmen, receive athletically related financial aid, and graduate from that 
institution within six years of initial enrollment are tracked (Benson, 1994, 1997; Jankowski, 1999, NCAA, 2001).

Underwood (1984) wrote that graduation rates have not always been as easily accessible as the NCAA reports. Some prior research shows that athletes have consistently graduated at higher rates than the general student population, even before the enhancement of initial eligibility standards. Bowlus (1975) conducted a study to assess the impact of a college education on athletes and non-athletes following their graduation from Indiana University. He found that student athletes had consistently done as well or better than non-athletes in their ability to earn a living because of their education. The American College Testing Program (ACT) conducted a study in 1968 on male student athlete graduation rates. The study showed that $52 \%$ of the male student athletes graduated while $41.5 \%$ of the non-athletes had graduated. The study stated that if there was a problem with a low graduation rate, it was because student athletes left college early to start a professional career, not because of being academically unprepared (Underwood, 1984).

These early studies do not take into account whether the student athletes actually did the work required to obtain a degree. While there had been encouraging signs of increases in the graduation rates of student athletes, other studies showed that many universities had embarrassingly low graduation rates for their student athletes. Knight Commission $(1991,1993)$ surveys show 35 Division 1-A schools had graduation rates under 20\% for their basketball players and 14 had the same low rate for their football players. In a study completed by Higher Education Daily, the University of Southern California admitted that only a few of their marginally admitted student athletes ever graduated ("USC Confesses," 1980). The National Assessment of Academic Progress (1983) claims that this type of low graduation rate need not exist and that it can be eliminated by raising the expectation level for marginally admitted 
student athletes. Former professional tennis player and civil rights advocate, the late Arthur Ashe, clearly believed in his book, Days of Grace (1993), that raising academic standards early in one's scholastic career, especially for minorities, enhances their ability to graduate from college and become productive, better prepared citizens.

Existing research strongly evinces that increased academic preparedness at the primary and secondary levels of education prior to college enrollment has given student athletes a better background in preparing for college-level work and graduating at higher percentages than ever before (Benson, 1993, 1994, 1997; McMillen, 1991; Zimbalist, 1999). NCAA research states that prior to Proposition 48, the overall graduation rate for student athletes was similar to non-athletes (Benson, 1993). The research also shows a marked improvement in the graduation rate as standards were raised and modified up to the current level (Benson, 1994, 1997). Current NCAA Executive Director, Cedric Dempsey, said in 1995, that in general, the NCAAs efforts to increase academic standards for incoming student athletes are having a positive effect throughout their academic careers, as demonstrated by the improvements in their graduation rates (Reith, 1995). Other Student Athlete Graduation Rate Research

There is research that contradicts initial eligibility standards increasing the graduate rate of NCAA Division I student athletes. According to the Report of the McIntosh Commission on Fair Play in Student athlete Admissions (1994; Blum, 1995), the Commission feels that initial eligibility standards are flawed by their unethical reliance upon arbitrary test score cut-offs instead of genuine measures of capacity to do college-level work. The 15-member group, that included 11 college professors, two officials from a national firm the monitors the reliability and validity of standardized tests, a high school coach, and a member of an educational consulting firm, feels this actually interferes with the educational progress of student athletes ("Panel says," 
1995). This report goes on to promote the NCAA Research Staff's own conclusions that the use of any fixed minimum on any single indicator is not psychometrically sound. The McIntosh Commission recommended using a true sliding scale, which would allow test scores lower than the current minimums providing there is a corresponding higher grade point average, basically eliminating a true minimum test score or GPA in all instances. It also goes on to recommend that each individual institution should determine who gains admittance and competes in varsity athletics or many prospective student athletes, especially ones from low-income families and minorities, may be eliminated from getting an opportunity due to NCAA minimum eligibility standards when they may have otherwise been likely to graduate from a four-year institution (“Panel says," 1995).

\section{Predictors of Student Athlete Graduation Rates} Student Athletes Perception of College Coach's Emphasis on Academics

Student athletes are selected and recruited by coaches. These same coaches work with them and get to know them well while they are enrolled in college. If a student athlete runs into personal or academic trouble, coaches are usually nearby, ready, and motivated to help. In helping to advance their own careers, the coaches must recruit good athletic material and then guide these students through successful academic and athletic careers (Thompson, 1991). A coach can be the strongest support person in the life of a college student athlete (Petrie \& Russell, 1995). Adler and Adler $(1988 ; 1991)$ found that the varied sets of educational and life goals with which players entered college rapidly shrank to the single goal of winning games by a process they call "role engulfment." They noted many factors contributed to this narrowing of aspirations, but found that the coach was the main influence in intentionally orchestrating the process of role engulfment away from academics in order to obtain the extreme loyalty from 
players he believed he needed in order to meet high performance athletic goals. Coaches can be an intended or unintended source of intense reinforcement for the role of a winning athlete but a lack of reinforcement for the academic role (Briggs, 1997).

Researchers have attempted to determine what non-academic variables might help to explain the college academic performance of student athletes. The non-cognitive variables of a strong support person, involvement in the community, and positive self-concept positively predicted college academic performance. If influential role models do not care how the student athlete performs academically, the student athlete's academics will suffer (Broadhead, 1992; Petrie \& Russell, 1995; Sedlacek \& Adams-Gaston, 1992; Sellers, 1992; Young \& Sowa, 1992). Many coaches themselves favor making the coach and athletic department responsible for the graduation rate of student athletes and stressing more the importance of education and graduation to the student athlete (Cullen, Latessa, \& Byrne, 1990).

However, many student athletes have been counseled by coaches to major in eligibility (Purdy, 1981). Several former student athletes at different California State Universities and Colleges claimed that coaches advised them to enroll in courses like physical education courses to protect their athletic eligibility. In some cases, students were instructed to reenroll in courses they have already passed and coaches became upset when players took courses that were required for graduation instead of courses that helped maintain eligibility (Broadhead, 1992). Revenue sport student athletes typically take a downgraded curriculum often at the insistence of their coaches and designed specifically for them, which could significantly reduce the educational value of their time in college (Adelman, 1990; Adler \& Adler, 1991, Briggs, 1997; Purdy, 1981). Student athletes will often decide in favor of athletics when a conflict exists with academics (Adler \& Adler, 1991) to please their coach who possesses the power to decide who 
starts in games and who is put on scholarship (Simons et al., 1999). In non-revenue sports, coaches typically do not put much pressure on non-revenue athletes to perform. Since winning in revenue sports appears to have a larger monetary effect, it is believable that those athletes are forced by coaches to accept a more severe tradeoff between academic performances relative to athletic achievements (Maloney \& McCormick, 1992).

According to Adler and Adler (1998) and Briggs (1997), the goal toward which a coach rallies the athletes, and around which he forges their role identity until it becomes their central life interest, is extremely short term. As one ball player explains, "Coach's main goal is to keep producing quality basketball teams... His job is not to produce accountants or NBA athletes, it's to have a winning program" (Briggs, p. 412).

The Use of Specialized Academic Support Services for Student Athletes

Many institutions provide extensive academic support services to intercollegiate athletes (Briggs, 1997). Shinberg and Brodzinski (1984) state that in the early 1980s athletic administrators and other higher education professionals began to view intercollegiate athletes as a special population with unique academic concerns. Critics say that graduation rates of athletes are inflated because of these specialized academic support services for athletes and many would not graduate without an inordinate amount of help (Naughton, 1997). Thomas L. Haskell, a professor at Rice University, said that athletes are shepherded through courses and majors that athletic academic counselors know they can pass, rather than receiving an authentic education. He argued that if athletes were real students, they would not need elaborate and costly machinery to do what normal students must do as a matter of course (Naughton, 1997). Critics of intercollegiate athletics point out that initial eligibility standards alone do not increase graduation 
rates. They point to a vast array of services available to only athletes that can insure that even a marginal academic student athlete can graduate (Sperber, 1990).

Many prospective student athletes, who meet NCAA Clearinghouse standards for competitive eligibility, still do not meet admission standards for a particular university. This subgroup may be admitted to a university under a special exception and typically may need assistive academic services available only to student athletes to attain graduation (Benson, 1994). Most Division I universities offer admission exceptions to get athletes into school, even if the student athlete is under prepared and not ready for the academic reality of college work. With the exception of true scholar athletes, academic averages and test scores of recruited athletes are well below those of students admitted for their academic performance (Greene, H. \& Greene, M., 2001). The sheer competitive nature of athletics and the desire to get the best athletes can persuade coaches to just look for the best athletes and not the academically oriented ones. Looking for loopholes in admission requirements to get even non-qualified athletes admitted goes on everyday at institutions of higher learning (Blum, 1994; Naughton, 1997; Sperber 1990). Student athletes have almost twice the chance of being accepted to the college of their dreams, although this dream may be based solely on athletic reputation and a persuasive coach (Greene, H. \& Greene M., 2001). Several college admissions directors advocate the opportunity given to all students in college and the risk that goes with admitting any student who does not meet the institutional requirements. They also weigh that opportunity with the risk and the reward of knowing not all will make it, but hope that most will take advantage of the opportunity (Blum. 1994).

Even with student athletes meeting initial academic standards and getting admitted, practice, competition, and the rigors of academic and athletic life in college can also present 
difficult challenges for even the academically successful student athlete (Naughton, 1996).

Student athletes at the intercollegiate level must abide by an abundance of NCAA rules, be treated as any other student, and, in general, receive the same benefits that are available to the institution's students or their relatives or friends (NCAA, 2000). The reality is that student athletes are treated differently from the rest of the student body at most higher education institutions. Student athletes at virtually all NCAA institutions receive compensatory academic assistance. Most institutions offer athletes an array of advisors, tutors, and mentors to help them learn how to balance the demands of the classroom and the playing field while it labors to educate the ones who may not be as well prepared academically as their classmates (Naughton, 1997; Suggs, 1999).

Services available are usually in the form of a dedicated academic service center solely for use by the athletes at the institution. These centers are sometimes located within athletic departments, and offer equipment and services that in many cases are superior to what the institution offers the rest of the student body. The administrative oversight, while mostly performed by the athletic department, can fall under an academic entity. Many recent academic scandals have prompted more universities to bring all academic advising for student athletes under the control of an outside academic department to insure better administrative oversight (Suggs, 1999). Many higher education administrators believe that it makes it less likely for academic integrity to be questioned if a student athlete academic center reports to an academic department (Suggs 1999).

Initially, isolated academic services for student athletes included only class scheduling, tutoring, and time management assistance (Broughton \& Neyer, 2001; Shinberg \& Brodzinski, 1984) unlike current dedicated academic centers or even buildings solely used for academic 
assistance to student athletes. These centers provide, in addition to academic counseling, a counselor to student ratio at a much better ratio than the general student body, tutoring, advance scheduling, drug and alcohol counseling, study and academic skill sessions, and life skills classes (Naughton, 1997). Critics of these types of arrangements argue that the necessity of these support services suggest many athletes, especially those in football and men's basketball would not succeed without an inordinate amount of help. Those who support special services for student athletes say all college students in general need these programs and athletic academic assistance programs are available for other students throughout campus (Naughton, 1997). These services are more concentrated in athletics, with the main reason being because the student athletes' time is so limited due to complex demands that result from participating in competitive sport (Broughton \& Neyer, 2001; Naughton, 1997). Some educators fear that this type of academic assistance has created a culture that makes athletes not real students because athletes are shepherded through courses academic counselors know they can pass rather than receiving an authentic education. They question the use of the elaborate and costly machinery required for them to do something that is a matter of course for the rest of the student body (Naughton, 1997).

Increased compensatory academic assistance as this has been cited as a reason, along with better pre-college preparation, for increased graduation rates for student athletes since 1991 (Benson, 1997). Fred Strook, a former president of the National Association of Academic Advisors for Athletes, attributed the relative success of student athletes in the classroom to an increased commitment to academics at Division I institutions. He also believed that, in general, student athletes have a lower academic profile than the typical student, but in the last fifteen years almost every Division I school has put in athletic academic programs in academic 
counseling, tutoring, mentoring, and programs in career and life skills to assist in providing the opportunity for an athlete to be successful athletically and academically. (Naughton, 1996).

The overall increase in graduation rates, in surveys done by the NCAA since 1991 show that the increased initial eligibility standards combined with a long list of academic services for Division I athletes have contributed to the overall increase in the graduation rates of student athletes (Benson, 1997). The NCAAs official stance is that part of the increase is due to initial eligibility standards and student athletes being watched closely academically through their athletic academic services department during years of enrollment (Lederman, 1992). George Raveling, a former head men's basketball coach at the University of Southern California, Iowa, and Washington State University echoed the fact that just getting into college does not guarantee a degree or show that a person is capable of doing college level work. He noted that academic services are essential and vital to the success of the student athlete, but that it is difficult to accept a student not graduating with the type of assistance that is available at most Division I schools. "I think you have to work at not getting a degree if you are a student athlete today" (Lederman, 1991, p. 2).

Sport Played in College

College football and men's basketball teams may constitute a campus sub-culture that attaches less value to academic achievement than do other sports (Pascarella, et al., 1995; Richards \& Aries, 1999; Sedlacek \& Adams-Gaston, 1992). Universities are often concerned with their athlete's eligibility status because of the tremendous revenue the athletic programs produce in football and men's basketball particularly. In order to remain solvent, the university must deliver a winning team in these two sports. To deliver a winning team, keeping the athletes eligible, as opposed to on track for graduation becomes imperative (Broadhead, 1992). There is 
evidence in the literature that participating in intercollegiate athletics can have a positive effect on graduation rates, as long as the sport is not football and men's basketball. Even if a student plays one of these sports, playing an additional sport seems to moderate the negative effect on the graduation rate usually found in these two sports (Briggs, 1997). The conflict of being a student and an athlete is greatest in the revenue sports of football and men's basketball (Leonard, 1985; Sack \& Thiel, 1985; Richards \& Aries, 1999) and those students enter with typically marginal academic backgrounds and choose less demanding college majors (Adler \& Adler, 1985; Mayo, 1982; Sack \& Thiel, 1985).

Most student athletes start college with the same degree aspirations as other students, but after four years of college, football and men's basketball players have a significantly lower degree attainment and degree aspirations those counterparts who play other intercollegiate sports at the start of college enrollment (Briggs, 1997). The level of degree aspiration drops significantly more after being enrolled in college for one year (Briggs, 1997) due to these athletes being the most highly recruited and receiving more extrinsic rewards in the areas of publicity and social support (Simons et al., 1999). Pascarella, et al., (1995) studied a random sample of student athletes at two and four year institutions and found that football and men's basketball players showed net losses during the freshman year on standardized tests of reading comprehension and mathematics, while students in other sports and non-athletes made modest gains. In 1997, only one top-25 ranked school in both football and men's basketball, The University of Texas, had an overall higher high school grade point average than that of the freshman class as a whole (Benson, 1997). Only $40 \%$ of men's basketball players who entered NCAA Division I colleges in 1994-95 earned their degrees within six years, the lowest rate of any class since the NCAA toughened its academic standards for incoming athletes in 1986. Of 
the 298 institutions playing Division I basketball, 104 failed to graduate a single player in the 1994-95 cohort. In football, only 28 of the 50 teams that played in college football bowl games graduated more than $50 \%$ of their players (Suggs, 2001). Critics of college athletics feel that the pool of students who excel at academics and athletics is too small to fill their men's basketball and football rosters with players who meet typical admissions criteria. It is estimated that each year out of 1500 top-level college football recruits, there are only about 300 who score above 1050 on the SAT test (Sperber, 1990).

Initial eligibility non-certifications through the NCAA Initial Eligibility Clearinghouse are more prevalent in the sports of football and men's basketball ("Study shows," 2001). Among the 106 institutions classified as Division 1-A in the decade of the 1980's, 48 had graduation rates under 30\% for their men's basketball players and 19 had the same low rate for football players (“A Call to Action,” 2001). The 2000 NCAA Graduation Rates Survey (2001), using a cohort from the entering class of 1994 , reveals that only $48 \%$ of Division I-A football student athletes and 34\% of men's basketball players that enrolled in the fall of 1994 earned degrees.

Athletes in these two sports virtually become celebrities on campus and surrounding communities. Students, professors, and administrators admire them. Football and basketball programs at Division I institutions attract on average more highly skilled players, give those programs greater campus and public visibility, and invest and generate larger sums of money. Athletes in the sport of men's basketball generally receive more positive reinforcement and accolades for their athletic performance rather for their academic achievement, and that can shift their priority away from academics toward athletics (Adler \& Adler, 1985; Eitzen \& Purdy, 1986). 


\section{Examples of Sport Played in College Affecting Graduation Rates and Academic Achievement}

Many colleges and universities fell victim to the win at all costs mentality and decided to stretch the limits of institutional integrity for athletic gain and profit (Byers, 1995; McMillen, 1991). One case includes the sad story of Dexter Manley, a former professional football player who attended Oklahoma State University. Attended might be a strong term for what really happened during Manley's academic career. Near the end of his professional playing days, and after numerous drug rehabilitation stints, Manley appeared before a United States Senate subcommittee on illiteracy. Manley tearfully told the panel that despite his four years at Oklahoma State, he had neither graduated nor learned to read. However, he managed to play four years of college football and achieve All-American status. Senator Barb Mikulski of Maryland commented indignantly, "You didn't fail sir, the system failed you" (Byers, 1995, p. 298; McMillan, 1991; Sperber, 1990).

The failure of the system was becoming evident as many more cases like Manley's surfaced. Student athletes without any basic academic preparation or skills were being admitted to colleges and universities by the hundreds with no end in sight. In 1983, an anonymous Iowa State University academic counselor said that $10 \%$ of the institution's football and men's basketball players were "functionally illiterate." The counselor defined this standard as reading below the fourth grade level. The counselor goes on to say that $95 \%$ of the student athletes in the department read at or below the tenth grade level. He also contended that this was status quo within many other major athletic programs and that numerous athletic programs do not test the athletes' reading ability because they do not want to know how illiterate some of their athletes are (Sperber, 1990). Intercollegiate football and men's basketball players typically have lower end of freshman year average reading comprehension and mathematics scores than their 
counterparts who either played other intercollegiate sports or were non-athletes while there is a general parity between male athletes and non-athletes in non-revenue sports (Pascarella, et al, 1995).

Even individual university admission standards were, and in some cases still are, easily manipulated through special admittances (Sperber, 1990), especially in the sports of football and men's basketball. Several schools in the nation admit at least a small percentage of applicants who do not meet the regular admission standards (Sperber, 1990). The intent is that while this student may be weak in one area, like math, he or she has the potential to succeed in college. Prior to the advent of national initial eligibility standards, many universities became "jock factories" that used the special admit loophole to their advantage. Schools routinely admitted students based on their athletic, not academic ability (Sperber, 1990). On this basis alone, the athlete is offered a scholarship and most likely admitted to the institution. One anonymous college coach even remarked, "We don't need any more students, we have a sufficient number of National Merit Award winners, what we need are more athletes at this institution" (Underwood, 1984, p. 21). The athletic department usually negotiates this with the admissions office and some coaches even have this stipulation augmented by a specific number written into their contracts. Underwood (1984) also felt coaches should be eliminated from the admissions process and only make a preliminary evaluation to see if the prospect can meet existing institutional standards, and not look for special admits loopholes based on athletic ability.

Notable special admits prior to the radical initial athletic eligibility reform of 1986 were Manley and men's basketball player John “Hot Rod” Williams from Tulane University. Williams had a 470 cumulative SAT score compared to the mean freshman cumulative SAT score of 1121 at Tulane. The University's internal investigation into this matter, and an ensuing point-shaving 
scandal in which Williams was the impetus, led to the institution eventually dropping the onceproud basketball program for one year in 1990 (Byers, 1995). Chris Washburn, the number one high school basketball player in the nation was admitted to North Carolina State University in 1984 with an identical score of 470. After a media expose on the recruitment of Washburn and his admission into North Carolina State, Bruce Polton, the Chancellor of the University said that the institution admitted Mr. Washburn because they honestly thought and believed he could do the work required of a college student (Byers, 1995). The expose, led by Sports Illustrated Magazine, eventually led to an NCAA investigation of the North Carolina State men's basketball program. Polton later resigned amid the controversy over charges that university management was subservient to head men's basketball coach Jim Valvano in the matters of admissions and the boosting of athletes college grades. The Chris Washburn situation led to the downfall of Valvano and the championship caliber North Carolina State men's basketball program (Byers, 1991, McMillan, 1992, Zimbalist, 1999). Byers (1991) and Zimbalist (1999) also reported on the case of former Creighton University men's basketball player Kevin Ross, who could not read but was allowed to play by University administrators. Ross actually sued Creighton stating that the University should have known he was ill equipped and unable to successfully participate in the University's academic program and that Creighton University failed to educate him adequately. Ross had an ACT score of 9 compared to the mean ACT average of 23.2 for incoming freshman at Creighton. He was granted a special admission exception by an academic vice-president, a frequent recourse by most colleges at the time, and was allowed to play basketball (Broadhead, 1992).

Athletes in the sports of football and men's basketball are continually being admitted to colleges and universities without being academically prepared for the rigors of college level 
work (Sperber, 1990; Lapchick \& Slaughter, 1989). Besides not being prepared for the level of academics in college because of a poor primary and secondary education and/or being coddled by the system due to their athletic ability, these student athletes were not graduating (Broadhead, 1992). Lapchick and Slaughter (1989) stated that although athletes statistically perform better than non-athletes in high school, the vast majority of problems occur in men's basketball and football, which stand far above the others as sources of huge revenue and notoriety for athletic departments and institutions alike. The trend of athletic departments tossing aside athletes who have finished their eligibility but had not yet graduated became commonplace. The Dexter Manley and Kevin Ross cases are prime examples of this tragedy. The strategy of like-minded reformers in the early 1980s to improve on this widespread functional illiteracy of athletes was to study trends and determine why academic abuse within intercollegiate athletics was a problem. The illiteracy rate for high school football and men's basketball players was estimated in 1989 to be as high as $30 \%$. This was more than twice the national illiteracy average for high school seniors. Also, in 1989, only $27 \%$ of men's basketball players and $30 \%$ of football players who enrolled in 1984 actually graduated from college (Slaughter \& Lapchick, 1989).

\section{Ethnicity}

African-Americans constitute the largest proportion of student athletes on athletic scholarships in Division I ("Vital Signs," 1993-1994). There is little literature available on other student athletes of minority races concerning graduation rates, (Person, Benson-Quaziena \& Rogers, 2001). In every student athlete sub-group, African-American males lag far behind in student athlete graduation rates (“The Academic Performance," 2000). Ethnicity is a variable likely to influence both a student's educational achievement and also what sport he or she plays (Adleman, 1990; Astin, 1993; Pascarella \& Smart, 1991; Pascarella, et. al, 1995). Some minority 
groups, specifically African-American males, suffer from an educational system that is not developed optimally for minorities (Ting \& Robinson, 1998). According to Sedlacek (1996), standardized tests that are used for admission to higher education institutions focus on intelligence areas that minorities typically do not develop, but are prevalent in male and female Caucasians. On average $51 \%$ of black males and $60 \%$ of black females usually score less than 700 on the SAT (Clark, Horton, \& Alford, 1986) and ACT and SAT scores are generally better predictors for non-minority student athletes (Petrie \& Russell, 1995). A 2001 NCAA Initial Eligibility Clearinghouse study examining the incoming 1997 and 1998 freshman class of student athletes found the constituency most affected by being ineligible was African-Americans (Benson, 1998). In particular, there continues to be a great debate over the impact of participation in intercollegiate athletics, particularly in the sports of football and men's basketball on students' educational and career development, especially for African-American, other minority, and low-income students (Briggs, 1997). The 2000 NCAA Graduation Rates Report (NCAA, 2001) states that 41 Division I institutions failed to graduate any black male athletes in the sport of men's basketball over a six-year period, including six teams that played in the 2000-01 NCAA Men's Basketball Championship (Suggs, 2001). The primary reason for the higher rates of intercollegiate athletic ineligibility has been the failure of a high percentage of African American prospective student athletes to meet the minimum test score requirement (“Study shows," 2001).

Overall, less than $20 \%$ of all black male athletes were ineligible and this was far less that the $62 \%$ predicted by the NCAA national office in the first year of Proposition 48 (Lapchick, 1989; "The Crisis," 1990). Civil rights activist and Stanford University professor Harry Edwards noted the NCAAs own research predicted even a possible $80 \%$ ineligibility rate the first year. 
Edwards, who is black, felt at the time the standards were still too low because it stressed only minimum achievement, but he saw it as a step in the right direction. He added, "It is going to communicate to a generation of black athletes that we expect you to perform academically as well as athletically" (Lapchick, 1989, p. 16). The proportion of black athletes entering college did fall to $18 \%$ the year after Proposition 48 took effect, but the rate climbed back to $22 \%$ by the fall of 1998 (Padilla \& Walker, 1994). The higher standards also initially resulted in fewer minority students graduating from college (Klein \& Bell, 1995). The NCAAs Director of Research, Ursula Walsh, stated in 1994 that because of Proposition 48 and ensuing legislation, blacks are graduating at a higher rate numerically and proportionately than before Proposition 48 took effect, but fewer black males appear to be attending college and seeking to participate in intercollegiate athletics (Blum, 1995; Witham, 1995).

\section{Gender}

Gender is also a variable likely to influence both a student's educational achievement and also what sport he or she plays (Adelman, 1990; Astin, 1993; Pascarella \& Terenzini, 1991). The literature consistently shows that female student athletes are superior to male student athletes in high school grade point averages, entrance exam scores, and college grade point averages, and are more able to balance the academic and athletic role in college (“American Institutes for Research”, 1989; Purdy et al., 1985; Simons, Van Rheenen \& Covington, 1999). Female student athletes are also less likely to attend college for the main purpose of playing sports because of the lack of extrinsic rewards and the possibility of playing professional sports (Simons et al., 1999). A 1981 survey by the NCAA and the American College Testing Program of non-athletes and athletes from 1975-80 showed a greater tendency 
for male athletes to still be enrolled in college after five years than female athletes or nonathletes who typically graduate during that time period (Nikou \& Dinardo, 1985).

Male intercollegiate football and basketball players tended to have significantly lower levels of second-year writing skills and third year critical thinking and reading comprehension skills than non-athletes and athletes in other sports. There is little empirical evidence of similar, broad-based negative cognitive impacts for women athletes during these periods (Pascarella, et al; 1999). The NCAA 2000 Graduation Rates Report (NCAA, 2001) showed only 25 of 65 , NCAA Men's Basketball Championship 2000-2001 Tournament participants, that graduated $50 \%$ or more of their players, while 53 of 64 women's NCAA Tournament teams graduated $50 \%$ or more of their players (Suggs, 2001).

Student athlete educational achievement, measured by grade point average in college and graduation rate is more likely among females than males (Purdy, 1981). Research results of freshman scholarship football players at Iowa State University randomly matched with male nonathletes showed that male and female non-athletes were significantly better prepared for college on high school grade point averages and test scores (Sedlacek \& Adams-Gaston, 1989). In 1988, there was a series of studies completed by the Chronicle of Higher Education and the General Accounting Office showing the abysmal student athlete graduation rates of many colleges and universities. Overall the studies showed that male student athletes were graduating well below the general student body with serious graduation gaps in the sports of men's basketball and football including the University of Nevada at Las Vegas which had graduated only $20 \%$ of its male athletes that year (McMillen, 1991). 


\section{High School Core-Course Grade Point Average}

The literature review revealed few studies that reported higher high school grade point averages for student athletes in any subgroup. Most of the studies reported lower high school GPA's for athletes than non-athletes (Cantor \& Prentice, 1996; Purdy et al., 1985; Simons et al., 1999). The issue of accurately predicting college students' academic performances and successes, often operationalized as grade point averages or retention and graduation rates, has become increasingly important to college counselors and administrators as researchers have questioned the validity of more traditional academic predictors (SAT/ACT test score or high school GPA) particularly for minority students who attend predominately white institutions (Nettles, Theony \& Gosman, 1986; Petrie \& Russell, 1995; Sowa, Thompson, \& Bennett, 1989; Tracey \& Sedlacek, 1984, 1985, 1987; Wilson, 1981). While research has cast doubt on the validity of the SAT and ACT being predictive of subsequent college academic performance, high school grade point average in college preparatory classes may be indicative of subsequent academic performance and presents a greater barrier to initial eligibility than the test score (Petrie \& Russell, 1995, Witham, 1995). According to the National Center for Education Statistics (NCES) ("Who can play," 1999), the entrance exam test scores were not the only reason for concerns of racial bias According to their research, not meeting the required corecourses was even more of a deterrent. NCES found that of all incoming student athletes in 1995, $87 \%$ actually met the test standard while only $75 \%$ had taken the required core-courses or attained a high school core-course grade point average to be certified competitively eligible their freshman year (Blum, 1995; Witham, 1995). In a study of incoming student athletes at a major university in 1981 only three percent of the student athletes admitted with high school grade point average less than 2.50 graduated (Purdy, 1981). 


\section{ACT/SAT Test Score}

Athletes have typically been admitted to universities while seemingly lacking the necessary background to do college level work (Lapchick \& Slaughter, 1989; Sperber, 1990). Operationally the score achieved on the SAT and/or ACT test has been used as a predictor for academic achievement in college (Purdy, 1981). A study of incoming student athletes in 1981 found that the score achieved on an entrance exam significantly predicts the ability to perform academically in college. The study found that only $18 \%$ of student athletes who scored less than 700 on the SAT graduated while only $24 \%$ of those who scored less than 15 on the ACT graduated (Purdy et al., 1981). A 2001 University of Minnesota Study, financed by The College Board, the organization the develops the SAT test, found that the SAT reliably predicts students academic performance not only as freshman, but also throughout college although the correlation decreases each year (Jacobson, 2001). The reliabilities of the ACT test, the high correlations between the ACT and high school grades, all indicate that the ACT battery is a typical measure of academic potential (Munday, 1965; Richards, Holland, \& Lutz, 1967).

The literature states that although an entrance exam appears to be a valid predictor of graduation for students, student athletes typically score lower on the test, therefore decreasing the likelihood to graduate from college (Benson, 1994; 1997). The literature also states that minorities, which would have been admitted under institutional standards or even initial Proposition 48 standards, have been eliminated from athletic competition primarily because of set entrance exam test scores required for competitive eligibility (Benson, 1993; 1994; 1997). Several reports show that these individuals then forego college altogether because the opportunity for athletics has been eliminated (Benson, 1993; 1994; 1997). A 1993 study done at Clemson University showed that athletes do not perform as well in college as non-athletes 
because of lower SAT scores and poorer academic preparation. In this study the SAT scores of incoming student athletes averaged almost 150 points less than the general incoming student population (Maloney \& McCormick, 1992).

A recent annual NCAA Initial Eligibility Clearinghouse study on the 1998 and 1999 incoming freshman student athlete cohorts showed the number of prospective student athletes being certified as eligible for competition during their freshman year increased. However, the main stumbling block for certification was the failures to meet a required ACT or SAT test score ("Study Shows," 2001). The percentage of ineligible prospective student athletes due to the test score in 1997 was $3.5 \%$ out of 50,170 in the cohort, while in 1998 it was $3.2 \%$ out of 48,888 in the actual cohort population surveyed. The ACT and SAT are generally better predictors of college academic performance for non-minority as opposed to minority student athletes due to inherent cultural bias of the ACT and SAT. Many incoming student athletes fall into minority and low socio-economic groups. This group generally scores lower on college entrance exams (Petrie \& Russell, 1995; Walter, 1987).

Theoretical Basis

When an individual chooses between alternatives which involve uncertain outcomes, the behavior is not only affected by preferences, but to the degree he or she believes those outcomes to be probable, or expectancy of those outcomes. The belief that a particular act will be followed by a particular outcome is the basic premise of Victor Vroom's expectancy theory (Vroom, 1964). In correlating this theory to a study of generalizing a Division I conference to the predictors, as described in the literature, of graduation from college, it is important to note that a student's degree aspirations at the time of college entrance are the most potent predictor of enrollment in graduate or professional schools (Astin, 1977). While student athletes may not 
achieve their full aspirations, it is reasonable to assume that aspirations, or motivation, are a prerequisite for achievement. University athletes typically are motivated to succeed in the athletic domain (Simons, et. al 1999), yet some student athletes seem to lack the same motivation in academics (American Institutes for Research, 1989). That is to say that students will not achieve a degree that they do not aspire to (Briggs, 1997) but fear of academic failure and commitment to athletic eligibility plays an important role in the motivation of a student athlete (Simons et al., 1999). Student motivation is considered to be a determining factor in academic performance and persistence (Geiger \& Cooper, 1996). Alonso (1993) defines motivation as variables that activate or guide behavior in a particular direction to achieve an objective.

The expectancy theory itself is basically concerned with the probability that increased effort will lead to a certain level of success using the conceptual model of expectancy, valance, and force. The concept of force states that a person will choose either the strongest positive or the strongest negative act. It can also be stated that this model attempts to capture motivational force to act by associating the expectancy of resultant outcomes and their individual valences. The concept of force dictates as the strength of an expectancy that an act will lead to an outcome increases, the effect of variations in the valence of the outcome on the force to perform the act will also increase (Vroom, 1964).

The cognitive model of Victor Vroom's expectancy theory directly relates to a predictive research study of determining factors that influence the graduation rates of Division I student athletes. The expectancy theory can assess student motivation and predict academic performance for student athletes by assessing the expectancy of the outcome of graduation. The valence model, which captures the perceived attractiveness of an outcome, can be best applied here to see what can motivate a student athlete to graduate. This can be measured in several ways including 
personal satisfaction, accomplishing a goal, better job possibilities, living up to family pressures and standards, and making money among many other possible variables. The force model then attempts to capture that motivational force influencing a person to perform an act (Vroom, 1964). The force model can explain that a student's motivational force to achieve academic success is explained by the attractiveness of non-attractiveness of the valences (Geiger \& Cooper, 1996). In their study, Geiger and Cooper (1996) found the student's surveyed valence was accurately predicted when associated with increased grades and the force model accurately predicted student's effort level decisions.

Applying the expectancy theory and studying the motivators that can lead to graduation of Division I student athletes is an important study to undertake to assess how to better prepare prospective and current student athletes for the academic rigors of college. The theory states in Work and Motivation (1964) that motivated individuals put forth the greatest effort, believe that effort will lead to good performance, and that good performance will lead to preferred outcomes. Finding the factors that motivate or predict accomplishment of a goal like graduation for student athletes is important in applying this theory to the study. It is a diagnostic tool to gain understanding as to what motivates. Oliver (1995) used the expectancy theory in her study Motivational Factors on Performance. She found that rewarding and communicating positive and negative outcomes increased motivation in academic performance along with also adapting the curriculum used to more real world situations. This study specifically found predictors and motivational factors in increasing the likelihood of better academic performance and that the expectancy theory is a workable diagnostic tool for teachers in understanding how to motivate students to perform well in school. 
There is evidence indicating that athletic participation is linked with satisfaction with the overall college experience and also increases motivation to complete one's degree, persistence in college, and actual bachelor's degree completion (Astin, 1977; Pascarella \& Smart, 1991; Ryan, 1989). Some researchers believe that raising minimum academic standards for athletic participation can provide motivation for a student athlete to work harder academically increasing the expectancy to get a baccalaureate degree (Simons et al., 1999). Isolating the variables of valence, expectancy, and force and then generalizing to the Division I student athlete populous to uncover and define what motivational factors and predictors can better enable an intercollegiate athletic administrator to better tailor programs to the academic well being of a student athlete. Factors to consider may include placing emphasis on academics through coaches to athletes in that the educational attainment of a degree for a student athlete must be held in high importance for the student athlete. Tailoring specialized academic support programs for just student athletes to assist those at risk who have a low reliability rate on the high school predictive variables of grade point average, standardized test score, and college prep courses taken. These programs can also be directed to specific sports that typically have low graduation rates and to all student athletes that have acute time constraints with being a Division I student athlete (Naughton, 1997). Other programs like realistic life-skills counseling and professional sports counseling can help enhance the motivation and expectancy of an individual student athlete to graduate.

Taking variables like this and applying the three stages of Vroom's expectancy theory can decipher what factors, if any, can lead to assist in better predicting the graduation rates of student athletes. In turn using these predictors and motivational factors could lead to higher graduation rates of student athletes if enhancing and/or manipulating these variables increase the predictability of ability for this group to graduate. 


\section{Summary}

Research on the predictors of graduation rates for NCAA Division I student athletes can guide university administrators as well as athletic administrators in developing an attainable academic profile for incoming prospective student athletes. Intercollegiate athletics throughout its history has tried to balance the academic realities with winning programs. One way of ascertaining if academics are kept in priority for student athletes is to analyze the graduation rates of that group. If graduation rates of student athletes are low, ascertaining appropriate college preparatory course requirements, the high school grade point average, and set ACT and/ or SAT scores can develop this profile. A university can also increase compensatory academic assistance for higher risk student athletes who fall in to a minority status or who play in a higher risk sport. A Director of Athletics can make graduation of student athletes a priority in high-risk sports like football and men's basketball. Coach's evaluations can reflect their commitment to academics and graduation, making graduation of student athletes a focus for a coach who may be preoccupied with winning.

Intercollegiate athletics have a role to play on college campuses. However, this role has many times been skewed to favor winning and athletic excellence over academic excellence. The pressures for university and athletic administrators to succeed athletically can be overwhelming. Pressure from wealthy and prominent donors along with the ticket buying public to have a successful athletic program can assist in athletics having a more prominent role over academics. This dichotomy has existed since the inception of intercollegiate athletic competition in the mid 1800s.

One area of concern for administrators and educators is the graduation rates of student athletes at a particular institution. The NCAA, university presidents, and athletic administrators 
are intent on determining factors that can predict and lead to college graduation for a student athlete. The basis of this study is to identify cognitive and non-cognitive variables that can be measured and used to predict graduation or non-graduation from college for an NCAA Division I student athlete. Once these predictors have been identified as potentially significant they can be utilized in a way to develop strategies, counseling, and support in creating an overall academic profile.

This study relates to research in educational administration in that involves aspects of an entire university. University administrators are required to develop goals and strategies that identify with the mission of the institution in providing a competitive athletic department that fits within the mission, but does not override it. The administrative theory developed by Gulick and Urwick (1937) clearly defined the necessary functions of planning, organizing, staffing, directing, coordinating, reporting, and budgeting (Haller \& Kline, 2001). Recognizing and implementing these functions in developing and maintaining an intercollegiate athletic department that enhances the graduation rate of student athletes is essential to the overall success and standards of the university.

Specific goals relating to the graduation rates of student athletes, as well as all students, must be primary to the mission, planning, and objectives of the institution. University administrators should be willing to recruit, admit, and eventually graduate only student athletes that have the predictability to perform college level work while being able to meet the rigors of being an NCAA Division I student athlete. The university must also be willing to support rigorous secondary school college preparatory course requirements and minimum standardized test scores for admission to an institution and for intercollegiate athletic eligibility. 


\section{CHAPTER III}

\section{Methodology}

The purpose of this study is to determine if the characteristics of race, gender, high school core-course grade point average, ACT and/or SAT score, what sport played in college, student athletes perception of coaches on academics, and the use of specialized academic support services for student athletes as described in the literature, can be generalized to NCAA Division I student athletes in the Mid-American Conference. The study examined senior athletes, as determined by their years of competitive eligibility completed, in the 13 schools of the Mid-American Conference (MAC). Data for this study were drawn from an independent survey, constructed by researching the literature, and developed by the researcher. The data include elements of the high school and college academic and athletic life of the student athlete. The study analyzes the student attributes and/or perceptions of college coach's emphasis on academics, the use of specialized academic support services for student athletes, characteristics of the specific sport played in college, ethnicity, gender, high school core-course grade point average, and results of the American College Testing Program Test (ACT), and/or the Scholastic Aptitude Test (SAT), with attempts to generalize the profile of the Mid-American Conference athlete with the characteristics presented in the literature.

\section{Population}

Data were obtained from selected student athletes at the 13 schools in the Mid-American Conference. The data incorporated items from a survey instrument distributed to senior athletes at the 13 schools during the 2001-02 academic year. The population for this study included undergraduate student athletes in the Mid-American Conference that are currently in their senior 
year of NCAA eligibility, or in their fifth year of enrollment after expiration of their eligibility $(\mathrm{N}=1430)$.

For purposes of this population, a senior athlete may not be a senior academically, but will be competing in their last year of competitive NCAA eligibility. Student athletes at NCAA Division I institutions are allowed four years of competitive eligibility within five years of enrollment (NCAA, 2001). A fifth year student athlete is still enrolled at the institution and has not yet graduated, but has exhausted the four allowable years of NCAA competitive eligibility. Some data items are based on the recollection of each individual as in the case of grade point average and score attained on the SAT and/or ACT. While recorded data could have been obtained, complete anonymity could not be guaranteed should that occur. The researcher believes these items are of such importance to an incoming freshman student athlete that the data recalled should be relatively close to exact. The predictors are assessed on the expectancy and predictability of graduation within a maximum of one academic year from the administration date of the survey instrument, based on analysis of responses completed on the survey and the percentage of degree completed by each individual. Percentage of degree completed is used as an NCAA standard to determine academic, not athletic standing of a particular student athlete (NCAA, 2001). For example, to be classified as a senior athlete by NCAA eligibility standards a student athlete must have completed $75 \%$ of their major degree requirements and only have one year of remaining competitive eligibility (NCAA, 2001).

\section{Methods}

Distribution of a questionnaire was the survey method for obtaining the information to answer the research questions. The instrument was distributed by the researcher to a contact in each of the athletic departments in the Mid-American Conference. The contacts handed out the 
questionnaires to a random sample of the selected members of the population at each school. Due to issues relating to The Family Education Right to Privacy Act ("The FERPA Answer Book," 2000), a cover letter was included with the instrument containing a guarantee of complete anonymity and that completion of the survey is voluntary. Questionnaires are regarded as an effective tool for measuring many different characteristics such as thoughts, feelings, attitudes, beliefs, values, and perceptions for research studies (Johnson \& Christensen, 2000).

\section{Sample}

The study used a proportional stratified sample of the population to complete the survey instrument. In proportional stratified sampling, the proportions in the sample on the stratification variable will be perfectly or almost perfectly representative of the proportions on that same stratification variable in the population (Johnson \& Christensen, 2000). The study examined 25\% of the selected population ( $\mathrm{n}=358$ ). For example, Eastern Michigan University represented 157 students in the total population, or $11 \%$. For the purposes of this study, using proportional stratified sampling, Eastern Michigan University received 39 surveys to distribute to selected student athletes. The selected student athletes received the survey through a contact in each institution's athletic department. Upon completion of the survey, each individual returned the instrument to the researcher via United States Post Office mail in a postage paid envelope. The most popular method of distributing questionnaires is by mail. Due to limited contact between the researcher and respondent, the response rate can often be very low and the public is often not willing to participate in surveys (Steeh, 1981). A response rate of 50\% plus one (at least $n=179$ ) for this study is considered an acceptable statistical sample of the population (Kerlinger, 1986). Fifty-four percent of the surveys were returned for a total of 191 respondents included in the analysis. 


\section{Design}

This study is a descriptive study. Much research in education is descriptive (Campbell \& Stanley, 1963; Kerlinger, 1986, Neumann, 1991). The purpose for this type of research is typically to learn about the specific details of a situation in social settings or relationships (Hinkle, Weirsma \& Jurs, 1998; Johnson \& Christensen, 2000; Neumann, 1991). The researcher collected data used for descriptive research. Descriptive research is defined as "research focused on providing an accurate description of picture of the status of characteristics of a situation or phenomenon" (Johnson \& Christensen, 2000, p. 302). Descriptive studies typically follow three steps, which are, random selection of a sample from a defined population, determining sample characteristics, and then inferring characteristics of the population based on the sample (Johnson \& Christensen, 2000). This study examined student athlete predictors and demographic data to confirm characteristics presented in the literature. The research question and predictors are analyzed using descriptive statistics (Johnson \& Christensen, 2000).

The study incorporated self-reported data that has been obtained from a proportional stratified sample of a population. The data were extracted from information provided on the survey instrument. No information provided compromised the anonymity of the participants in the survey. The survey method of collecting data is most often used in descriptive research (Johnson \& Christensen, 2000; Glatthorn, 1998).

This study utilized analytical statistical methodology to answer the theorized research questions and develop the variable relationship. The study gathered academic and non-academic information from student athletes at the 13 current Mid-American Conference institutions. The objective of this research was to determine whether and how many of the aforementioned predictors described in the literature can be generalized to student athletes in the Mid-American 
Conference. From the pattern of descriptive statistical relationships, inferences and potential explanations can be made to provide an accurate profile of a group or to give a verbal or numerical picture of a phenomenon (Neuman, 1991).

\section{Validity}

The nature of this study dictates the type and level of validity issues that require some level of justification. This research study attempts to overcome areas of concern relative to face validity and content validity in relation to predictors of graduation for NCAA Division I student athletes described in the literature.

Concerns relating to face validity in this study arise from the choice of the predictors of student athlete graduation. The student athlete predictors of graduation and descriptive data are clearly recognized in the literature as predictors of student athlete graduation. The literature indicates that these predictors also apply for populations of non-student athletes with regard to graduation from college (Adler \& Adler, 1985, 1991; Benson, 1991, 1994, 1997; Purdy, Eitzen, \& Hufnagel, 1982; Hoyt, 1968; Nicholson, 1973; Richards, Hollands, \& Lutz, 1966; Summers, 1991).

To minimize issues of content validity, the self-reported survey instrument was developed and inspired by an extensive review of past and present literature, surveys, and questionnaires, approved by a jury of experts, and trial tested through a pilot test of a like population. Of particular value to the development of the instrument were the American Institutes for Research Study of Intercollegiate Athletics (1981), The Reports of the Knight Commission on the Conduct of Intercollegiate Athletics (1991, 1993; “A Call to Action,” 2001), and NCAA Research Reports 91-04 (1991), 92-02 (1993), 96-02 (1997), 97-02 (1997), and 97-04 (1999). 
The survey instrument was presented to a jury of experts (Appendix C) for professional review and assessment. The jury of experts conducted a readability analysis and approved the questionnaire for use in the data collection. These individuals were in the best position to critique and assess the potential of the instrument due to their knowledge of the subject, knowledge of research methods, and experience in higher education administration.

The survey was trial tested through a pilot study with a like population to determine if any modifications need to be made. The survey was given to several Marshall University student athletes who will not be in the population selected for the study. The researcher selected twenty junior, by NCAA competitive eligibility standards, student athletes to complete the instrument. This group was chosen because of its similarities to the sample frame and it presents an acceptable cross section of ethnicity, gender, sport played, and academic profile. The purpose of the pilot study was to determine if the data gathered presented an accurate assessment of the answers (Johnson \& Christensen, 2000).

\section{Data Analysis}

The design of the study presented descriptive data analyzed using a widely used statistical computer program SPSS, version 10.1. The method of statistical analysis incorporates descriptive statistics to confirm if the characteristics of the literature can be generalized to student athletes in the Mid-American Conference. All data gathered from the questionnaire, along with the research question, were analyzed using descriptive statistics. The demographic information also serves to allow post-hoc analysis as deemed appropriate along with analysis of any potential ancillary findings. Demographic information examined in this study include gender, ethnicity, academic standing, expectation of graduation, college major, sport played in college, scholarship or nonscholarship, and score attained on SAT or ACT. 


\section{Summary}

The basis for this study was to determine if the predictors of graduation for NCAA

Division I student athletes described in the literature, which are perception of coaches' emphasis on academics, sport played in college, use of specialized academic services for student athletes, gender, ethnicity, core-course grade point average, and score attained on the SAT or ACT test, can be generalized to the Mid-American Conference based up research data. The study utilized data from the 2001-02 academic year reported by a selected random sample of a population of student athletes in the Mid-American Conference. Data was analyzed by descriptive statistics using SPSS, version 10.1. The results of this study may be generalized to other colleges and universities in NCAA Division I that admit a similar academic profile to their institution. 


\section{CHAPTER IV}

Presentation and Analysis of the Data

This chapter will present data collected on NCAA Division I student athletes in the MidAmerican Conference to ascertain if the students in the survey fit the profile of student athletes presented in the literature. In turn, the data in this study present research based conclusions to analyze if the findings in the literature and previous research can be generalized to the student athletes in the conference. The analysis of the data includes the development of descriptive statistics and examinations of the data to determine if the information provided by the selected population is representative of what is presented in the literature. The findings were interpreted to form conclusions in reference to the potential of graduation from college for selected NCAA Division I student athletes represented in the population. The analysis of the data is organized based on the specific research objectives of this study as outlined by the research question, predictors, and characteristics of graduation for NCAA Division I student athletes identified prominently in the literature. The purpose of this study is to ascertain if the predetermined characteristics of ethnicity, gender, high school core-course grade point average, ACT and/or SAT score, the sport played in college, student athletes' perceptions of coaches' emphasis on academics, and the use of specialized academic support services to determine if student athletes from the Mid-American Conference conform to the profile of the expected graduate as represented in the literature, allowing us to generalize from previous research.

The data were obtained via a self-reported survey instrument distributed to a random sample of Mid-American Conference student athletes who are currently in their last season of eligibility, or who have completed their allowed years of eligibility, of which almost all have not yet graduated from college. There are 12 graduate students represented in the survey who are still 
completing their final year of intercollegiate athletic eligibility. The data were analyzed using SPSS, version 10.1. The chapter includes the following sections: (a) demographic data, (b) major findings, (c) ancillary findings, and (d) a chapter summary.

\section{Demographic Data}

The data utilized in this study incorporate demographic information of 191 NCAA Division I student athletes enrolled at the 13 institutions of the Mid-American Conference who are in their final season of competitive eligibility, or who have finished competitive eligibility, but are still enrolled in college. In either case, all are within one academic year of graduation. The surveyed sample of $n=358$ was selected as a stratified proportional sample ( $25 \%)$ of the entire population of student athletes who met the population criteria at all of the current 13 schools of the Mid-American Conference ( $\mathrm{N}=1430)$. Fifty-four percent of the surveys were returned (191 total) representing males and females who compete in 27 sports.

A general analysis of the data presented offers several important insights. Several different statistical methods were utilized to analyze the data in order to establish if information provided in the literature can be generalized to the Mid-American Conference. An initial investigation of the data reveals the basic descriptive statistics of frequencies, means, standard deviations, and cross-tabulations. The statistical methods t-test and analysis of variance were used to gain even more specific knowledge on the impact a characteristic may have on the population and various subgroups within the population. A t-test was included on several analyses to determine if the differences between the means of the seven examined characteristics for this study are statistically significant (Johnson \& Christensen, 2000). The analyses of variance were included to measure the statistical difference between two or more of the 
characteristics and thereby providing a test of the significance, if any, of the characteristic on the surveyed population (Cohen \& Cohen, 1983).

\section{Major Findings}

The study is designed to answer the following research question regarding characteristics predictive of graduation described in the literature to determine if the results can be generalized to the Mid-American Conference:

Research Question:

Does the profile of the MAC athlete created from the information gleaned from the survey confirm the characteristics presented in the literature, thus allowing generalization of research based conclusions to Mid-American Conference athletes?

The following characteristics inspired by the literature are analyzed to describe the MidAmerican Conference athletes and to compare the survey sample to ascertain if the data from previous research and literature applies to the surveyed population:

1. Student athlete's perception of college coaches' emphasis on academics.

2. The extent of use of specialized academic support services for student athletes.

3. Specific sport played in college.

4. Ethnicity.

5. Gender.

6. High School Core-Course Grade Point Average.

7. Score attained on SAT or ACT test.

The characteristics of gender, ethnicity, and academic standing are represented by the student athlete respondents in the population (191 total). There are 90 female athletes and 101 male athletes who participated in the survey. Of that number there are 39 African Americans, 143 
Caucasians, and 9 from other ethnic backgrounds. The respondents in the survey are currently in their last season of competitive eligibility, but academic standing varies. Represented in the population are 26 juniors, 153 seniors, and 12 graduate students.

\section{Student Athlete's Perception of College Coach's Emphasis on Academics}

Student athlete's perception of college coach's emphasis on academics is ascertained primarily from survey questions 12-29 on the survey instrument. Questions 12-29 are separated into three distinct areas, and several other ancillary areas that a college coach can use to influence academic progress and potential of graduation for a student athlete in the Mid-American Conference. The three main areas of college coaches' emphasis on academics reflected on the survey instrument are during the recruiting process (Questions 12 and 13), during college enrollment (14-22), and during post eligibility years of enrollment, if applicable (23-24). The remaining six questions cover areas from time spent studying, time spent on athletic endeavors, controlling one's academic life, choice of school influenced by coach and feelings of the coach on academics and graduation. Certain questions are highlighted in the ensuing tables to show specific trends in the answers, in which the findings are discussed in depth in Chapter 5.

Specific answers by the respondents are analyzed in Tables 1,2, and 3. The answers are representative of all sports through frequency distributions that relate to college coaches emphasis on academics during the recruiting process and after college enrollment. The data in Tables 4 and 5 present the emphasis on academics versus athletics during the recruiting process by the coach, which is presented in questions 12 and 13 on the survey instrument. The data in Table 6 focus on coaches' emphasis on academics after college enrollment, representing question 14 on the survey instrument. 
Table 1

College Coaches’ Emphasis on Academics, All Sports.

Question 12 My coach emphasized academics more than athletics during the recruiting process.

\begin{tabular}{ccc}
\hline Answer & Frequency & Percentage \\
\hline Agree & 85 & 44.5 \\
Neutral & 82 & 42.9 \\
Disagree & 19 & 9.9 \\
Total & 186 & 97.4 \\
No & 5 & 2.6 \\
Answer & & 100.0 \\
Total & 191 & \\
\hline
\end{tabular}

Table 2

College Coaches Emphasis on Academics, All Sports.

Question 13 The coach made it clear to me about academics being more important than athletics during the recruiting process.

\begin{tabular}{ccc}
\hline Answer & Frequency & Percentage \\
\hline Agree & 115 & 60.2 \\
Neutral & 59 & 30.9 \\
Disagree & 11 & 5.8 \\
Total Reporting & 185 & 96.9 \\
No Answer & 6 & 3.1 \\
Total Sample & 191 & 100.0 \\
\hline
\end{tabular}


Table 3

College Coaches Emphasis on Academics, All Sports.

Question 14 After College Enrollment my coaches placed academic success above athletic success.

\begin{tabular}{ccc}
\hline Answer & Frequency & Percentage \\
\hline Agree & 88 & 46.1 \\
Neutral & 75 & 39.3 \\
Disagree & 28 & 14.7 \\
Total & 191 & 100.0 \\
\hline
\end{tabular}

The data presented in Tables 4 and 5 are concerned with college coaches' emphasis on academics in relation to if the coach prefers competitive eligibility rather than academic achievement or graduation. The data in these two tables are analyzed using frequency distributions derived from the answers given by respondents in all sports on the survey instrument. 
Table 4

College Coaches Emphasis on Academics, All Sports.

Question 22 My coach is more concerned with my graduation than my eligibility to play.

\begin{tabular}{ccc}
\hline Answer & Frequency & Percentage \\
\hline Agree & 59 & 30.9 \\
Neutral & 93 & 48.7 \\
Disagree & 39 & 20.4 \\
Total & 191 & 100.0 \\
\hline
\end{tabular}

Table 5

College Coaches Emphasis on Academics, All Sports.

Question 23 I believe my coach will be interested in my academic success when my eligibility expires.

\begin{tabular}{ccc}
\hline Answer & Frequency & Percentage \\
\hline Agree & 122 & 63.9 \\
Neutral & 41 & 21.5 \\
Disagree & 28 & 14.7 \\
Total & 191 & 100.0 \\
\hline
\end{tabular}

The Extent of Use of Academic Support Services for Student Athletes

Several questions on the survey instrument were used to ascertain the extent of use of academic support services for student athletes. The questions covered whether or not an individual student athlete felt they could graduate without having the ability to use these services. 
Question 43 asked if the respondent uses the academic support services on a regular basis (Table 6). In turn, Question 44 on the survey was a multi-part question where the respondent could indicate what services they use, or do not use. The choices for question 44 included advisement and registration, tutorial assistance, mentoring, computer lab, study hall, study skills, and learning disabled services. Advisement and registration, computer lab, and tutorial services made up the services most used by student athletes who responded to the survey. The answers were also indicative of those who stated they did not use the services on a regular basis, but who did indicate when they do use the services these are the same services they use. The data discussed on Tables 7 and 8 represent the number of student athletes who feel they must use these services to graduate and those who feel they do not need to use these services to graduate. The data for Tables 7 and 8 are drawn from questions 45 and 46 on the survey instrument. The questions are essentially the same, just posed in a different way. The breakdown of responses indicates that the response to each of these questions was relatively the same. 
Table 6

Extent of Use of Specialized Academic Support Services for Student Athletes.

Question 43 I Use Specialized Academic Support Services for Student Athletes on a Regular Basis.

\begin{tabular}{ccc}
\hline Answer & Frequency & Percentage \\
\hline Agree & 64 & 33.7 \\
Neutral & 45 & 23.7 \\
Disagree & 81 & 42.6 \\
Total Reporting & 190 & \\
Missing & 1 & \\
Total Sample & 191 & \\
\hline
\end{tabular}

Table 7

Extent of Use of Specialized Academic Support Services for Student Athletes.

Question 45 I Could Not Graduate Without Having Used These Services.

\begin{tabular}{ccc}
\hline Answer & Frequency & Percentage \\
\hline Agree & 50 & 26.2 \\
Neutral & 49 & 25.7 \\
Disagree & 91 & 47.6 \\
Total Reporting & 190 & 99.5 \\
Missing & 1 & \\
Total Sample & 191 & 100.0 \\
\hline
\end{tabular}


Table 8

Extent of Use of Specialized Academic Support Services for Student Athletes.

Question 46 I Do Not Need These Services to Graduate.

\begin{tabular}{ccc}
\hline Answer & Frequency & Percentage \\
\hline Agree & 78 & 40.8 \\
Neutral & 65 & 34.0 \\
Disagree & 48 & 25.1 \\
Total & 191 & 100.0 \\
\hline
\end{tabular}

Specific Sport Played in College

Questions relating to specific sport played are covered in questions 29-42 on the survey instrument. Several issues are encompassed within these specific questions, including the importance of academics, time spent studying, and if the specific sport competed in interferes with academic success. The frequency distribution of the completion of the survey instrument by sport is presented in Table 9. Twenty-seven sports are represented on the survey of which 14 are female sports and 13 are male sports. The student athletes on these teams represent numerous ethnic and academically diverse backgrounds.

Table 10 refers to selected sports showing the differences, through descriptive statistics, between revenue and non-revenue sports on the academic indicators of ACT/SAT score, NCAA core-course GPA, and current GPA. These four indicators are consistently cited in the literature as significant predictors of academic success in college and graduation from college for NCAA Division I student athletes (Benson, 1994, 1997). 
Five sports and the scores received in these four areas are compared in Table 10. Football and men's basketball are examined because these two sports are consistently the ones that score lower on these four predictors in NCAA Division I athletics (Benson, 1994, 1997). Women's basketball is included on Table 14 as a sport that traditionally due to gender, has superior performance in these four areas against male athletes in men's basketball and other male sports. However, that trend may be changing in NCAA Division I athletics as the sport becomes more popular and generates more revenue (J. Sutherland, personal communication, August 8, 2001; Schulman \& Bowen, 2001). The sports of synchronized skating and field hockey were included for comparison because they are typically non-revenue sports that are specific to females. 
Table 9

Frequency Statistics on Completion of Survey by Sport

\begin{tabular}{|c|c|c|}
\hline Sport & Frequency & Percentage \\
\hline Football & 48 & 25.1 \\
\hline Men's Basketball & 11 & 5.8 \\
\hline Women's Basketball & 6 & 3.1 \\
\hline Baseball & 16 & 8.4 \\
\hline Men's Volleyball & 3 & 1.6 \\
\hline Women's Volleyball & 12 & 6.3 \\
\hline $\begin{array}{l}\text { Track and Field M\&W } \\
\text { includes } \\
\text { Indoor /Outdoor/Cross } \\
\text { Country }\end{array}$ & 22 & 11.5 \\
\hline Men's Wrestling & 3 & 1.6 \\
\hline Tennis $(\mathrm{M} \& \mathrm{~W})$ & 6 & 3.1 \\
\hline $\begin{array}{l}\text { Swimming } \\
(\mathrm{M} \& \mathrm{~W})\end{array}$ & 15 & 7.9 \\
\hline Soccer (M\&W) & 15 & 7.9 \\
\hline Men's Ice Hockey & 4 & 2.1 \\
\hline
\end{tabular}


Table 9 (Continued)

Frequency Statistics on Completion of Survey by Sport.

\begin{tabular}{ccc}
\hline Sport & Frequency & Percentage \\
\hline $\begin{array}{c}\text { Women's } \\
\text { Field Hockey }\end{array}$ & 2 & 1.0 \\
Women's Softball & 15 & 7.6 \\
Women's Gymnastics & 6 & 3.1 \\
Golf & 2 & 1.0 \\
(M\&W) & 2 & 1.0 \\
Women's Lacrosse & & \\
Total & 191 & 100.0 \\
\hline
\end{tabular}


Table 10

Descriptive Statistics on Differences Between Selected Sports, Male and Female.

\begin{tabular}{|c|c|c|c|c|c|}
\hline Main Sport & & $\begin{array}{l}\text { ACT Test } \\
\text { Score }\end{array}$ & $\begin{array}{c}\text { SAT Test } \\
\text { Score }\end{array}$ & $\begin{array}{l}\text { Core-Course } \\
\text { GPA }\end{array}$ & $\begin{array}{c}\text { Current College } \\
\text { GPA }\end{array}$ \\
\hline \multirow[t]{3}{*}{ Football } & Mean & 20.87 & 1022.11 & 3.016 & 2.809 \\
\hline & $\mathrm{N}$ & 31 & 19 & 44 & 47 \\
\hline & $\begin{array}{c}\text { Std. } \\
\text { Deviation }\end{array}$ & 3.085 & 112.821 & .5570 & .4973 \\
\hline \multirow[t]{3}{*}{ Men's Basketball } & Mean & 21.33 & 1140.00 & 3.230 & 2.936 \\
\hline & $\mathrm{N}$ & 6 & 1 & 10 & 11 \\
\hline & $\begin{array}{c}\text { Std. } \\
\text { Deviation }\end{array}$ & 4.367 & . & .5982 & .6313 \\
\hline \multirow{3}{*}{$\begin{array}{l}\text { Women's } \\
\text { Basketball }\end{array}$} & Mean & 21.67 & 990.00 & 3.100 & 2.883 \\
\hline & $\mathrm{N}$ & 3 & 1 & 6 & 6 \\
\hline & $\begin{array}{c}\text { Std. } \\
\text { Deviation }\end{array}$ & 2.309 & . & .4382 & .4401 \\
\hline \multirow{3}{*}{$\begin{array}{l}\text { Synchronized } \\
\text { Skating }\end{array}$} & Mean & 26.00 & 1220.00 & 3.650 & 3.067 \\
\hline & $\mathrm{N}$ & 3 & 1 & 2 & 3 \\
\hline & $\begin{array}{c}\text { Std. } \\
\text { Deviation }\end{array}$ & 2.646 & . & .2121 & .1155 \\
\hline \multirow[t]{3}{*}{ Field Hockey } & Mean & 28.00 & 1230.00 & 3.500 & 3.250 \\
\hline & $\mathrm{N}$ & 1 & 2 & 2 & 2 \\
\hline & $\begin{array}{c}\text { Std. } \\
\text { Deviation }\end{array}$ & . & 42.426 & .4243 & .4950 \\
\hline
\end{tabular}




\section{Ethnicity}

The ethnic background of the student athletes who responded to the survey is represented in question 2 on the survey instrument, "What is your ethnicity?" All 191 respondents answered this question. The respondents had five choices to select from to include African American, Asian Pacific Islander, Caucasian, Hispanic, and Other. A high percentage of the respondents were Caucasian and the second highest group that responded was African Americans. This response rate correlates with the ethnic percentage of all students at the institutions of the Mid-American Conference (C. Peacock, personal communication, February 12, 2002). Only nine of the respondents to the survey were of any other ethnic background. The data in Table 3 present the frequency distribution of the completion of the survey instrument by ethnicity.

Table 11

Frequency Statistics on Completion of Survey by Ethnicity.

\begin{tabular}{ccc}
\hline Ethnicity & Frequency & Percentage \\
\hline African-American & 39 & 20.4 \\
Asian/ \\
Pacific Islander & 1 & .5 \\
Caucasian & 143 & \\
Hispanic & 3 & 74.9 \\
Other & 5 & 1.6 \\
Total & 191 & 2.6 \\
\hline
\end{tabular}




\section{Gender}

The question of gender was the first item on the survey instrument. All 191 respondents answered this particular question. The breakdown between males and females was almost split evenly. Of the 191 total respondents, 90 were female and 101 were male. There are more male student athletes in the Mid-American Conference due to the large numbers of football players at each institution. Females do not have a comparable sport with comparable numbers, so the breakdown by gender for this study is a near accurate representation of the gender percentages for all student athletes at institutions of the Mid-American Conference. The data in Table 2 present the frequency distribution of males and females who responded to the survey. Table 12

Frequency Statistics on Completion of Survey by Gender.

\begin{tabular}{ccc}
\hline Gender & Frequency & Percentage \\
\hline Female & 90 & 47.1 \\
Male & 101 & 52.9 \\
Total & 191 & 100.0 \\
\hline
\end{tabular}

NCAA Core-Course Grade Point Average

The NCAA core-course grade point average is different from an overall high school Grade Point Average in that it measures only the GPA in 13 college preparatory classes (NCAA, 2001). NCAA core-course grade point average is reflected on the survey instrument in question number 10. One hundred sixty-five of the respondents answered this question. The answer, if given, was based upon recollection of the respondent as to their core-course GPA. This contributed to many 
of the members of the surveyed sample not being able to remember the answer. Many responded either “don't know," or “I can’t remember."

The researcher, using descriptive statistics, analyzed core-course grade point average and established a frequency distribution of all core-course grade point averages reported by the population. There is a broad spectrum of NCAA core-course grade point averages reported by the respondents. A higher percentage of student athletes who answered the question reported corecourse GPAs of 2.5 or higher. A 2.5 GPA is the minimum core-course GPA needed, with a corresponding entrance exam score, to be initially eligible in intercollegiate athletics (NCAA, 2001). The majority of the student athletes who responded reported core-course GPAs at 3.0 and higher. Table 21 represents all sports, gender, and ethnic backgrounds reporting core-course grade point averages of 1.7 through 4.0. 
Table 13

Core-Course GPA Reported by All Sports.

\begin{tabular}{|c|c|c|}
\hline GPA & Frequency & Percentage \\
\hline 1.7 & 1 & .5 \\
\hline 1.9 & 1 & .5 \\
\hline 2.0 & 2 & 1.0 \\
\hline 2.2 & 2 & 1.0 \\
\hline 2.3 & 3 & 1.6 \\
\hline 2.4 & 1 & .5 \\
\hline 2.5 & 9 & 4.7 \\
\hline 2.6 & 2 & 1.0 \\
\hline 2.7 & 7 & 3.7 \\
\hline 2.8 & 12 & 6.3 \\
\hline 2.9 & 7 & 3.7 \\
\hline 3.0 & 9 & 4.7 \\
\hline 3.1 & 3 & 1.6 \\
\hline 3.2 & 13 & 6.8 \\
\hline 3.3 & 14 & 7.3 \\
\hline 3.4 & 7 & 3.7 \\
\hline 3.5 & 13 & 6.8 \\
\hline 3.6 & 11 & 5.8 \\
\hline 3.7 & 9 & 4.7 \\
\hline 3.8 & 14 & 7.3 \\
\hline 3.9 & 8 & 4.2 \\
\hline 4.0 & 17 & 8.9 \\
\hline Total Reporting & 165 & 86.4 \\
\hline Missing & 26 & 13.6 \\
\hline Total Sample & 191 & 100.0 \\
\hline
\end{tabular}




\section{ACT/SAT Test Score}

The answer to score attained on the ACT or SAT is reflected on the survey instrument on question 9. Like the information provided on NCAA core-course grade point average, this specific answer was also based on the recollection of the respondent. Table 14 represents a frequency distribution of all of the respondents who answered the question of "What was your entrance exam score (One or both)?" on question 9 on the survey instrument. With regards to the ACT score, 99 student athletes responded out of the 143 total who answered the question. The score distribution ranges from a composite score of 18 to the highest reported score of 31 . Sixtythree of the 143 respondents who answered question 9 took the SAT. There were 19 respondents who reported scores from both tests on the survey instrument. The scoring range on the SAT is very broad, indicative of the type of scoring system used for the SAT. The scores reported for the SAT range from 820 to 1420 . 
Table 14

ACT Test Score. Frequency Distribution, All Sports.

\begin{tabular}{|c|c|c|}
\hline Score & Frequency & Percentage \\
\hline 18 & 7 & 4.9 \\
\hline 19 & 9 & 6.3 \\
\hline 20 & 2 & 1.4 \\
\hline 21 & 17 & 11.9 \\
\hline 22 & 7 & 4.9 \\
\hline 23 & 13 & 9.1 \\
\hline 24 & 12 & 8.4 \\
\hline 25 & 10 & 7.0 \\
\hline 26 & 6 & 4.2 \\
\hline 27 & 4 & 2.8 \\
\hline 28 & 5 & 3.5 \\
\hline 29 & 4 & 2.8 \\
\hline 30 & 2 & 1.4 \\
\hline 31 & 1 & .7 \\
\hline Total Reporting & 99 & 69.2 \\
\hline
\end{tabular}


Table 15

SAT Test Score. Frequency Distribution, All Sports.

\begin{tabular}{|c|c|c|}
\hline Score & Frequency & Percentage \\
\hline 820 & 1 & .7 \\
\hline 860 & 1 & .7 \\
\hline 875 & 1 & .7 \\
\hline 880 & 1 & .7 \\
\hline 920 & 1 & .7 \\
\hline 960 & 2 & 1.4 \\
\hline 970 & 2 & 1.4 \\
\hline 980 & 2 & 1.4 \\
\hline 990 & 2 & 1.4 \\
\hline 1000 & 1 & .7 \\
\hline 1010 & 3 & 2.1 \\
\hline 1020 & 3 & 2.1 \\
\hline 1030 & 1 & .7 \\
\hline 1040 & 3 & 2.1 \\
\hline 1050 & 4 & 2.8 \\
\hline 1080 & 5 & 3.5 \\
\hline 1090 & 2 & 1.4 \\
\hline 1100 & 4 & 2.8 \\
\hline 1120 & 3 & 2.1 \\
\hline 1130 & 1 & .7 \\
\hline
\end{tabular}


Table 15 (Continued)

SAT Test Score. Frequency Distribution, All Sports.

\begin{tabular}{ccc}
\hline Score & Frequency & Percentage \\
\hline 1140 & 1 & .7 \\
1150 & 2 & 1.4 \\
1160 & 1 & .7 \\
1200 & 3 & 2.1 \\
1210 & 2 & 1.4 \\
1220 & 2 & 1.4 \\
1230 & 1 & .7 \\
1240 & 1 & .7 \\
1260 & 2 & 1.4 \\
1270 & 1 & .7 \\
1280 & 2 & 1.4 \\
1330 & 1 & .7 \\
1420 & 1 & .7 \\
Total Reporting & 63 & 44.1 \\
\hline
\end{tabular}

Ancillary Findings

This study is a descriptive study of which the purpose is to determine if data from the literature can be generalized to student athletes of the Mid-American Conference based on conclusions from the study. Those conclusions have been mostly derived from simple data analysis that ascertains the frequencies of certain responses to the research question and the 
seven characteristics. A more in depth analysis of the seven characteristics combined in some way with one another yields some very interesting ancillary findings and strengthens the purpose of this study by presenting more data that can be used to answer the research question above the previous descriptive tables.

The first ancillary finding was derived from an Analysis of Variance to determine if there was a significant difference between groups represented on the survey concerning student athlete's perception of college coaches' emphasis on academics. Table 16 is a one-way analysis of variance on all groups who responded to questions 12-29 on the instrument to see if there is a significant difference between the answers of the different groups represented in the surveyed population. The significance for the analysis on Table 9 was tested at a $p<.05$ level. The analysis shows that there is no significant difference in the responses between all groups represented on the survey instrument.

Table 16

Analysis of Variance, All Sports.

College Coaches Emphasis on Academics (Questions 12-29)

\begin{tabular}{cccccc}
\hline & $\begin{array}{c}\text { Sum of } \\
\text { Squares }\end{array}$ & df & Mean Square & F & Sig. \\
\hline $\begin{array}{c}\text { Between } \\
\text { Groups }\end{array}$ & 198.717 & 16 & 12.420 & .860 & .616 \\
Within & 2382.932 & 165 & 14.442 & & \\
Groups & & & & & \\
$\quad$ Total & 2581.648 & 181 & & & \\
\hline $\mathrm{p}<.05$ & & & & &
\end{tabular}

The data presented in Tables 17 and 18 analyze questions 45 and 46 on the survey instrument. These two questions concern the extent of use of specialized academic support 
services for student athletes. The questions are analyzed through a cross tabulation by ethnicity to see if there is a difference between ethnic groups on the use of these types of services, specifically if members of a certain ethnic group feel that they must use these services in order to graduate. The questions were designed to ask the same thing but in a different way. Question 45 asked if the respondents felt they could not graduate without these services while question 46 asked if the respondents needed these services to graduate. The data presented in Tables 19 and 20 analyze the same questions, but using gender and the extent of use of specialized academic support services for student athletes in a cross tabulation analysis. 
Table 17

Cross-Tabulation Use of Academic Services by Ethnicity, All Sports.

Question 45. I could not graduate without use of these services.

\begin{tabular}{ccccccc}
\hline \multicolumn{2}{c}{ Ethnicity } & \multicolumn{2}{c}{ Total } \\
\hline Answer & $\begin{array}{c}\text { African- } \\
\text { American } \\
\text { (Black) }\end{array}$ & $\begin{array}{c}\text { Asian/Pacific } \\
\text { Islander }\end{array}$ & $\begin{array}{c}\text { Caucasian } \\
\text { (White) }\end{array}$ & Hispanic & Other & \\
\hline Agree & 19 & 1 & 27 & 1 & 2 & 50 \\
Neutral & 12 & & 37 & & 3 & 49 \\
Disagree & 7 & 1 & 143 & 3 & 5 & 190 \\
Total & 38 & & & 2 & 3 & \\
\hline
\end{tabular}

Table 18

Cross-Tabulation by Ethnicity, All Sports.

Question 46. I do not need these services to graduate.

\begin{tabular}{ccccccc}
\hline \multicolumn{2}{c}{ Ethnicity } & & & Total \\
\hline Answer & $\begin{array}{c}\text { African- Asian/Pacific } \\
\text { American } \\
\text { (Black) }\end{array}$ & Islander & $\begin{array}{c}\text { Caucasian } \\
\text { (White) }\end{array}$ & Hispanic & Other & \\
\hline Agree & 7 & 67 & 2 & 2 & 78 \\
Neutral & 11 & 52 & & 2 & 65 \\
Disagree & 21 & 1 & 24 & 1 & 1 & 48 \\
Total & 39 & 1 & 143 & 3 & 5 & 191 \\
\hline
\end{tabular}


Table 19

Cross-Tabulation by Gender, All Sports.

Question 45. I could not graduate without having used these services.

\begin{tabular}{ccccc}
\hline Answer & & Gender & & Total \\
\hline Agree & Count & Female & Male & \\
& \% of Total & $10.0 \%$ & $16.3 \%$ & $26.3 \%$ \\
Neutral & Count & 24 & 25 & 49 \\
& \% of Total & $12.6 \%$ & $13.2 \%$ & $25.8 \%$ \\
Disagree & Count & 47 & 44 & 91 \\
& \% of Total & $24.7 \%$ & $23.2 \%$ & $47.9 \%$ \\
Total & Count & 90 & 100 & 190 \\
& \% of Total & $47.4 \%$ & $52.6 \%$ & $100.0 \%$ \\
\hline
\end{tabular}


Table 20

Cross-Tabulation by Gender, All Sports.

Question 46. I do not need these services to graduate.

\begin{tabular}{ccccc}
\hline Answer & & Gender & & Total \\
\hline Agree & Count & 41 & 37 & 78 \\
& \% of Total & $21.5 \%$ & $19.4 \%$ & $40.8 \%$ \\
Neutral & Count & 29 & 36 & 65 \\
& \% of Total & $15.2 \%$ & $18.8 \%$ & $34.0 \%$ \\
Disagree & Count & 20 & 28 & 48 \\
& \% of Total & $10.5 \%$ & $14.7 \%$ & $25.1 \%$ \\
Total & Count & 90 & 101 & 191 \\
& \% of Total & $47.1 \%$ & $52.9 \%$ & $100.0 \%$ \\
\hline
\end{tabular}

Some of the most significant ancillary findings were analyses of the two primary revenue sports of men's basketball and football by ethnicity and the academic constructs of SAT/ACT score, NCAA core-course grade point average, and current college grade point average. Current college grade point average was not one of the seven characteristics analyzed for this study, but the respondents were asked on question number 11 to give their current GPA. Using current GPA data in the types of analyses presented in Tables 21 and 22 is an attempt to strengthen the findings of the researcher by confirming or not confirming if what is presented in the literature. The data presented in Tables 21 and 22 uses specific sport participated in as the basis for the analysis. Again, the sports of men's basketball and football are analyzed by ethnicity due to the perceived significance of lower academic achievement on the four aforementioned academic areas in those 
sports, according to the literature. The data presented in Tables 21 and 22 show Caucasians in the sports of men's basketball and football have higher achievement in the four measured academic areas.

A test for significance between African-Americans and Caucasians in all sports on the four academic areas was performed through a one-way analysis of variance as represented on Table 23. With ethnicity as the base measurement for the four academic areas, the data presented in Table 23 show a significant difference between all ethnic groups in each of the four areas. The data on Table 23 reinforce the frequency data presented in Tables 21 and 22. The significance between the groups in ACT score, Core-Course GPA, and Current College GPA was tested at a $\mathrm{p}<.05$ level of significance and the SAT score was tested at a $\mathrm{p}<.01$ level of significance. Since the population is primarily composed of Caucasians and African Americans there are many inferences that can be made from the data on this particular table. 
Table 21

Group Statistics Men's Basketball Based on Ethnicity.

\begin{tabular}{|c|c|c|c|c|c|}
\hline & Ethnicity & $\mathrm{N}$ & Mean & Std. Deviation & Std. Error Mean \\
\hline \multirow[t]{2}{*}{$\begin{array}{c}\text { ACT test } \\
\text { score }\end{array}$} & $\begin{array}{l}\text { African- } \\
\text { American } \\
\text { (Black) }\end{array}$ & 2 & 19.00 & 1.414 & 1.000 \\
\hline & $\begin{array}{c}\text { Caucasian } \\
\text { (White) }\end{array}$ & 3 & 24.67 & 3.215 & 1.856 \\
\hline \multirow[t]{2}{*}{$\begin{array}{l}\text { Core- } \\
\text { course } \\
\text { GPA }\end{array}$} & $\begin{array}{l}\text { African- } \\
\text { American } \\
\text { (Black) }\end{array}$ & 5 & 2.920 & .5215 & .2332 \\
\hline & $\begin{array}{c}\text { Caucasian } \\
\text { (White) }\end{array}$ & 4 & 3.600 & .6055 & .3028 \\
\hline \multirow[t]{2}{*}{$\begin{array}{c}\text { Current } \\
\text { college } \\
\text { GPA }\end{array}$} & $\begin{array}{l}\text { African- } \\
\text { American } \\
\text { (Black) }\end{array}$ & 6 & 2.767 & .5391 & .2201 \\
\hline & $\begin{array}{c}\text { Caucasian } \\
\text { (White) }\end{array}$ & 4 & 3.275 & .7719 & .3860 \\
\hline $\begin{array}{c}\text { SAT test } \\
\text { score }\end{array}$ & $\begin{array}{l}\text { African- } \\
\text { American } \\
\text { (Black) }\end{array}$ & 1 & 1140.00 & . & . \\
\hline
\end{tabular}


Table 22

Group Statistics of Football Based on Ethnicity.

\begin{tabular}{|c|c|c|c|c|c|}
\hline & Ethnicity & $\mathrm{N}$ & Mean & Std. Deviation & Std. Error Mean \\
\hline \multirow[t]{2}{*}{$\begin{array}{c}\text { ACT Test } \\
\text { Score }\end{array}$} & $\begin{array}{l}\text { African- } \\
\text { American } \\
\text { (Black) }\end{array}$ & 14 & 19.00 & 1.617 & 32 \\
\hline & $\begin{array}{c}\text { Caucasian } \\
\text { (White) }\end{array}$ & 17 & 22.41 & 3.183 & .772 \\
\hline \multirow[t]{2}{*}{$\begin{array}{c}\text { SAT Test } \\
\text { Score }\end{array}$} & $\begin{array}{l}\text { African- } \\
\text { American } \\
\text { (Black) }\end{array}$ & 6 & 940.00 & 107.145 & 43.742 \\
\hline & $\begin{array}{c}\text { Caucasian } \\
\text { (White) }\end{array}$ & 13 & 1060.00 & 96.868 & 26.866 \\
\hline \multirow[t]{2}{*}{$\begin{array}{l}\text { Core- } \\
\text { Course } \\
\text { GPA }\end{array}$} & $\begin{array}{l}\text { African- } \\
\text { American } \\
\text { (Black) }\end{array}$ & 19 & 2.600 & .4460 & .1023 \\
\hline & $\begin{array}{c}\text { Caucasian } \\
\text { (White) }\end{array}$ & 25 & 3.332 & .4069 & .0814 \\
\hline \multirow[t]{2}{*}{$\begin{array}{c}\text { Current } \\
\text { College } \\
\text { GPA }\end{array}$} & $\begin{array}{l}\text { African- } \\
\text { American } \\
\text { (Black) }\end{array}$ & 22 & 2.468 & .2818 & .0601 \\
\hline & $\begin{array}{c}\text { Caucasian } \\
\text { (White) }\end{array}$ & 25 & 3.108 & .4527 & .0905 \\
\hline
\end{tabular}


Table 23

One Way Analysis of Variance. Ethnicity Difference Between Groups.

\begin{tabular}{|c|c|c|c|c|c|c|}
\hline & & Sum of Squares & $\mathrm{df}$ & Mean Square & $\mathrm{F}$ & Significance \\
\hline \multirow[t]{3}{*}{$\begin{array}{l}\text { ACT Test } \\
\text { Score }\end{array}$} & $\begin{array}{c}\text { Between } \\
\text { Groups }\end{array}$ & 223.430 & 3 & 74.477 & 7.827 & $.000^{* *}$ \\
\hline & $\begin{array}{l}\text { Within } \\
\text { Groups }\end{array}$ & 1122.775 & 118 & 9.515 & & \\
\hline & Total & 1346.205 & 121 & & & \\
\hline \multirow[t]{3}{*}{$\begin{array}{l}\text { SAT Test } \\
\text { Score }\end{array}$} & $\begin{array}{c}\text { Between } \\
\text { Groups }\end{array}$ & 170396.960 & 3 & 56798.987 & 4.093 & $.010 *$ \\
\hline & $\begin{array}{l}\text { Within } \\
\text { Groups }\end{array}$ & 999225.079 & 72 & 13878.126 & & \\
\hline & Total & 1169622.039 & 75 & & & \\
\hline \multirow{3}{*}{$\begin{array}{l}\text { Core- } \\
\text { Course } \\
\text { GPA }\end{array}$} & $\begin{array}{c}\text { Between } \\
\text { Groups }\end{array}$ & 10.198 & 4 & 2.549 & 11.329 & $.000 * *$ \\
\hline & $\begin{array}{l}\text { Within } \\
\text { Groups }\end{array}$ & 36.005 & 160 & .225 & & \\
\hline & Total & 46.203 & 164 & & & \\
\hline \multirow{3}{*}{$\begin{array}{c}\text { Current } \\
\text { College } \\
\text { GPA }\end{array}$} & $\begin{array}{c}\text { Between } \\
\text { Groups }\end{array}$ & 13.668 & 4 & 3.417 & 17.017 & $.000 * *$ \\
\hline & $\begin{array}{l}\text { Within } \\
\text { Groups }\end{array}$ & 36.946 & 184 & .201 & & \\
\hline & Total & 50.614 & 188 & & & \\
\hline
\end{tabular}


As with many of the previous characteristics, ancillary data concerning gender of the respondents are analyzed by ethnicity, sport played, and performance on the four indicators of academic achievement for student athletes used in this study. Table 24 represents all respondents and all sports. The analysis reflects performance by gender in these areas. Table 25 represents the same analysis reflecting ethnicity and gender specifically in the sports of men's and women's basketball and football. Comparisons of the same groups analyzed in Table 24 were analyzed through a one-way analysis of variance in Table 25 to determine if there was a statistically significant difference in the four indicators of academic achievement for a student athlete used for this study. The significance for this analysis of variance was tested at $\mathrm{p}<.01$ level.

The data in Table 24 show females having higher achievement in the four areas, but the data in Table 25 show women's basketball players having lower levels of achievement in three of the four areas, excluding current college GPA when compared with Caucasian males in the sports of football and men's basketball. The data from the analysis of variance in Table 26 present a significant difference between females and males on three of the four areas, excluding the SAT score. 
Table 24

T-Test Comparisons Based on Gender.

\begin{tabular}{|c|c|c|c|c|c|}
\hline & Gender & $\mathrm{N}$ & Mean & Std. Deviation & Std. Error Mean \\
\hline \multirow{2}{*}{$\begin{array}{c}\text { ACT Test } \\
\text { Score }\end{array}$} & Male & 61 & 21.70 & 3.432 & .439 \\
\hline & Female & 61 & 23.39 & 3.035 & .389 \\
\hline \multirow{2}{*}{$\begin{array}{l}\text { SAT test } \\
\text { Score }\end{array}$} & Male & 39 & 1037.82 & 120.202 & 19.248 \\
\hline & Female & 37 & 1103.51 & 122.321 & 20.109 \\
\hline \multirow{2}{*}{$\begin{array}{l}\text { Core- } \\
\text { Course } \\
\text { GPA }\end{array}$} & Male & 89 & 3.112 & .5340 & .0566 \\
\hline & Female & 76 & 3.467 & .4611 & .0529 \\
\hline \multirow{2}{*}{$\begin{array}{c}\text { Current } \\
\text { College } \\
\text { GPA }\end{array}$} & Male & 100 & 2.842 & .4863 & .0486 \\
\hline & Female & 89 & 3.264 & .4628 & .0491 \\
\hline
\end{tabular}


Table 25

Descriptive Data on Gender and Ethnicity Football, Men's and Women's Basketball.

\begin{tabular}{|c|c|c|c|c|c|}
\hline $\begin{array}{c}\text { Gender and } \\
\text { Ethnicity } \\
\end{array}$ & & $\begin{array}{c}\text { ACT Test } \\
\text { Score } \\
\end{array}$ & $\begin{array}{c}\text { SAT Test } \\
\text { Score }\end{array}$ & Core-course GPA & Current college GPA \\
\hline \multirow{3}{*}{$\begin{array}{c}\text { Caucasian } \\
\text { Females }\end{array}$} & Mean & 22.50 & 990.00 & 3.283 & 3.267 \\
\hline & $\mathrm{N}$ & 4 & 1 & 6 & 6 \\
\hline & $\begin{array}{c}\text { Std. } \\
\text { Deviation }\end{array}$ & 3.416 & . & .5154 & .5164 \\
\hline \multirow{3}{*}{$\begin{array}{l}\text { Caucasian } \\
\text { Males }\end{array}$} & Mean & 22.61 & 1060.00 & 3.330 & 3.081 \\
\hline & $\mathrm{N}$ & 18 & 13 & 27 & 27 \\
\hline & $\begin{array}{c}\text { Std. } \\
\text { Deviation }\end{array}$ & 3.202 & 96.868 & .4250 & .4707 \\
\hline \multirow{3}{*}{$\begin{array}{l}\text { African } \\
\text { American } \\
\text { Females }\end{array}$} & Mean & 23.00 & & 3.900 & 3.100 \\
\hline & $\mathrm{N}$ & 1 & & 1 & 1 \\
\hline & $\begin{array}{c}\text { Std. } \\
\text { Deviation }\end{array}$ & . & & . & . \\
\hline \multirow{3}{*}{$\begin{array}{l}\text { African } \\
\text { American } \\
\text { Males }\end{array}$} & Mean & 19.00 & 968.57 & 2.672 & 2.521 \\
\hline & $\mathrm{N}$ & 16 & 7 & 25 & 29 \\
\hline & $\begin{array}{c}\text { Std. } \\
\text { Deviation }\end{array}$ & 1.549 & 123.616 & .4605 & .3609 \\
\hline \multirow[t]{3}{*}{ Total } & Mean & 21.13 & 1026.19 & 3.056 & 2.841 \\
\hline & $\mathrm{N}$ & 39 & 21 & 59 & 63 \\
\hline & $\begin{array}{c}\text { Std. } \\
\text { Deviation }\end{array}$ & 3.113 & 110.385 & .5547 & .5148 \\
\hline
\end{tabular}


Table 26

One Way Analysis of Variance Based on Gender, Ethnicity, and Sport Played. All Sports.

\begin{tabular}{|c|c|c|c|c|c|c|}
\hline & & $\begin{array}{l}\text { Sum of } \\
\text { Squares }\end{array}$ & $\mathrm{df}$ & $\begin{array}{l}\text { Mean } \\
\text { Square }\end{array}$ & $\mathrm{F}$ & Sig. \\
\hline \multirow[t]{3}{*}{$\begin{array}{l}\text { ACT Test } \\
\text { Score }\end{array}$} & $\begin{array}{c}\text { Between } \\
\text { Groups }\end{array}$ & 123.081 & 3 & 41.027 & 5.854 & $.002 * *$ \\
\hline & $\begin{array}{l}\text { Within } \\
\text { Groups }\end{array}$ & 245.278 & 35 & 7.008 & & \\
\hline & Total & 368.359 & 38 & & & \\
\hline \multirow[t]{3}{*}{$\begin{array}{l}\text { SAT Test } \\
\text { Score }\end{array}$} & $\begin{array}{c}\text { Between } \\
\text { Groups }\end{array}$ & 39409.524 & 2 & 19704.762 & 1.736 & .204 \\
\hline & $\begin{array}{l}\text { Within } \\
\text { Groups }\end{array}$ & 204285.714 & 18 & 11349.206 & & \\
\hline & Total & 243695.238 & 20 & & & \\
\hline \multirow{3}{*}{$\begin{array}{c}\text { Core- } \\
\text { Course } \\
\text { GPA }\end{array}$} & $\begin{array}{c}\text { Between } \\
\text { Groups }\end{array}$ & 6.730 & 3 & 2.243 & 11.101 & $.000 * *$ \\
\hline & $\begin{array}{l}\text { Within } \\
\text { Groups }\end{array}$ & 11.115 & 55 & .202 & & \\
\hline & Total & 17.845 & 58 & & & \\
\hline \multirow{3}{*}{$\begin{array}{c}\text { Current } \\
\text { College } \\
\text { GPA }\end{array}$} & $\begin{array}{c}\text { Between } \\
\text { Groups }\end{array}$ & 5.691 & 3 & 1.897 & 10.420 & $.000 * *$ \\
\hline & $\begin{array}{l}\text { Within } \\
\text { Groups }\end{array}$ & 10.742 & 59 & .182 & & \\
\hline & Total & 16.433 & 62 & & & \\
\hline
\end{tabular}


The answer to what was the score attained on an entrance exam is presented in question 9 on the survey instrument. The score identified, if answered by the respondent, was based upon recollection of the individual. Table 27 represents data from an analysis of variance, testing significance of difference on score attained on the ACT or SAT, between groups represented on the survey by gender, ethnicity, and sport played. The level of significance for this analysis was done at $\mathrm{p}<.01$. The data presented in Table 27 show a significant difference on the ACT score when factoring in gender, ethnicity, and specific sport played using all sports represented on the survey.

Table 27

Analysis of Variance Based on Gender, Ethnicity, and Sport Played Relating to ACT/SAT Test Score

\begin{tabular}{|c|c|c|c|c|c|c|}
\hline & & $\begin{array}{l}\text { Sum of } \\
\text { Squares }\end{array}$ & $\mathrm{df}$ & Mean Square & $\mathrm{F}$ & Sig. \\
\hline \multirow[t]{3}{*}{$\begin{array}{l}\text { ACT Test } \\
\text { Score }\end{array}$} & $\begin{array}{l}\text { Between } \\
\text { Groups }\end{array}$ & 123.081 & 3 & 41.027 & 5.854 & $.002 * *$ \\
\hline & $\begin{array}{l}\text { Within } \\
\text { Groups }\end{array}$ & 245.278 & 35 & 7.008 & & \\
\hline & Total & 368.359 & 38 & & & \\
\hline \multirow[t]{3}{*}{$\begin{array}{l}\text { SAT Test } \\
\text { Score }\end{array}$} & $\begin{array}{l}\text { Between } \\
\text { Groups }\end{array}$ & 39409.524 & 2 & 19704.762 & 1.736 & .204 \\
\hline & $\begin{array}{l}\text { Within } \\
\text { Groups }\end{array}$ & 204285.714 & 18 & 11349.206 & & \\
\hline & Total & 243695.238 & 20 & & & \\
\hline
\end{tabular}




\section{Summary}

From an overall perspective, the value of this study lies in the ability to generalize many facets of the literature and form research based conclusions to NCAA Division I student athletes in the Mid-American Conference. Several characteristics that the literature state as significant predictors of graduation were analyzed to determine if the data and literature reached similar conclusions thus allowing generalization to student athletes in the Mid-American Conference. The specific characteristics, or predictors, analyzed were college coaches emphasis on academics, the extent of use of academic support services for student athletes, sport played in college, gender, ethnicity, score attained on the SAT/ACT test, and core-course grade point average. The study included 191 surveys returned from a randomly selected stratified proportional sample of 358 answered by student athletes in the Mid-American Conference representing 27 men's and women's sports.

Major findings included descriptive data on how many total responded to the survey. The total number of respondents was further broken down by gender, ethnicity, and specific sport played in college. Other descriptive data and frequencies were performed on the other characteristics of extent of use of specialized academic support services for student athletes, NCAA core-course grade point average, and score attained on the SAT and/or ACT. Several ancillary findings were discussed and analyses performed on many of the characteristics in combination with one another or cross-tabulated with several of the characteristics included. 


\section{CHAPTER V}

Summary of Study, Conclusions, and Recommendations

This chapter states the purpose of this study, a summary of the procedures involved in the study, and a summary of the demographic data that were analyzed. The findings of the analysis were interpreted to form conclusions about the characteristics and predictors of graduation of NCAA student athletes described in this research. A summary of the findings and conclusions are presented in reference to the research question and characteristics of student athlete graduation. The chapter also includes implications for the study relative to higher education administration and recommendations for future research in the area of NCAA Division I student athlete academic progress and graduation rates.

\section{Purpose of the Study}

The purpose of this study is to determine if the predictors of ethnicity, gender, high school core-course grade point average, ACT and/or SAT score, the specific sport played in college, student athlete's perception of coaches emphasis on academics, and the use of specialized academic support services for student athletes as described in the literature, can be generalized to NCAA Division I student athletes in the Mid-American Conference. The following research question, characteristics, and student demographics provided a basis for the study:

\section{Research Question:}

Does the profile of the MAC athlete created from the information gleaned from the survey confirm the characteristics presented in the literature, thus allowing generalization of research based conclusions to Mid-American Conference athletes? 
The following characteristics inspired by the literature are analyzed to describe the MidAmerican Conference athletes and to compare the survey sample to the groups represented in the literature:

1. Student athlete's perception of college coaches emphasis on academics.

2. The extent of use of specialized academic support services for student athletes.

3. Specific sport played in college

4. Ethnicity

5. Gender

6. High School Core-Course Grade Point Average

7. Score attained on SAT or ACT test.

\section{Summary of Procedures}

This study analyzed characteristics presented in the literature of increasing potential and expectancy of NCAA Division I intercollegiate athletic student athlete graduation from college. These characteristics were based on previous research and studies that explored this phenomenon. The researcher then analyzed if data from the literature could be generalized to the Mid-American Conference based upon detailed analyses of self reported data provided by student athletes in the conference. Mid-American Conference student athletes within one academic year of graduation and in their last season of athletic eligibility were selected to be examined $(\mathrm{N}=1430)$. A stratified proportional random sample of $25 \%$ of the total population was then used to select the specific sample to receive the instrument $(n=358)$. One-hundred ninety one surveys, or $54 \%$ were returned to the researcher for data analysis. 


\section{Demographic Data}

The database for this study consisted of demographic data obtained on $n=358$ student athletes in the Mid-American Conference. Data included gender, ethnicity, current academic standing, expectation of graduation and expected date, sport played in college, athletic scholarship status, score attained on SAT and/or ACT, NCAA core-course grade point average as determined by the NCAA Clearinghouse, and current cumulative grade point average in college. The surveyed population included senior, by NCAA definition, student athletes in the Mid-American Conference representing 27 total sports.

Data relating to the research question and the predictors and characteristics of enhancing potential of graduation for an NCAA Division I student athlete were based upon a randomly selected stratified proportional sample $(n=358)$ of the population of 1430 student athletes who met the desired criteria. One hundred ninety-one student athletes returned the survey in the prescribed time frame. The responses were presented and answered on a self reported survey instrument developed by the researcher and inspired by existing questionnaires on student athlete graduation rates and previous research and literature. Answers to the demographic data were coded on SPSS, version 10.1 as needed in relation to the specific questions.

\section{Summary of Findings and Conclusions}

From an overall perspective, this research addresses several interesting issues relating to the potential for and expectancy of graduation for NCAA Division I student athletes and how those issues relate to student athletes in the Mid-American Conference. These results are discussed in the following section:

There are several issues concerning the profile of a senior Mid-American 
Conference student athlete development from the survey instrument and statistical analysis research based conclusions that can be generalized based on information in the literature and previous research. The data analysis performed on the student athletes in the Mid-American Conference overall confirm the characteristics and predictors of student athlete academic progress and graduation presented in the literature and previous research. Inferences on the hypothesized research question and the seven characteristics that influence graduation of a NCAA Division I student athlete were based on the literature and the various statistical techniques utilized in this research. Analysis of the data supports previous research and literature on predictors of graduation and academic achievement of student athletes. This specific population is much more likely to graduate due to the fact they are all within one academic year of receiving their baccalaureate degree (Tinto, 1987). An examination of the research question in conjunction with the seven characteristics or predictors of graduation explores the relationship to what is presented in the literature.

Student Athlete's Perception of College Coaches Emphasis on Academics

The literature is clear on the point that coaches, in particular the head coach of a specific athletic team, can have a major impact on the academic success of the individual student athlete (Adler \& Adler, 1985; Briggs, 1997; Petrie \& Russell, 1995; Thompson, 1991). An analysis of each question relating to college coaches' emphasis on academics was done using a descriptive statistics frequency cross tabulation by sport, gender, ethnicity, and answer given on the survey instrument. On the questions that covered recruiting of the student athlete prior to college enrollment, almost $50 \%$ of the athletes, representing all sports, who answered the question, said they believed their college coach made academics the number one priority during the recruiting process (Table 1). This corresponds with the literature in that most coaches do emphasize the 
academic importance of college and graduation to prospective student athletes, however according to previous studies and research, that goal appears to change to one of eligibility maintenance solely for competitive eligibility when the student athlete is enrolled in college (Adler \& Adler, 1985; Sperber, 1990).

Studies indicate that the influence of coaches emphasizing academic success and graduation among their student athletes is significant to the academic progress of a student athlete (Adler \& Adler, 1985; Briggs, 1997; Petrie \& Russell, 1995; Thompson, 1991). The literature indicates that coaches will strongly push academics and academic programs on prospective student athletes during the recruiting process (Adelman, 1990; Adler \& Adler, 1991; Briggs, 1997; Purdy, 1981). The same studies also state that academic emphasis by coaches significantly decreases upon the prospect enrolling in college, specifically among revenue sports (Maloney \& McCormick, 1992). The data presented from the student athletes in the Mid-American Conference is consistent with the literature on the subject of academics being emphasized during the recruiting process and that the emphasis lessens upon enrollment of the student athlete when the analysis includes sports in addition to football and men's basketball. Almost $90 \%$ of the respondents from all of the sports surveyed agreed or were neutral on the questions that asked about the level of emphasis on academics by coaches during the recruiting process. Less than 10 $\%$ disagreed with the questions.

The changes that coaches have with regard to emphasizing academics after college enrollment of their student athletes in the literature is also found in the data provided on the survey instrument by student athletes in the Mid-American Conference. While overall the student athletics in the Mid-American Conference said their coaches maintained the priority emphasis on 
academics and not athletics (almost 50\%), only $31 \%$ believed that their coach was more interested in them graduating from college than their competitive eligibility (Table 4).

Overall, the Mid-American Conference coaches of the 27 sports represented on the survey stress academics and graduation more than athletic success. These research-based conclusions confirm that the results gleaned from the literature can be generalized to the MidAmerican Conference when discussing overall impact of this characteristic on all student athletes and all sports represented on the survey.

When student athletes' perceptions of college coaches' emphasis on academics is further broken down into the subgroups of revenue and non-revenue sports there are some different results. Over $50 \%$ of football players believed their coaches were more interested in keeping them eligible for competition rather than progressing academically. The men's basketball respondents differed from the literature and answers provided were very positive towards the coaching staff before and during college enrollment. Overall there is no significance through statistical analysis of student athletes' perceptions of college coaches' emphasis on academics when comparing all teams, but there are differences noted in the sport of football as opposed to men's basketball. Table 3 shows that while $85.3 \%$ of the respondents answered agree or neutral to question 14, "After college enrollment my coach placed academic success above athletic success," there is a decline in agreement in the sports of men's basketball and football in comparison to the responses of non-revenue sport student athletes. Of 48 football respondents to the question, 21 agreed that academics were placed above athletic success, but 27 were either neutral or disagreed with the question. In men's basketball, the decline is similar versus the perception prior to college enrollment. Seven out of the 11 men's basketball respondents were either neutral or disagreed with the question. 
On Question 22, "My coach is more concerned with my graduation that for my eligibility to play," is significant in that only $30.9 \%$ of the student athletes surveyed in all sports agree that their coach is more concerned with graduation than competitive eligibility (Table 4). Still a very high percentage (64\%) stated on question 23 (Table 5) their coach would be concerned with in their academic success once eligibility expired. This is in conflict with the literature in the case of revenue sports where research indicates coaches detach themselves from their student athletes once their eligibility expires and they know they can no longer assist them athletically (Adler \& Adler, 1985).

The literature indicates that due to the high pressure put on coaches in revenue sports to win games, often the focus on academics becomes less (Adler \& Adler, 1985, 1991; Briggs, 1997; Broadhead, 1992; Purdy, 1981). The data in Table 4 is consistent with the literature on most of the questions in that the influence of the coach on academics and graduation can be influential to a student athlete. Reponses to questions 22 and 23 in particular show that certain revenue sport coaches are more concerned with winning and keeping players eligible than with graduation. Over half of the football respondents to these questions believed that their coaches were more interested in keeping them eligible, than seeing them graduate. The majority of the football players also noted that they believed that their coach(es) would lose interest in their academic progress once their eligibility expired. It is important to note however that the majority of the men's basketball responses on the instrument were positive towards the coaching staff, which does not correspond with the literature.

The data overall identifies a trend of almost all coaches in the Mid-American Conference emphasizing academics during recruiting (Table 2). The academic emphasis appears to decline for students in the Mid-American Conference after college enrollment, especially in football, as it is 
presented in the literature for other student athletes in NCAA Division I. Overall, as shown on Table 16, there is no significant difference when performing a one-way analysis of variance on all groups concerning college coaches' emphasis in academics. The differences that do exist are primarily in the sport of football, but the data overall shows that Mid-American Conference coaches are generally more concerned with academic progress and graduation of student athletes than athletic success.

\section{The Extent of Use of Academic Support Services for Student Athletes}

Student athletes who use specialized academic support services designed specifically for their needs, have a much greater chance of academically succeeding in college since many student athletes are not prepared to do college level work (Briggs, 1997; Naughton, 1997). The literature identifies many key points in how specialized academic support services can assist even a marginal academic level student to successful progress in college. Questions 43-56 on the survey instrument relate to the extent that student athletes use these services. A thorough analysis of the subgroups within the population by sport, by ethnicity, by gender reveals more specifically which subgroups use the services. Several inferences can be made from the data in relation to the literature on the impact these services can have on the academic success of an individual student athlete. The literature states certain subgroups that have higher test scores and GPAs were less likely to use the services and indicate they do not need these services to graduate (Benson, 1994, 1997).

The characteristic of extent of use of academic support services for student athletes, like the other characteristics, is impacted by gender, ethnicity, and the sport played in college. In the literature and previous research, males will typically use specialized academic support services for student athletes more than females, African-Americans use these services more than 
Caucasians, and revenue sports participants use these services more than non-revenue sports (Benson, 1997; Naughton, 1997). The data reported by Mid-American Conference student athletes is similar to the literature. A one-way analysis of variance of all groups shows no significant difference between all groups in the population, but again specific subgroups of the population, males, African Americans, and revenue sports participants, show significant use of and a belief that they need these types of services to be academically successful in college and graduate.

The literature states that student athletes who are defined as academically at risk, by having a low NCAA core-course grade point average and sub standard entrance exam score, will use these services more, however even academically strong student athletes will use these services because of the special academic needs student athletes require (Naughton, 1997). This characteristic is impacted by revenue and non-revenue sports participation, gender, and ethnicity. Previous studies signify that what sport played in, gender, and ethnic background are significant factors in who primarily uses these academic centers for student athletes.

The data self reported by student athletes in the Mid-American Conference signify that an academically at risk student athlete, who is a male minority, and who plays in a revenue sport is more likely to use these services. This is similar to what is presented in the literature (Benson, 1994). Several of the student athletes who met this profile stated they could not graduate without using these services. Fifty percent of all African-Americans, 31\% of all males agreed that they needed these services to be academically successful and to one day be able to graduate.

Questions 45 and 46 asked the respondents if they felt they could not graduate without being able to access specialized academic support services specifically tailored to student athletes. When cross-tabulating the questions with ethnicity, the data from the survey instrument indicates 
similar information presented in the literature. Out of 38 African-Americans who responded to question 45, "I could not graduate without use of these services," $50 \%$ agreed with the questions. Only 27 out of 143 Caucasians agreed with that statement (19\%). Question 46 asked, "I do not need these services to graduate." Similar data was received in response to this question. Tables 17 and 18 present a complete analysis of the responses by ethnicity.

Only $33 \%$ of the students surveyed purported to use the services available on a regular basis. However, the data do show that specific subgroups that fit the profile of being a more academically at risk student athlete use these services more. The student athletes who are minority, male, play on revenue sports team, and possess lower GPAs and entrance exam scores are more likely to use these services. Many in these subgroups feel that they could not graduate without being able to use these services. Conversely, the characteristic of gender is not as significant of an indicator of use of academic support services, but overall the data is representative of what is presented in the literature. Using the same two questions through a gender cross tabulation analysis, male student athletes in the Mid-American Conference use the services on average more than females. Twenty-one percent (19 total) of the 90 females that responded to the question agreed that they could not graduate without use of these services, while $31 \%$ (31) of the 100 male students that responded to the question. However, more females stated they could not graduate without the use of these services as stated in question 46 . Specific Sport Played in College

As stated in the literature, academic performance and graduation rates of student athletes in the revenue sports of football and men's basketball are much lower than other revenue and non-revenue sports (Benson, 1997; McMillen, 1991). The data gathered by the researcher in the Mid-American Conference are similar to the literature in that revenue sports participants score 
lower on many of the examined characteristics in particular the ACT, SAT, core-course grade point average, and current college grade point average. The results by gender and ethnicity in the sports of football and men's basketball are also similar in that the data indicate that African Americans and males score lower on many of the characteristics that can enhance potential for graduation from college (Benson, 1997). This is attributed to the commercialism of the sport and the intense pressure to create winning teams rather than the academic success of the student athlete. This attitude can change the focus of the coach, school administrator, or athlete toward athletic, not academic success (Broadhead, 1992; Pascarella, et al., 1995).

Questions relating to specific sport played are covered in questions 29-42 on the survey instrument. Several issues are addressed including the importance of academics, time spent studying, and if the specific sport competed in interferes with academic success. For the purposes of this study, five sports are represented on Table 10. The five sports are football, men's and women's basketball, synchronized skating, and field hockey. The researcher chose these sports to show achievement primarily along gender lines combined with the specific sport played.

Again the data support the literature in that the responses are different for different subgroups. The Mid-American Conference, as in the literature, has lower academic achievement from its football and men's basketball players. Many of the athletes who play revenue sports did not indicate that academics are their top priority in college. Table 10 refers to selected sports showing the differences, through descriptive statistics, between revenue and non-revenue sports on the academic indicators of ACT/SAT score, NCAA core-course GPA, and current GPA.

\section{Ethnicity}

Ethnicity is one of the most important characteristics mentioned in the study given that it is cited in the literature as a significant predictor of academic success in college (Benson, 1994, 
1997). The analysis for this study by ethnicity focused on African-American academic performance in NCAA core-course grade point average, ACT/SAT scores, and current college GPA. No other ethnic group is examined specifically due to the low number that responded to the survey instrument. According to the literature and previous research, Caucasians score higher other minority groups in these four areas, specifically more than African Americans ("The Academic Performance,” 2000).

The results posted on Tables 21, 22, and 23 correspond with the literature showing African Americans, specifically males, score lower in all of the four aforementioned areas. The difference is even more pronounced in the sports of men's basketball and football. Both sports present significant differences between the ethnic groups on the four areas of academic achievement used for this study.

A test of significance between Caucasians and African Americans in the sports of football and men's basketball on the four academic areas was performed through a one-way analysis of variance. The data reflected in Table 23 reinforces the descriptive statistics in that there is a significant difference between the subgroups based on ethnicity, representing all sports in the survey, in three of the four areas, excluding the score attained on the SAT test.

Gender

Gender is another characteristic that is likely to influence a college student's educational achievement in college and graduation (Adelman, 1990; Astin, 1993; Pascarella \& Terenzini, 1991). The literature and previous research strongly indicate that females will have higher academic achievement in high school and college. Female student athletes also have higher overall college grade point averages, entrance exam scores, and NCAA core-course grade point average (Benson, 1994, 1997). 
The data reported from the Mid-American Conference is similar to the literature regarding gender in the four main areas of academic achievement. Table 24 presents through a t-test analysis, using all sports that were represented by the population, which female student athletes score higher on the ACT/SAT, overall college grade point average, and NCAA core-course grade point average. The data presented in Table 26 supports the literature and data in Table 24 by reinforcing the differences by combining gender, ethnicity, and specific sport played in college. The data from the Mid-American Conference listed on Table 25 differ from the literature in that the achievement of females in women's basketball, specifically Caucasian females, is lower than Caucasian males in three of the four descriptive academic areas, except for current college GPA. Previous research strongly indicates that females, specifically Caucasian females in any sport, score higher in these areas that Caucasian or African American males ("American Institutes for Research," 1989; Purdy et al., 1985; Simons, Van Rheenen \& Covington, 1999). The analysis of variance presented in Table 26 corresponded with the descriptive data showing a significant difference between the groups, excluding the SAT score. No African American females in this particular population that returned the survey instrument took the SAT, preventing an accurate assessment of its significance on these subgroups.

NCAA Core-Course Grade Point Average

High school grade point average, specifically a grade point average of at least a $2.0 \mathrm{in}$ college preparatory classes, is often operationalized as a major predictor of academic achievement, persistence, and potential for graduation from college (Benson, 1994, 1997; Nettles, Theony \& Gosman, 1986; Petrie \& Russell, 1995; Sowa, Thompson \& Bennett, 1989; Tracey \& Sedlacek, 1984, 1985, 1987; Wilson, 1981). The data in this study would then seem to support previous research and literature that indicates an increased chance of dropping out of school if a 
particular student is at risk academically. An at-risk academic student can be indicated by a low high school grade point average along with other characteristics (Benson, 1994, 1997; Purdy, 1981). Since the surveyed population is primarily represented by NCAA core-course grade point averages above 2.5 , this characteristic can be generalized to the literature in that it is a significant predictor of making it to the last two years of college, which in turn greatly increases the potential for graduation (Simons, et al., 1999; Ting \& Robinson, 1988; Tinto, 1987).

In what is similar to the breakdown of the entrance exam scores of this population, very few of the respondents have a core-course grade point average below 2.0 ( 2 out of 165). This supports the literature in that those who have a low core-course grade point average are more likely to drop out of school before the senior year, while those with the higher grade point average are more likely to persist and graduate (Benson, 1994, 1997). Table 13 shows only 19 of the 165 of the surveyed population who responded to the question had a core GPA of 2.5 or below, and only two respondents reported having a core-course GPA below 2.0. This is an indicator that a higher college preparatory GPA increases the chances of graduating from college. The results from the data are very similar to what is presented in the literature. A $2.5 \mathrm{GPA}$ in 13 college preparatory classes is needed in combination with a minimum ACT or SAT score to be competitively eligible for intercollegiate athletics during the initial year of enrollment. A 2.0 corecourse GPA may be good enough for initial eligibility, but a higher test score is needed when used for NCAA initial eligibility requirements (Appendices A and B)

\section{ACT/SAT Test Score}

Previous research strongly indicates that the score achieved on the ACT and/or SAT significantly predicts the ability to perform academically in college and increases the chances of graduation (Benson 1994, 1997; Jacobson, 2001; Purdy et al., 1981). The data presented by the 
Mid-American Conference population are consistent with the literature in almost every aspect relating to student athlete performance on the entrance examinations. First in a one-way analysis of variance analyzing scores by ethnicity and gender in the revenue sports of football and men's and women's basketball, the data show a significant difference between groups in the ACT score. The SAT difference is not significant in any group, however the data are similar to what is presented in the literature in that it has African American males as the lowest scoring subgroup

It is important to note again that all of the student athletes who responded to the survey are within one academic year of graduation and very few in the population had an ACT score below 17 ( 2 out of 122), which would be the minimum acceptable score for initial eligibility with a 2.5 GPA, or an SAT score below 800 (1 out of 76), which would also be the minimum score needed in conjunction with a $2.5 \mathrm{GPA}$ for initial NCAA eligibility. These data would generalize from the literature and previous research that cite that a higher entrance exam score increases the likelihood of persistence and graduation from college (Tinto, 1987). Previous research indicates the combination of a test score and grade point average are the prime indicators of success or failure in the first year of college (Purdy, 1981). Since the test scores gleaned from the data are generally higher than 17 on the ACT and 800 on the SAT, the data would correspond with the literature that higher entrance exam test scores improve the potential of persistence and graduation for all students and student athletes (Benson, 1994, 1997).

The data also present relevant information on individual revenue sports combined with other characteristics and score attained on the ACT or SAT. The data are consistent with the literature, as football and men's and women's basketball overall have lower mean entrance exam scores than other 24 sports represented in the population. African Americans in football and men's basketball score lower on the tests than Caucasians in the same sports. Typically, these 
two sports overall have the lowest entrance exam scores of all sports in NCAA Division I (Lapchick \& Slaughter, 1989; Sperber, 1990, "Study Shows," 2001). The data in this study are consistent with the literature that strongly indicates that the graduation rates in the sports of football and men's basketball are much lower than any other sport in intercollegiate athletics, and much of that has been attributed to poor preparation and inability to do college-level work. This is many times indicative of a low entrance exam score (Maloney \& McCormick, 1992).

\section{Ancillary Findings}

There are several findings that were not specifically sought out in the research question. Much of the ancillary data came from performing analyses across characteristics, using the constructs of ethnicity, gender, and sport played in analyzing the other characteristics to provide a better, more thorough analysis. Ancillary findings such as these present a forum for additional, more in-depth research using each characteristic and cross tabulating certain characteristics with one another.

The data reveal important generalizations that can be applied to the Mid-American Conference and support research based conclusions. The data imply many similar findings that support characteristics that enhance the potential for graduation of student athletes in the literature. The data support that the most likely student athlete graduate is one that plays in nonrevenue sport and who has a higher core-course GPA and entrance exam score. However, one that is academically at risk and uses academic services for student athletes can offset poor GPA, test scores, and sport played by making it to the junior and/or senior year of college significantly increasing the likelihood of graduation.

Another ancillary finding discovered through the research for this study was that Caucasian females scored lower overall than Caucasian males on NCAA core-course grade point 
average and test scores in the sport of women's basketball compared to football and men's basketball (Table 25). This is contrary to the literature, which is consistent that females rate consistently higher on the constructs of ACT/SAT score, NCAA core-course grade point average, and current college grade point average in all sports. Table 19 reflects what is becoming a disturbing trend in NCAA Division I intercollegiate athletics. That trend is one of women's basketball becoming more popular and generating more revenue and commercial sponsorships, making a sport where winning is rapidly becoming more important that the academic well-being of the student athletes.

Despite indications in the literature and data that coaches are a major influence over the academic lives of student athletes, only $10 \%$ of the respondents to question 27 on the survey instrument answered agree to the question, "My coach is the person who has the most academic influence over me." This could be that even though the data indicate the coaches that are represented in certain subgroups, emphasize academics during recruiting but relent once college enrollment starts, individual student athletes rely on themselves or others for academic influence. Many responded via a space provided for written comments on the survey instrument that they are in control of their academic and athletic life, while others cited that athletic academic advisors have the most academic influence over them (21\% agreed on that subject for question 56). Many written answers indicated that the athletes feel their coaches do not care about academics, but since it is important to them, they focus on it and rely on themselves.

The data also reveal many important reasons why this population's potential of persistence and graduation is significant. Seventy-three percent of the respondents said the importance of academics was stressed in high school. The literature cites substandard high school academic preparation, specifically in college preparatory classes, as one of the main 
reasons prospective college students score poorly on the ACT/SAT test, and are more likely to drop out of college within the first two years of enrollment (Benson, 1994, 1997; Nettles, Theony \& Gosman, 1986; Petrie \& Russell, 1995; Sowa, Thompson \& Bennett, 1989; Tracey \& Sedlacek, 1984, 1985, 1987; Wilson, 1981). The data indicate that the majority of the student athletes in the population had sufficient academic preparation in high school to succeed in college.

Almost $70 \%$ answered agree to the questions that asked whether they were regarded as a serious student and if academics were their top priority in college (Questions $37 \& 38$ ). This was even evident in revenue sports where the literature and previous research indicate that many student athletes in these sports focus more on a professional athletic career rather than graduation from college (Briggs, 1997). Only $26 \%$ of the respondents indicated they chose their specific school for athletic and not academic reasons. Another 25\% were neutral, but almost 50\% indicated they chose their school for reasons other than athletics. As seen in the descriptive data, the overall profile of the population is academically strong enough for all respondents to graduate. There are some weaker academic individuals in the population, as indicated by the $13 \%$ that needed summer school courses to remain eligible, but the literature indicate they will likely graduate since they have succeeded to this point academically (Tinto, 1987).

Several of the respondents (14) to the survey took time to annotate written comments about the survey overall and certain questions. In the area of college coaches' emphasis many of the written comments stressed that student athletes should be responsible for themselves academically and relying on someone else is only going to cause problems. These comments were interesting in that many came from participants in male revenue sports, who according to 
the literature receive a disproportionate amount of attention from their coaches to persist academically so they can maintain eligibility.

Some of the student athletes in their written comments stated that their coaches were encouraging academic success while others criticized the coaching staff of their particular team for expecting good grades, but not giving time and encouragement for members of the team to meet that expectation. Also some indicated that the coaches are interested in academic success and graduation for their student athletes, but only during the off-season. This finding was interesting in that comments like this were primarily from females who participate in nonrevenue sports.

Most written comments were very positive about the assistance of specialized academic support services for student athletes. Several of the student athletes lauded the encouragement of these advisors keeping them on track to graduate and pushing academics when many others, like the coaching staff, were more focused on athletic success. Even in the case where a particular student athlete did not use the services on a regular basis, some comments reflected how important that all athletes think these services are due to the fact that many of the student athletes have very time consuming practice and competition schedules that can leave little time for studying.

Issues relating to sport played, gender, ethnicity, GPAs, and score attained on the ACT or SAT test were not addressed in the written comments, however, the descriptive information is indicative of what is presented in the literature in that those who are male, minority, and who participate in a revenue sport have lower GPAs and test scores and are more likely to say there coaches have a large amount of academic influence and that they use 
specialized academic support services more than those who are more likely to not be academically at risk (e.g. female, Caucasian, who competes in a non-revenue sport).

Theoretical Basis

This study drew upon Vroom's expectancy theory (Vroom, 1964). This theory is applied to this study by measuring the expectancy of graduation by each of the respondents and to examine if pre-determined characteristics, cited prominently in the literature, are related to motivation of student athletes to graduate from college. All student athletes, except one, who responded to the survey, stated they expect to graduate from college. This indicates that the respondents are motivated and expect to graduate. Vroom's concept of expectancy refers to the strength of a person's belief about whether or not a particular performance is attainable. Clearly, the data indicates that the respondents expect to graduate and that can be attributed to several factors.

First, all of the respondents are within one year of graduation. Previous research indicates that students and student athletes who are in college longer are more likely to graduate and the expectancy of graduation increases (Pascarella et al., 1996; Tinto, 1987). Pascarella (1996) also noted that athletic participation may increase the motivation to stay competitively eligible and graduate. Several of the respondents in this study remarked through written comments that intercollegiate athletics were a primary reason for attending college and staying on track academically. In a sense the sport then motivated these student athletes to stay in college, increasing the expectancy of graduation. Overall, student athletes in the Mid-American Conference state they came to school for academic reasons, but they indicate that intercollegiate athletics is important to them which in turn can still serve as a motivational factor even though it is not the primary emphasis. 
Secondly, the theory can also be applied to the seven characteristics of academic achievement and potential of graduation for NCAA Division I student athletes examined in this study. The emphasis that a college coach puts on academics and graduation of his or her student athletes can affect the motivation toward achieving academically and graduating for an individual student athlete. Previous research cited the coach as being the most prominent role model for a student athlete in college (Adler \& Adler, 1985). If that role model emphasizes athletic success over academic achievement, the motivation of a student athlete may change toward pleasing the desires of that prominent role model. This also correlates directly with the specific sport played in college in that athletic achievement in revenue sports is of primary concern to coaches and administrators. That emphasis can also decrease the motivation and expectancy of graduation if a student athlete in a revenue sport is given positive reinforcement from his coach and others based only on athletic success.

Thirdly, the other characteristics are also impacted by the expectancy theory. While the sport played and coaches emphasis on academics figure prominently in the theoretical basis for this study, other mentioned characteristics can impact the motivation and expectancy of graduation for NCAA Division I student athletes. One characteristic that can increase motivation and expectancy of graduation is the extent of use of specialized academic support services for student athletes. These services can expose student athletes to other role models whose emphasis is academic, not athletic achievement. Academic advisors that work in these centers were noted by many of the respondents as having a major impact in keeping them on track for graduation. Positive academic role models such as these can assist in motivating and increasing the expectancy of graduation for those that use these services and as mentioned previously can offset other academic distracters that may inhibit achievement or graduation. 
The other characteristics may also enhance or inhibit the motivation and expectancy of graduation for NCAA Division I student athletes. The characteristics that measure academic achievement for this study can also be impacted by this theory in that a high current or corecourse GPA, and a high score on the SAT or ACT not only increase the probability of academic success in college but can also increase motivation and expectancy of graduation. Vroom (1964) stated that probability of success in achieving a certain outcome increases the expectancy to achieve that outcome. If one is an academically at risk student athlete, rather than not at risk, the expectancy of academic achievement in college and probability of graduation can be decreased based upon past academic record. Previous research has suggested that degree aspirations at the time of college enrollment are the most potent predictor of graduation from college (Astin, 1977). Student athletes, who have low degree aspirations, or low expectations or desire to achieve academically and graduate from college, may lack the motivation to achieve the outcome based upon a lower academic standing and being academically at risk.

The other two characteristics of gender and ethnicity may also affect motivation and expectancy of graduation. The literature shows that females score higher on the surveyed areas of academic achievement and that alone may increase the expectancy and motivation towards graduation since females show that by higher achievement on the predictors of graduation they are more likely to graduate. Minorities, mostly African Americans, are cited in this study and previous research as a subgroup that consistently scores lower on the surveyed areas of academic achievement which puts them more at risk academically than student athletes who are Caucasian. As with the other characteristics that act as a potential inhibitor or enhancer to graduation from college, ethnicity can increase or decrease the expectancy for graduation from college since 
certain subgroups of ethnic backgrounds score markedly higher or lower than other comparable ethnic groups.

Student motivation is considered to be a determining factor in academic performance, persistence, and graduation (Geiger \& Cooper, 1996). The seven characteristics that influence academic achievement and graduation from college examined in this study are directly influenced by a student athlete's motivation and expectancy toward graduation from college. The seven characteristics can significantly affect the motivational factor of and individual student athlete in that some characteristics may act as an inhibitor to academic success in college, while others may actually enhance the probability. For another student athlete the opposite may be true and he or she may have their motivation and expectancy affected differently by the effect of different characteristics. Previous research and this study confirm that motivation toward and expectancy of graduation from college in combination with all or some of the seven characteristics increase or decrease the potential for graduation from college. To that end, the literature pertaining to motivation and expectancy with regard to academic achievement and graduation from college for an NCAA Division I student athlete can be generalized to the student athletes of the Mid-American Conference.

\section{Discussion and Implications}

\section{Discussion}

The basis for this study was to present data collected on NCAA Division I student athletes in the Mid-American Conference to ascertain if the student athletes represented in the survey fit the profile of student athletes presented in the literature so that findings in the literature and previous research can be generalized to the student athletes in the conference. The characteristics examined in this study were student athlete's perception of college coaches' 
emphasis on academics, the extent of use of specialized academic support services for student athletes, specific sport played in college, ethnicity, gender, NCAA high school core-course grade point average, and score attained on the SAT and/or ACT. Each of these seven characteristics are indicated through previous research and this study to have a potentially significant impact on the potential for academic achievement and graduation from college for all NCAA Division I student athletes, including the ones represented in this study.

This analysis supports previous research that contends NCAA high school core-course grade point average and entrance exam scores appear to have a great impact on increasing potential for graduation. Those student athletes that score low on these two characteristics and/or do not score high enough to meet NCAA initial eligibility requirements are typically those that are at risk for not graduating. Since members of the surveyed population are all within one year of graduation, it indicates that overall the population should have generally higher GPAs and test scores since they have made it to this point. The overall scores represented in the population show few GPAs below 2.0 or test scores below 17 ACT/800 SAT. This finding supports the literature in that it strongly indicates those student athletes with higher GPAs and test scores are more likely to graduate from college.

The results of this study support the supposition that the results are similar to the literature through the other specific characteristics. Gender and ethnic background are cited as significant predictors of graduation for all students and for NCAA Division I student athletes. The results of this study support that conclusion in that there are significant differences in achievement on core-course GPA and entrance exam score between males and females and Caucasians and African Americans. Previous studies indicate that females have higher academic achievement in college and minorities typically come from disadvantaged primary and secondary 
educational backgrounds that may inhibit their potential for success. The findings in the literature and this study are similar to the findings overall for college students on potential of graduation for NCAA Division I student athletes.

The sport played in college is cited in the literature as a significant predictor of academic achievement and graduation. This study is consistent with previous research that presents much lower graduation rates in the sports of men's basketball and football than any other sport in NCAA Division I. The data for this study confirm the literature in that student athletes on these two teams have lower GPAs and test scores, but the revenue sport student athletes from the MidAmerican Conference are very likely to graduate since they have made it to their last academic year of college. One potential factor contributing to this success might be the availability of specialized student athlete academic support services at most NCAA Division I institutions, something that all 13 schools of the Mid-American Conference possess. Most of the student athletes in the category of academic at risk (low GPAs and test scores), who play in a revenue sport and minority and/or male use these services more than student athletes who are not at risk. It would be hard to discount the impact of these services in assisting an academically at risk student athlete in persisting in college and graduating. Many student athletes in this study, who fit the profile of an academic at risk student athlete, used these services and indicated they could not graduate without the ability to use these services. Similar data are presented in the literature.

The most interesting part of this study is how the characteristics, or combinations thereof, can enhance or decrease the potential of graduation for an NCAA Division I student athlete. The data presented interesting findings that supported the literature and previous research on areas that need to be emphasized for an intercollegiate athletic administrator to enhance the graduation rates of NCAA Division I student athletes. 


\section{Implications}

As stated in the literature and previous research, the graduation of intercollegiate student athletes is of significant concern to those in charge of intercollegiate athletic programs. The reasons student athletes academically achieve and graduate or do not achieve and graduate have been examined in many studies. In analyzing the literature, this study forms research-based conclusions about student athletes in the Mid-American Conference to ascertain if information in the literature can be generalized to student athletes in the conference.

The researcher believes that this study confirms most of the data presented in the literature. The implications of this study apply primarily to the Mid-American Conference, but the results can be generalized to student athletes in other conferences since the data presented in this study shows that the affect of the characteristics is consistent from the literature to this study. In turn, intercollegiate athletic administrators attempting to design and apply programs and strategies to enhance the graduation rate of NCAA Division I student athletes can use the results of this analysis.

The graduation rates of intercollegiate athletes at a particular institution have long been used as a measurement of the academic emphasis concerning intercollegiate athletics. The findings of this study revealed certain characteristics, also identified in the literature that can enhance the graduation rates of student athletes. These findings suggest that college presidents, athletic directors, coaches, and other higher education administrators must be aware of factors that can improve the academic achievement and graduation rate of student athletes. Government leaders must be aware of certain socio-economic factors like ethnicity that significantly inhibit the potential of graduation for a student athlete. 
Most notably, higher education institutions must be brave enough to admit only prospective student athletes who are capable of doing college level work and handling the rigors of intercollegiate athletics. Currently, due to the popularity of intercollegiate athletics at some institutions and the power of coaches and boosters involved in intercollegiate athletics, many higher education and government officials are reluctant to do anything that changes the athletic emphasis on some student athletes in certain sports. Specifically, if a prospective student athlete meets the definition of academic at risk, the institution can take proactive measures, such as requiring the use of student athlete academic services, to increase the potential of academic success and graduation. Federal, state, and local government leaders can take action to start and improve programs that increase college preparatory grade point average, and entrance exam scores. These programs can be tailored specifically to males and minorities since this subgroup is significantly more at risk to be substandard academically.

From the perspective of educational administration, higher education administrators, and those involved in intercollegiate athletics there are several options for improvement in intercollegiate athletics using information provided by this research as a tool. Higher education administrators must implement the administrative functions of planning, organizing, staffing, directing, coordinating, reporting, and budgeting (Gulick \& Urwick, 1937). The data provided in this study, if used to implement plans for improvement, would have impacts on all of these areas. For example, almost any improvement would impact all seven areas of administrative functions. Potential actions that can be taken due to this study are coaches' contracts can be structured in a way that emphasizes the importance of academics and graduation, facilities and services must be made available and sufficient for at-risk student athletes, academically failing student athletes must not be allowed to play until minimal satisfactory progress and GPA 
standards are met, and focus more on primary and secondary education to improve the academic preparation of students and student athletes who desire to attend college.

Regardless of the plans for improvement, college athletics are here to stay. With the increasing emphasis on generating revenue and winning games, the impetus for academic achievement is becoming less and less. Those who are in control of intercollegiate athletics must realize that sacrificing academic integrity and the future lives of student athletes for short-term gain is not the proper way to address a growing problem of student athletes in certain sports not graduating or achieving academically. The way to address this situation is to apply the characteristics and predictors of academic achievement and graduation prevalent in this study and previous research to insure that the right balance between academics and athletics remains and that a prospective student athlete has the best chance to be academically successful and receive a baccalaureate degree while still enjoying academic success.

\section{Limitations and Recommendations for Further Research}

\section{Limitations of This Research}

The main limitation of this research is that it does not have the measurement of graduation to ascertain if the characteristics, presented as independent variables, would have an effect on a dependent variable of graduation. As of the administration date of the survey instrument, only 12 of the student athletes had received a baccalaureate degree. This study is a descriptive study that only assesses if the characteristics as presented in the literature can be generalized to student athletes in the Mid-American conference based upon research conclusions gleaned from this study. Having graduation or expectation of graduation would be a study of a stronger design than what a descriptive study presents. 
Several data items were based upon the recollection of the respondents. In the case of GPAs and entrance exam scores, specific data could have been obtained from the institutions, however anonymity could not be guaranteed as required by the human subjects exemption process at West Virginia University. The researcher believes that the recollection of this data will be close to exact because of the importance of those scores to incoming freshman student athletes.

The survey instrument was developed by the researcher and may lack the validity and reliability of an established instrument. Although the instrument was inspired by the literature, previous research, existing surveys on intercollegiate athletic graduation rates, judged by a jury of experts, and pilot studied, it was an instrument being used for the first time. The literature indicates that a single survey instrument used for the first time may lack the validity of an established survey instrument in measuring the data (Johnson \& Christensen, 2000). An analysis with stronger validity on this subject may be accomplished by using other survey instruments to support the data gathered by this instrument.

\section{Suggestions for Further Research}

Further quantitative and qualitative, empirical research, that traces the student athletes through all years of college enrollment and past college graduation would be a more thorough assessment of the effect of the characteristics on the academic achievement and graduation rates of NCAA Division I student athletes. The characteristics could then be used as predictors to determine if indeed the graduation rates of NCAA Division I student athletes are significantly impacted by the characteristics and predictors of graduation cited predominantly in the literature. The Mid-American Conference would be an ideal conference to study post graduation because of the propensity for the institutions to take more academically at risk, but athletically talented 
student athletes (Messer \& Cherry, 2000). A more thorough study would be an ethnographic and longitudinal study that follows a group of student athletes through their senior year in high school up to post graduation. This type of study would bring out the human factor in academic achievement and graduation of NCAA Division I student athletes. A study focusing just on coaches and their attitudes towards academic achievement, winning, would be an excellent addition to the body of knowledge. In addition, detailed research on specialized academic support services for student athletes analyzing which types of assistance are the most effective in improving academic achievement and for what groups and sports would also be a needed study. Also, the institutions of the Mid-American Conference are similar to each other but may not adequately represent other institutions in NCAA Division I. Further study of other conferences or a cross-conference analysis using a similar survey instrument would also be beneficial to add to the body of knowledge of this topic.

The sports of men's basketball and football figured prominently in the study. The literature indicates that student athletes in these two sports score lower on entrance exams, have lower GPAs, and use academic support services to a greater extent than others represented in the population. The literature and the data support that the pressure to win games and make money to support intercollegiate athletics in these two sports can make academics very difficult and secondary for a student athlete. The data relates to the literature in that members of these two teams do score lower on many of the characteristics, thus decreasing their potential for graduation but that might be offset by more extensive use of the specialized academic support services available to student athletes in the Mid-American Conference. The other sports and student athletes were representative of the literature on many of the characteristics, although Caucasian females in the sport of women's basketball were found to score lower of entrance 
exams and have lower GPAs than Caucasian males. A study examining the changing trends of women's basketball toward academic decline would be interesting. Further study on the specific phenomenons of the sports of men's and women's basketball and football is recommended due to the unique academic and athletic issues that surround these three sports. 


\section{REFERENCES}

A call to action: Reconnecting college sports and higher education: Knight Foundation

Commission on intercollegiate athletics. John S. \& James L. Knight Foundation: Miami, FL.

Adelman, C. (1990). Light and shadows on college athletes: College transcripts and labor market history. (Research Report). Office of Educational Research and Improvement. U.S. Department of Education: Washington, DC.

Adler, P. \& Adler, P.A. (1985). From idealism to pragmatic detachment: the academic performance of college athletes. Sociology of Education, 58(4), 241-250.

Adler, P. \& Adler, P.A. (1991). Backboards and blackboards: College athletes and role engulfment. New York: Columbia University Press.

Alley, L (1974). Athletics in education: The double-edged sword. Phi Delta Kappan, 56, 102-105.

American Institutes for Research. (1989). Results from the national study of intercollegiate athletes. Palo Alto, CA: Center for the Study of Athletics.

Alonso, R. (1993). The educator and licenses. European Education, 25(3), 81-97.

Ashe, A., and Rampersad, A. (1993). Days of grace. New York: Ballantine Books.

Astin, A. (1977). Four critical years. San Francisco: Josey Bass.

Beaver, W. (1996). Is it time to replace the SAT? Academe, 82(3), 37.

Benson, M.(Ed.). (1991). A graphic display of initial eligibility rules applied to 1984 and 1985 freshman student-athletes (NCAA Research Report 91-04). Overland Park, KN: National Collegiate Athletic Association. 
Benson, M. (Ed.). (1993). A statistical comparison of college graduation of freshman studentathletes before and after proposition 48 (NCAA Research Report 92-02). Overland Park, KN: National Collegiate Athletic Association.

Benson, M. (Ed.). (1994). Executive Summary of Reports 91-01 to 91-06 (NCAA Research Report 91-07). Overland Park, KN: National Collegiate Athletic Association.

Benson, M. (Ed.). (1995). 1995 Division I graduation rates summary. Overland Park, KN: National Collegiate Athletic Association.

Benson, M. (Ed.). (1997). Characteristics of student-athlete data in the 1994-95 NCAA initial eligibility clearinghouse (NCAA Research Report 96-02). Overland Park, KN: National Collegiate Athletic Association.

Benson, M. (Ed.). (1997). Characteristics of student-athlete data in the 1995-96 NCAA initial eligibility clearinghouse (NCAA Research Report 97-02). Overland Park, KN: National Collegiate Athletic Association.

Benson, M. (Ed.). (1998). Characteristics of NCAA division I recruits in the 1995-96 initial eligibility clearinghouse (NCAA Research Report 97-03). Overland Park, KN: National Collegiate Athletic Association.

Benson, M. (Ed.). (1999). Characteristics of NCAA division I recruits, including ethnic and income level groups in the 1995-96 initial eligibility clearinghouse (NCAA Research Report 97-04). Overland Park, KN: National Collegiate Athletic Association.

Benson, M. (Ed.). (1999). 1999 Division I graduation rates summary. Overland Park, KN: National Collegiate Athletic Association.

Blackburn, R. and Nyikos, M. (1974). College football and Mr. chips. Phi Delta Kappan, 56, 110113. 
Blum, D. (1994). Athlete's graduation rates lag at some division I colleges. The Chronicle of Higher Education. Retrieved September 21, 1999, from http://www.chronicle.com

Blum, D. (1995). Freshman eligibility. The Chronicle of Higher Education. Retrieved September 21, 1999, from http://www.chronicle.com.

Bowlus, W.C. (1975). How well do our college athletes fare? Journal of Physical Education and Recreation, 46(25), 22-32.

Broadhead, S. (1992). The student athlete crisis: Does the university have a duty to educate? BYU Education and Law Journal, 113-130.

Briggs, C. (1996). Differences in degree aspirations and attainment outcomes between football, basketball, and other intercollegiate athletes. Paper presented at the annual meeting of the Association for the Study of Higher Education, Memphis, TN. (ERIC Document Reproduction Service No. 402832).

Britz, P. (2000). 2000-01 Guide for the College Bound Student Athlete. Indianapolis, IN: National Collegiate Athletic Association.

Brown, G. (1999, November 22). NCAA answers call to reform. NCAA News, pp. A1-A4.

Brown, G. (2000, March 13). The graduation rate dilemma. NCAA News, pp. 14-15.

Byers, W. (1995). Unsportsmanlike conduct. Ann Arbor, MI: The University of Michigan Press.

Caldwell, D. (1999, March 21). Coaches call for change in wake of proposition 16 ruling. Dallas Morning News. Retrieved September 21, 1999 from http://www.dallasnews.com.

Campbell, D., \& Stanley, J. (1963). Handbook on research in teaching: A project of the American Educational Research Association. Chicago: Rand McNally \& Company. 
Cantor, N. \& Prentice, D. (1996). The life of the modern day student athlete: Opportunities won and lost. Paper presented at the Princeton Conference on Higher Education, Princeton University, Princeton, NJ.

Carodine, K., Almond, K., \& Grotto, K. (2001). College student athlete success both in and out of the classroom. New Directions for Student Services, 93, 19-33.

Chu, D. (1979). Origins of the connection of physical education and athletics at the American university: An organizational interpretation. Journal of Sport and Social Issues 3(1), 2232.

Chu, D., Seagrave, J., \& Becker, B., (Eds.). (1985). Sport and higher education. Human Kinetics Publishers, Inc.: Champaign, IL.

Clark, V., Horton, F., \& Alford, F. (1986). NCAA rule 48: Racism or reform. Journal of Negro Education, 55(2), 162-170.

Clarke, H. (1975). Athletics: Their academic achievement and personal social status. Physical Fitness Research Digest Series. 53.

Comments on federal court ruling on NCAA initial eligibility criteria. (1999). The College Board, 1-2.

Cross, H.M., (1973). The college athlete and the institution. Law and Contemporary Problems, $38,151-171$.

Crouse, J., \& Trusheim, D. (1988). The case against the SAT. Chicago: University of Chicago Press.

Cullen, F., Latessa, E. \& Byrne, J. (1990). Scandal and reform in collegiate athletics: Implications from a national survey of head football coaches. Journal of Higher Education, 61(1), 5064. 
Deford, F. (2001). Damning admissions: Two school presidents decry college sports and hit upon a larger problem. Sports Illustrated, 94(5), 40.

Dempsey, C. (2000, March 6). Proposition 16 remains in effect. National Collegiate Athletic Association Memorandum, 1-2.

Dodd, D. (1999). NCAA says changes should be coming on proposition 16. CBS Sportsline. Retrieved September 22, 1999 from http://www.cbssportsline.com.

Duderstadt, J. (2000). Intercollegiate Athletics and the American University. Ann Arbor, MI: The University of Michigan Press.

Eitzen, S., \& Purdy, D. (1986). The academic preparation and achievement of black and white college athletes. Journal of Sport and Social Issues, 10, 15-20.

Edwards, H. (1973). Sociology of sports. Homewood, IL: Dorsey Press.

Edwards, H. (1984). The collegiate arms race: Origins and implications of the 'Rule 48' controversy. Journal of Sport and Social Issues, 8, 4-22.

Engstrom, C. \& Sedlacek, W. (1991). A study of prejudice toward university student athletes. Journal of Counseling and Development, 70, 189-193.

Ervin, L., Sanders, S., Gillis, H., \& Hogrebe, M., (1985). Academic performance of student athletes in revenue producing sports. Journal of College Student Personnel, 26, (2), 119124.

Falla, J (1981). NCAA: The voice of college sports. National Collegiate Athletic Association: Mission, KN.

Ferrante, A., Etzel, E., \& Lantz, C. (1996). Counseling college student athletes: the problem, the need. Fitness Information Technology, 2. 
Figler, S. \& Figler, H. (1984). The athlete's game plan for college and career. Peterson's Guides: Princeton, NJ.

Frost, R (1973). "Forward" in Development of human values through sports. American Alliance for Health, Physical Education, and Recreation, 4.

Funk, G. (1991). Major violation. The unbalanced priorities in athletics and academics. Leisure Press: Champaign, IL.

Geiger, M.A., \& Cooper, E.A. (1996). Using expectancy theory to assess student motivation. Issues in Accounting Education, 113-129.

Gilbert, B. (1974, October). What counselors need to know about college and pro sports. Phi Delta Kappan, 56, 121-124.

Greene, H. \& Greene M. (2001, October). From our perspective: The true cost of intercollegiate athletics. Matrix for Leaders in Higher Education, 2(5), 11.

Gulick, L., \& Urwick, L. (Eds.). (1937). Papers on the science of administration. New York: Columbia University Press.

Haller, E. \& Kleine, P. (2001). Using educational research: A school administrators guide. New York: Longman.

Hanford, G. (1974). The need for a feasibility study of intercollegiate athletics. Washington DC: American Council on Education.

Hanford, G. (1979). Controversies in college sports. Educational Record, 60, 366.

Hanks, M. \& Eckland, B. (1976). Athletics and social participation in the educational attainment process. Sociology of Education, 49, 271-294. 
Harrison, J. (1976). Intercollegiate football participation and academic achievement. Paper presented at the Annual Meeting of the Southwestern Sociological Association, Dallas, TX.

Hazel, R. (2001). Marshall University Baseball Media Guide 2001. Huntington, WV: Chapman Printing.

Henschen, K. \& Fry, D. (1984). An archival study of the relationship of intercollegiate athletic participation and graduation. Sociology of Sport Journal, 1, 52-56.

Hinkle, D., Weirsma, W., \& Jurs, S. (1998). Applied Statistics for the Behavioral Sciences $4^{\text {th }}$ Edition). Boston: Houghton Mifflin Company.

Hood, A., Craig, A. \& Ferguson, B. (1992). The impact of athletics, part-time employment, and other activities on academic achievement. Journal of College Student Development, 33, 447-453.

Howard-Hamilton, M. \& Watt, S. (2001). Student services for athletes. New Directions for Student Services, 93, 1-7.

Jacobson, J. (2001). A study financed by the College Board bolsters reliability of the SAT. The Chronicle of Higher Education. Retrieved on April 27, 2001 from http://www.chronicle.com.

Jankowski, J. (1999). Graduation rates steady for scholarship athletes. The National Collegiate Athletic Association News Release. 1-3.

Johnson, B. and Christensen, L. (2000). Educational research: Quantitative and qualitative approaches. Boston: Allyn and Bacon.

Johnson, D.M., (1996). Science credit for agriculture: Relationship between perceived efforts and teacher support. Journal of Agricultural Education, 37(4), 9-17. 
Kennedy, S., \& Dimrick, K., (1987). Career maturity and professional sports expectations of college football and basketball players. Journal of College Student Personnel, 28, 293297.

Kerlinger, F. N. (1986). Foundations of Behavioral Research ( $3^{\text {rd }}$ ed.). Fort Worth, TX: Holt, Reinhart \& Winston.

Klein, S. \& Bell, R. (1993). How will the NCAAs new standards affect minority student athletes. Chance, 8(3), 18-21.

Kirk, W. \& Kirk S. (Eds.). (1993). Student athletes: shattering the myths and sharing the realities. Alexandria, VA: American Counseling Association.

Kneller, G. (1965). Educational anthropology. New York. Wiley.

Knight, John S. \& James L. (1991, 1993). Reports of the knight foundation commission on intercollegiate athletics. Charlotte, NC: W.C. Friday.

Lapchick, R. \& Slaughter, J. (1989). The rules of the game: Ethics in college sport. New York: Collier MacMillian Publishers.

Lapchick, R. (1989). Pass to play: student athletes and academics. Washington, D.C.: National Education Association.

Lederman, D. (1991). Officials criticized for athlete's low graduation rates. The Chronicle of Higher Education. Retrieved on September 21, 1999 from http://www.chronicle.com.

Lederman, D. (1992). Academically deficient athletes get some help. The Chronicle of Higher Education. Retrieved on September 22, 1999 from http://www.chronicle.com.

Leonard, W. (1985). Exploitation in college sport: The views of basketball players in NCAA I, II, III. Journal of Sport Behavior, 9(1), 11-30. 
Lewis, J. (1999). Cureton: The baton passes to the third circuit court of appeals. Holland and Knight, LLP. Sports Law Letter, 2(3), 3.

Lorimer, M. (1972). The study of persistence and performance of first time freshman admitted on criteria other than high school GPA's and test scores. East Lansing: Michigan State University, Office of Institutional Research.

Low achievers improve reading skills, but top students lose ground in math and science (1993). National Assessment of Academic Progress, 16.

Maloney, M. \& McCormick, R. (1992). An examination of the role that intercollegiate athletics participation plays in academic achievement: Athletes feats in the classroom. Journal of Human Resources, 28, 3, 555-570.

Martens, M.P. \& Lee F.K. (1998). Promoting the life-career development in the student athlete. How career centers can help. Journal of Career Development, 25, 123-134.

Mayo, A. (1982). The relationship between athletic participation and athletic aptitude. Achievement and progress of male and female athletes in revenue and non-revenue producing sports at The Ohio State University. Unpublished doctoral dissertation, Ohio State University. Retrieved September 17, 2001 from http://www.google.com.

Messer, J. \& Cherry, M. (2000, August 18). Players given chance to succeed. WVU and Marshall find some academic diamonds in the rough. The Charleston Daily Mail. Retrieved on August 19, 2000 from http://www.dailymail.com.

McMillen, T. (1992). Out of Bounds: How the American sports establishment is being driven by greed and hypocrisy-and what needs to be done about it. New York: Simon and Schuster. Michener, J. (1976). Sports in America. New York. Random House. 
Miller, L. (1995). New NCAA rules may bench some athletes. Education Week. Retrieved on September 22, 1999 from http://www.edweek.org.

National Collegiate Athletic Association Division I Manual (1 ${ }^{\text {st }}$ ed.). (1983). Mission, KN:

National Collegiate Athletic Association.

National Collegiate Athletic Association Division I Manual ( $1^{\text {st }}$ ed.). (1996). Overland Park, KN:

National Collegiate Athletic Association.

National Collegiate Athletic Association Division I Manual ( ${ }^{\text {st }}$ ed). (1999). Overland Park, KN:

National Collegiate Athletic Association.

National Collegiate Athletic Association Division I Manual ( $1^{\text {st }}$ ed.). (2000). Indianapolis, IN:

National Collegiate Athletic Association.

National Collegiate Athletic Association Division I Manual (1 ${ }^{\text {st }}$ ed.). (2001). Indianapolis, IN:

National Collegiate Athletic Association.

Naughton, J. (1996). Report finds lagging graduation rates among basketball players. The

Chronicle of Higher Education. Retrieved on September 22, 1999 from http://www.chronicle.com.

Naughton, J. (1997). Athletes lack grades and test scores of other students. Critics of big time sports say that the gap at many division I universities is too high. The Chronicle of Higher Education. Retrieved on September 22, 1999 from http://www.chronicle.com.

Naughton, J. (1997). U of North Carolina is proud of its balance of big time athletics and quality academics. The Chronicle of Higher Education. Retrieved on September 21, 1999 from http://www.chronicle.com. 
Nettles, M., Theony, A. \& Gosman, E. (1986). Comparative and predicative analysis of black and white students college achievement and experiences. Journal of Higher Education, 57, 289-318.

Nikou, N. \& Dinardo, B. (1985). Academics vs. athletics: Are the pressures too great? Journal of Physical Education, Recreation, and Dance, 56(8), 72-73.

Nyquist, E. (1979). Wine, women, and money: College athletics today and tomorrow. Educational Review, 60, 376-393.

Odenkirk, J. (1981). Intercollegiate athletics: Big business or sport? Academe, 67, 62-66.

Ogilvie, B. \& Tutko, T. (1971). Sports: If you want to build character try something else. Psychology Today. 5, 61-63.

Oliver, H. (1995). Influence of motivational factors in performance. Journal of Instructional Psychology, 22(1), 45-49.

Padilla A., and Walker L. (1994). The battle for control of college sports. The Chronicle of Higher Education. Retrieved on September 22, 1999 from http://www.chronicle.com.

Panel says freshman standards are flawed. (1995). The Chronicle of Higher Education. Retrieved on September 23, 1999 from http://www.chronicle.com.

Pascarella, E. \& Smart, J. (1991). Impact of intercollegiate athletic participation for African American and Caucasian men: Some further evidence. Journal of College Student Development, 32, 123-130.

Pascarella, E., Bohr, L., Nora, A. \& Terenzini, P. (1995). Intercollegiate athletic participation and freshman year cognitive outcomes. Journal of Higher Education, 66, 369-387.

Person, D., Benson-Quaziena, M. \& Rogers, M. (2001). Female student athletes and athletes of color. New Directions for Student Services: Student Services for Athletes, 93, 53-64. 
Petrie T.A., and Russell, R.K. (1995). Academic and psychosocial antecedents of academic performance for minority and non-minority college football players. Journal of Counseling and Development, 73, 615-620.

Prentice, T. (1997). The student athlete. Paper presented at the $250^{\text {th }}$ Anniversary Symposium on the Student Athlete, Princeton, NJ.

Publication manual of the American Psychological Association (5 ${ }^{\text {th }}$ ed.). Washington DC: American Psychological Association.

Purdy, D. (1981). Educational attainment and collegiate athletes: Intra-group analysis and comparison to the general student population. Paper presented at the Annual Meeting of the American Alliance for Health, Physical Education, Recreation, and Dance, Boston, MA. (ERIC Document Reproduction Service No. ED202844).

Purdy, D., Eitzen, D.S., and Hufnagel, R. (1982). Are athletes also students? The educational attainments of college athletes. Social Problems, 29(4), 439-448.

Ratzburg, W. (1999). Organizational behavior and the expectation. Retrieved on March 102001 from http://www.geocites.com/Athens/Form.

Reith, K. (1995). Student athletes continuing to graduate at a higher rate. National Collegiate Athletic Association News Release. 1-4.

Report of the McIntosh Commission on fair play in student athlete admissions. (1994). ISAR, Retrieved on September 21, 1999 from http://www.ferris.edu.

Reyes, N. (1997, Feb. 20). Holding on to what they have got. Black Issues in Higher Education, $13,36-41$. 
Richards, S. \& Aries, E. (1999, May/June). The division III student athlete: Academic performance, campus involvement, and growth. Journal of College Student Development, $40(3), 211-217$.

Richards, J., Holland, J., and Lutz, S. (1966). The prediction of student accomplishment in college. (ACT Research Reports, No.13). Iowa City, IA: American College Testing Program.

Richards, J. \& Lutz, S. (1967). Predicting student accomplishment in college from the act assessment. (ACT Research Reports, No. 21). Iowa City, IA: American College Testing Program.

Rooney, C. (1999). Decision shows test scores do not measure merit. Fairtest Press Release. 3034.

Ryan, R.J. (1989). Participation in intercollegiate athletics: Affective outcomes. Journal of College Student Development, 30, 122-128.

Sack, A. \& Thiel, R. (1979). College football and social mobility: A case study of Notre Dame football players. Sociology of Education, 52,_60-66.

Sack, A. \& Thiel, R. (1985). College basketball and role conflict: A national survey. Sociology of Sport Journal, 2, 195-209.

Sack, A. \& Staurowsky, E. (1998). College athletes for hire. The evolution and legacy of the NCAAs amateur myth. Westport, CT: Praeger Publishers.

Shulman, J. \& Bowen, W. (2001). College sports and educational values. The game of life. Princeton, NJ: Princeton University Press. 
Sedlacek, W. \& Adams-Gaston, J. (1992). Predicting the academic success of student athletes using the SAT and non-cognitive variables. Journal of Counseling and Development, 16, $171-178$.

Sedlacek, W. (1996). Employing non-cognitive variables in admitting students of color. New Directions for Student Services, 74, 79-81.

Sellers, R., Kuperminc, G.P., \& Waddell, A.S., (1991). Life experiences of African American student athletes in revenue producing sports; A descriptive empirical analysis. Academic Athletic Journal, 21-38.

Sellers, R. \& Chavous, T. (1997). Motivation vs. structure: Factors in the academic performance of African American college athletes. African American Research Perspectives, 3(1), $12-$ 20.

Shapiro, B. (1984). Intercollegiate athletic participation and academic achievement: A case study of Michigan State University student athletes. Sociology of Sport Journal, 1, 46-51.

Simons, H., Van Rheenen, D. \& Covington, M. (1999). Academic motivation and the student athlete. Journal of College Student Development, 40(2), 151-162.

Snyder, P. (1996). Comparative levels of expressed academic motivation among Anglo and African American university student athletes. Journal of Black Studies, 26(1), 651-667.

Sowa, C., Thomson, M. \& Bennett, C. (1989). Prediction and improvement of academic performance for high risk black college students. Journal of Multi-Cultural Counseling and Development, 17, 14-22.

Sperber, M. (1990). College sports, inc.: The athletic department vs. the university. New York: Henry Holt and Company. 
Sperber, M. (1998). Onward to victory: the crises that shaped college sports. New York: Henry Holt and Company.

Spivey, D. \& Jones, T. (1975). Intercollegiate athletic servitude: A case study of the black Illinois student athletes, 1931-1967. Social Science Quarterly, 55, 939-947.

Steeh, C. (1981). Trends in nonresponse rates. Public Opinion Quarterly, 45, 40-57.

Stier, W. Jr. (1992). The TRIAD, assisting, advising, and assessment model: One institutions attempt to support the student athlete. Academic Athletic Journal, 6, 34-42.

Stone, J. \& Strange, C. (1989). Quality of student experiences of freshman intercollegiate athletes. Journal of College Student Development, 30, 148-154.

Street, J.M. (2000). Self-efficacy: a tool for providing effective support services for student athletes. In S. Robinson (ed.), Gaining the competitive edge: Enriching the experience of the new student athlete. Columbia: National Resource Center for the First Year Experience and Students in Transition, University of South Carolina.

Stuart, D. (1985). Academic preparation and subsequent performance of intercollegiate football players. Journal of College Student Personnel, 26, 124-129.

Study shows academic profiles of incoming classes on upswing. (2001, July 16). NCAA News, pp. A1 \& A14.

Suggs, W. (1999). NCAA considers ideas to improve athlete's academic performance. The Chronicle of Higher Education. Retrieved on September 21, 1999 from http://www.chronicle.com.

Suggs, W. (1999). Scandals force colleges to reassess roles of academic advisors for athletes. The Chronicle of Higher Education. Retrieved on January 17, 2000 from http://www.chronicle.com. 
Suggs, W. (1999). NCAA says it can show direct link in athletes test scores and graduation rates. Institutions Institute for the Study of Academic Racism._. Retrieved on July 24, 1999 from http://www.ferris.edu/ISAR.

Suggs, W. (1999). Graduation rates hit lowest level in seven years for athletes in football and basketball. The Chronicle of Higher Education. Retrieved on September 10, 1999 from http://www.chronicle.com.

Suggs, W. (2001). Graduation rate for male basketball players falls to lowest level in a decade. The Chronicle of Higher Education. Retrieved September 22, 2001 from http://www.chronicle.com.

Summers, J. (Ed.). (1991). NCAA academic performance study (NCAA Research Report 90-01). Overland Park, KN: National Collegiate Athletic Association.

Taylor, D. (1995). A comparison of college athletic participants and non-participants on selfesteem. Journal of College Student Development, 36, 444-451.

Telander, R. (1996). The hundred yard lie: The corruption of college football and what we can do to stop it. Urbana: University of Illinois Press.

The crisis in intercollegiate athletics: A report by a panel of retired college presidents. (1990). The Chronicle of Higher Education. Retrieved on September 21, 1999 from http://www.chronicle.com.

The FERPA Answer Book for Higher Education Professionals. (2000). Horsham, PA: LRP Publications.

The student athlete right to know and campus security act. House of Representatives, $101^{\text {st }}$ Congress, $2 d$ Session. (1991). (Report No. House-R-101-518). Washington DC: House 
Committee on Education and Labor. (ERIC Document Reproduction Service No. ED323840).

Thelin, J. \& Wiseman, L. (1989). The old college try: Balancing academics and athletics in higher education (ASHE-ERIC Higher Education Report 4, 1989).Washington, DC: School of Education and Human Development, The George Washington University.

Ting, S. \& Robinson, T. (1998). First year academic success: A prediction combining cognitive and psychosocial variables for Caucasian and African American students. Journal of College Student Development, 39(6), 599-610.

Tinto, V. (1987). Rethinking the causes and cures of student attrition. University of Chicago Press: Chicago.

Tracey, T. \& Sedlacek, W. (1984). Non-cognitive variables academic success by race. Management and Evaluation in Guidance, 16, 171-178.

Tracey, T. \& Sedlacek, W. (1985). The relationship of non-cognitive variables to academic success: A longitudinal comparison by race. Journal of College Student Personnel, 26, 410.

Tunis, J. (1958). The American way in sports. New York: Duell, Sloan, and Pierce. Underwood, C. (1984). The student athlete: eligibility and academic integrity. East Lansing, MI: Michigan State University Press.

Urban, R. (2000). Division II and III-First rate opportunities: Athletes find success at colleges in lower athletic divisions. Real Sports, 62-63.

USC confesses massive athletic abuses. (1980, October 17). Higher Education Daily, 3. Vroom, V.H. (1964). Work and Motivation. New York: John Wiley and Sons. 
Walter, T., Smith, D., Huey, G., Wilhelm, R., \& Miller, S. (1987). Predicting the academic success of college athletes. Research Quarterly for Exercise and Sport, 58, 273-279.

Watt, S. and Moore, J. (2001, Spring). Who are student athletes? New Directions for Student Services, 93, 7-18.

Webb, H. (1968). Social backgrounds of college athletes. Paper presented at the Annual Meeting of the American Alliance for Health, Physical Education, and Recreation, St. Louis, MO.

White, K. (1998, February 11). Minority students hit hardest by stricter eligibility rules. Education Week, Retrieved on September 21 from http://www.edweek.org.

Wilson, K. (1967). The big ten. Englewood Cliffs, NJ: Prentice-Hall.

Witham, D. (1995). High school courses may be prospective athletes' biggest hurdle. The Chronicle of Higher Education. Retrieved on September 22, 1999 on http://www.chronicle.com.

Who can play? An examination of NCAAs proposition 16. (1995, August). National Center for Education Statistics. Retrieved on September 21, 1999 from http://nces.ed.gov/pubs/95763.html.

Wyatt, J. (1999). Our moral duty to clean up college athletics. The Chronicle of Higher Education, 45, A56.

Young, B. \& Sowa, C. (1992). Predictors of success for black student athletes. Journal of College Student Development, 33, 318-324.

Zimbalist, A. (1999). Unpaid professionals: Commercialism and conflict in big time sports. Princeton, N.J.: Princeton University Press. 


\section{APPENDIX A}

NCAA Bylaw 5-1 (j)

ELIGIBILITY FOR PRACTICE AND COMPETITION. A student-athlete who enrolls in an Division I or II institution as an entering freshman with no previous full-time college attendance shall meet the following academic requirements, and any applicable institutional and conference regulations, to be considered a qualifier and thus be eligible for practice and competition during the first academic year in residence. (Athletically related financial aid restrictions were added in 1991 under Proposition 42).

QUALIFIER, BASIC REQUIREMENTS. A qualifier is defined as one who is a high school graduate and who presented the following academic qualifications

a. A minimum cumulative grade-point average of 2.0 (based on a maximum 4.0 scale) in a successfully completed core curriculum of at least 11 academic courses, including at least the following:

$\begin{array}{ll}\text { English } & 3 \text { years } \\ \text { Mathematics } & \text { 2 years } \\ \text { Social Science } & 2 \text { years } \\ \begin{array}{l}\text { Natural or } \\ \text { Physical Science } \\ \text { Two Additional }\end{array} & 2 \text { years (with lab in one course) } \\ \text { Core-Courses* } & 2 \text { years } \\ & \\ \text { *Foreign Language, Non-Doctrinal Religion } \\ \text { or another two from the above listed areas }\end{array}$

This record must be then certified on the official high school transcript combined with a minimum 700 combined score on the SAT verbal and math sections or a minimum 18 composite on the ACT. All of the test criteria must be met under normal conditions on a national testing date and site (NCAA, 1983) 


\section{APPENDIX B}

NCAA Bylaw 14.3

14.3.1 Eligibility for Financial Aid, Practice, and Competition. A student athlete who enrolls at a member institution with no previous full-time college attendance shall meet the following academic requirements, as certified by an initial eligibility clearinghouse approved by the Executive Committee, and any applicable institutional and conference regulations to be considered a qualifier and thus be eligible for financial aid, practice and competition during the first academic year in residence.

14.3.1.1 Qualifier. A qualifier is defined as one who is a high school graduate and who presented the following academic qualifications.

(a) A minimum cumulative grade point average as specified in the initial eligibility index, based on a maximum 4.0, in a successfully completed core curriculum of at least 13 academic core-courses including the following:

English

Math (Alg. 1 or higher)

Natural or Physical Science (including lab)

Additional course in English, Math, Science

Social Science

Additional Academic Courses

In any of the above areas and foreign language,

Computer science, philosophy, non-doctrinal

Religion
4 years

2 years

2 years

1 year

2 years

2 years

(b) A minimum combined score on the SAT verbal and math sections or a minimum sum score on the ACT. The required SAT or ACT score must be achieved under national testing conditions on a national testing date. 
14.3.1.1.1 Initial Eligibility Index. Freshman may establish eligibility as a qualifier using the following initial eligibility index:

\section{Core GPA}

2.5 and above

2.475

2.450

2.425

2.400

2.375

2.350

2.325

2.300

2.275

2.250

2.225

2.200

2.175

2.150

2.125

2.100

2.075

2.050

2.025

2.000
SAT

820

830

840-850

860

860

870

880

890

900

910

920

930

940

950

960

960

970

980

990

1000

1010

\section{Sum ACT}

68

69

70

70

71

72

73

74

75

76

77

78

79

80

80

81

82

83

84

85

86

14.3.2.1 Partial Qualifier. A partial qualifier is a student who does not meet the requirements for a qualifier but who, at the time of graduation from high school, presents the following core curriculum GPA and the corresponding ACT or SAT score (NCAA, 2001):

\section{Core GPA}

2.750 and above

2.725

2.700

2.675

2.650

2.625

2.600

2.575

2.550

2.525
SAT

720

730

730

740-750

760

770

780

790

800

810

\section{Sum ACT}

59

59

60

61

62

63

64

65

66

67 


\section{APPENDIX C \\ Jury of Experts for Readibility of Survey Instrument}

Michelle Duncan, Director of the Buck Harless Student Athlete Program, Marshall University.

Jim Hodge, Math Faculty, Mountain State University, Beckley, West Virginia

Karen Kirtley, Director of Auxiliary Operations, Marshall University

Paul Leary, Ed.D., Professor Leadership Studies, Marshall University

Robin Walton, Associate Professor, College of Nursing and Health Professions, Marshall

University

Rhonda Shepherd, Director of the Testing and Tutoring Center, Mountain State University,

Beckley, West Virginia

Doug Sturgeon, Director of Student Teaching, Rio Grande College, Gallipolis, Ohio

Darrell Taylor, Director of Upward Bound, Concord College, Concord, West Virginia 


\section{APPENDIX D}

INTERCOLLEGIATE ATHLETIC GRADUATION SURVEY MID-AMERICAN CONFERENCE

Please check and/or answer as accurately as you can.

\section{DEMOGRAPHIC INFORMATION}

1. What is your gender?

2. What is your ethnicity?

3. What is your academic standing?

4. Do you expect to graduate?

5. What is your expected graduation date (Month/Year)?

6. What is your college major?

7. What sport or sports have you participated in?

8. Did you receive an athletic scholarship for at least one academic year?

9. What was your entrance exam score (One or both)?

10. What was your high school Core-Course GPA determined by the NCAA Clearinghouse?

11. What is your current grade point average in college?
Male Female

African American (Black) Asian/Pacific Islander Caucasian (white) Hispanic Other

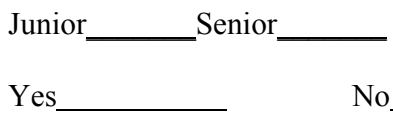

Main Other.

Yes

No

ACT

SAT

Please circle best choice below.

\section{GENERAL ISSUES}

12. My coach emphasized academics more than athletics during the recruiting process.

13. The coach made it clear to me about academics being more important than athletics during the recruiting process.

14. During college, my coaches placed academic success above athletic success.

15. My coach punishes me for not attending class.

16. My coach cares that I succeed academically and graduate.

17. It is important to me for my coach to encourage and require good performance in class.

18. If I fail academically, my coaches try to find a legitimate way to keep me eligible

19. My coach stresses the importance of getting a college degree.
AGREE NEUTRAL DISAGREE

1 2

123

123

1

$2 \quad 3$

1

2

3

1

2

3

1 
20. When I entered college, getting a degree was more important than being a professional athlete.

AGREE NEUTRAL DISAGREE

21. My coach is assisting me in meeting my professional sports goals.

22. My coach is more concerned with my graduation than for my eligibility to play.

23. I believe my coach will be interested in my academic success when my eligibility expires.

24. It is of great importance to me to get a college degree.

25. I feel I have control over my academic and athletic life.

26. I chose this school because of the coach.

27. My coach is the person who has the most academic influence on me.

28. It is important to my coach for me to graduate.

29. My sport does not interfere with my academic success.

30. I routinely practice no more than 20 hours per week.

31. I spend at least 10 hours studying per week.

32. I was redshirted in college.

33. The importance of academics was stressed in high school.

\begin{tabular}{|c|c|}
\hline 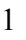 & 2 \\
\hline 1 & 2 \\
\hline 1 & 2 \\
\hline 1 & 2 \\
\hline 1 & 2 \\
\hline 1 & 2 \\
\hline 1 & 2 \\
\hline 1 & 2 \\
\hline 1 & 2 \\
\hline 1 & 2 \\
\hline 1 & 2 \\
\hline 1 & 2 \\
\hline 1 & 2 \\
\hline 1 & 2 \\
\hline
\end{tabular}

34. I knew I had to meet minimum academic standards to compete in intercollegiate athletics.

3 3

35. I feel that I get special treatment because I am a student athlete.

36. I do not feel discriminated against because I am a student athlete.

37. I am regarded as a serious student by my professors/instructors.

38. Academics are my top priority in college.

39. I am satisfied with my athletic performance.

40. I chose this school because of its athletic reputation in my sport.

41. I have worked a job while enrolled in college and participated in athletics.

42. I have(check all that apply):

ATTENDED SUMMER SCHOOL TO REMAIN ELIGIBLE ATTENDED SUMMER SCHOOL TO GRADUATE FASTER REPEATED COURSES

BEEN ON ACADEMIC PROBATION

FOUND COURSES TOO DIFFICULT

RECEIVED AN INCOMPLETE AT LEAST ONCE 
AGREE NEUTRAL DISAGREE

43. I use special academic support services for student athletes on a regular basis.

44. Please check the services you use: ADVISEMENT/REGISTRATION TUTORIAL ASSISTANCE MENTORING COMPUTER LAB STUDY HALL STUDY SKILLS LEARNING DISABLED SERVICES

45. I could not graduate without having used these services.

46. I do not need these services to graduate.

47. My coaches require me to use these services.

48. I use these services voluntarily.

49. The academic support staff stresses academic success above athletic success.

50. I feel academics are important and a degree is needed for me to be a success.

51. I am taking the major that I chose when I entered college.

52. I have changed my major to remain eligible.

53. I can choose the courses that I want to take.

54. I plan to pursue a Master's/Ph.D. degree in the future.

55. I chose this school to meet my academic goals.

56. The athletic academic advisors have the most academic influence over me.
1

1

1

1

1

1

1

1

1

1

1

1
3

3

3

3

3

3

3

3

3

3

3

3

Please add any comments you desire in the space below. 


\section{BRADLEY DAVID RIDPATH}

209 West 9th Avenue

Huntington, WV 25701

(304) 529-6235

ridpath@marshall.edu
Judicial Affairs

Marshall University

Huntington, WV 25715

(304) 696-2495
OBJECTIVE

$\underline{\text { EDUCATION }}$

\section{Division I-A Athletic Director}

Ed.D. Doctor of Education in Higher Education Administration.West Virginia University, Morgantown, West Virginia, 1998-Present.

Dissertation Title: "NCAA Division I Student Athlete Characteristics as Indicators of Academic Achievement and Graduation from College.

MSA, Masters of Sports Administration, Ohio University, Athens, Ohio, 1995

BA, Bachelor of Arts, Speech Communication, Colorado State University, Fort Collins, Colorado,1990.

PROFESSIONAL $\underline{\text { SUMMARY }}$
PROFESSIONAL EXPERIENCE

Oct. 01-Present

Nov. 97-Oct. 01
More than seventeen years of management, operational, marketing, fund raising, and teaching experience in small and large diversified organizations. Ability to work with many of today's most widely used computer programs. Proficient in all types of writing to include informational and technical. Possess relevant higher education experience in fund raising and marketing, capital improvements, budget management, compliance, media relations, operations, and facility management. Understand the full breadth and depth of higher education issues and governance.

DIRECTOR OF JUDICIAL PROGRAMS. Marshall University, Huntington, West Virginia. Plan, coordinate, and direct institution-wide implementation and enforcement of the Marshall University Student Code of Conduct, the Residence Hall Judicial Process, and the student judicial system. Adjunct Faculty Member, Exercise and Sport Science

ASSISTANT ATHLETIC DIRECTOR, COMPLIANCE AND STUDENT SERVICES. Marshall University, Huntington, West Virginia. Coordinated, directed, and educated coaches, more than 400 studentathletes, and representatives of athletics interests of 16 varsity sports. 
Sept. 95 -Nov. 97

June 95-Jan. 96

May 94-June 95

Sept. 93-May 94

May 90-Sept. 93

Aug. 89 - May 90

Mar. 88 - May 90

Mar. 88 - Mar. 90
DIRECTOR OF ATHLETIC COMPLIANCE/EVENT AND FACILITIES MANAGER. Weber State University, Ogden, Utah. Coordinated a revamped institutional compliance program. Directed and ensured compliance with all NCAA and Big Sky Conference rules and regulations for 15 intercollegiate sports, consisting of more than 250 student-athletes and staff.

\section{ASSISTANT DIRECTOR OF MARKETING AND FUND RAISING.} Weber State University, Ogden, Utah. Assistant director of a comprehensive athletics marketing and promotions program. Involved in all facets of department marketing and fundraising plan to include annual, planned, and corporate giving.

ASSISTANT WRESTLING COACH. Ohio University, Athens, Ohio. Full-time coach for a nationally ranked team. Chaired annual fund raising drive for wrestling scholarships. Managed many recruiting, eligibility, financial aid, and budget management functions for team relating to NCAA compliance.

UNIT MANAGER. Pepsico Corporation, Florida Island Foods, Augusta, Georgia. Managed a high-volume restaurant in a community of more than 100,000 people. Supervised a crew of 15 people on a daily basis designed to provide customer service and satisfaction in a 24-hour operation.

EXECUTIVE OFFICER. United States Army. Schweinfurt, Germany. Managed a fleet of 80 tactical vehicles in a military organization. Developed a written maintenance plan to ensure the improved efficiency and quality of all vehicles and associated equipment. Planned and organized the military training for a 4000 member organization to include the allocation of logistics, resources, and a 4.5 million dollar budget.

TELEVISION SPORTS REPORTER. Columbine Cablevision, Fort Collins, Colorado. Assistant sports reporter for a small market television news show.

UNIT COMMANDER. Colorado Army National Guard, Denver, Colorado. Directed a 65-person military organization, including all associated equipment.

SPORTSWRITER. Rocky Mountain Collegian, Colorado State University, Fort Collins, Colorado. Assisted in supervising a staff of six in producing a daily sports section for a large university newspaper with a circulation of 30,000 . 


\section{$\underline{\text { PROFESSIONAL HIGHLIGHTS }}$}

US Army Enlisted, Communications Operator, Germany, 1983-1986

Certified International, Collegiate, and High School Wrestling Official, 1983-Present

Member, TVU Unterderrbach, Germany, Club Wrestling Team, 1984-86

Member, All-Army European Wrestling Team, VII Corps, 1985-1986

Athletic Media Relations Volunteer, Augusta State College, Georgia, 1993-94

Contributing Editor and Writer, Fort Collins Fitness Magazine, 1988-90

\section{$\underline{\text { AWARDS AND HONORS }}$}

Region Commanders Leadership Award, Army ROTC, Colorado State University, 1986 Honor Graduate, Army ROTC Advanced Camp, Fort Lewis, WA, 1986

ROTC Distinguished Military Student, Colorado State University, 1986-1990

ROTC Distinguished Military Graduate, Colorado State University, 1990

Dr. James A. Lavery Scholarship Award Winner, Ohio University, 1995

\section{COMMITTEES AND PROFESSIONAL AFFILIATIONS}

National Wrestling Coaches Association Member, 1994-Present

Member, Weber State University Development Council, 1995-96

Chair, Mrs. J.E. Thackrey Memorial Scholarship Fund, Ohio University, 1996-Present

Member, National Association of Collegiate Directors of Athletics, 1995-Present

Member, National Association of Collegiate Compliance Coordinators, 1998-Present

Tau Kappa Epsilon Fraternity, Faculty Advisor and Honorary Member, 1999-Present

Member, Omicron Delta Kappa, Honors Fraternity, 2002-Present

Member, Association of Student Judicial Affairs, 2001-Present

\section{$\underline{\text { PRESENTATIONS }}$}

Guest Presenter, "Institutional, Non-Profit, and Educational Promotions." NCAA

Regional Compliance Seminar, Washington DC, May 2001

Compliance, "Being the Bad Guy." NCAA Regional Compliance Seminar, Orlando, Florida, May 2000

Title IX, Opportunities for Female Athletes or Extinction for Male Athletes. Weber State University Panel Presentation, April 1997

"What Exactly is the NCAA?" Weber State University Panel Presentation, November 1996

\section{$\underline{\text { PUBLICATIONS }}$}

Over 100 sports and feature articles for various media publications. 